\title{
590.7 C69a
}

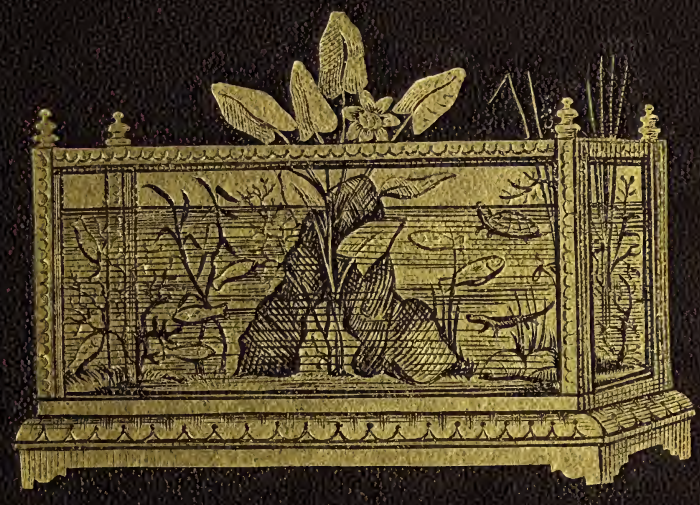




\section{THE UNIVERSITY \\ OF ILLINOIS}

\section{LIBRARY}

From the collection of Julius Doerner, Chicago Purchased, 1918.

$$
\begin{aligned}
& 590.7 \\
& \text { C69a }
\end{aligned}
$$


Return this book on or before the Latest Date stamped below. A charge is made on all overdue books.

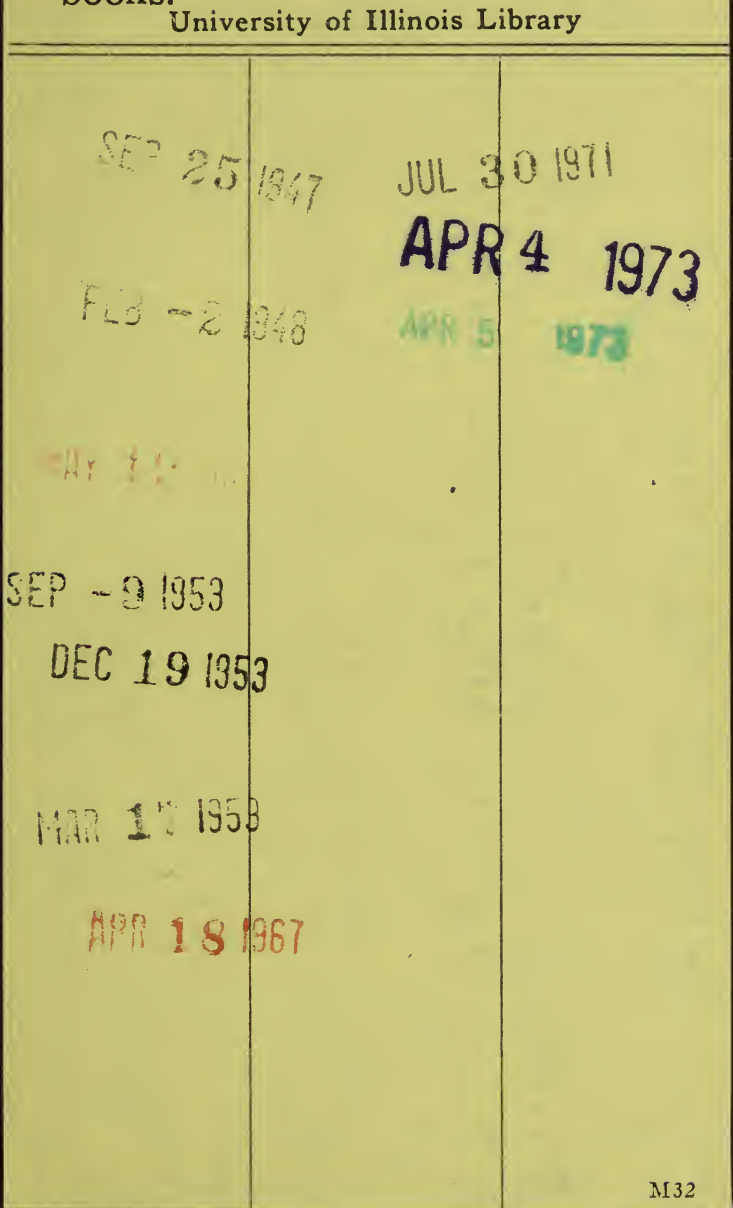


thene. w/10/1 = o/f

$75 \%$ 


\section{Digitized by the Internet Archive}

in 2016 with funding from

University of Illinois Urbana-Champaign Alternates

https://archive.org/details/americanparloraq00coll 



\section{AMERICAN PARLOR AQUARIUM,}

OR

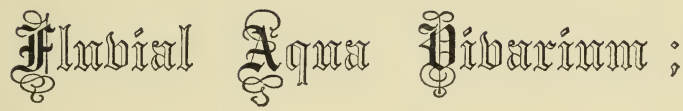

BEING A FAMTLIAR TREATISE ON THE FRESH WATER AQUARIUM; THE BEST MODE OF CONSTRUCTION AND ARRANGEMENT; INCLUDING A BRIEF SKETCH OF ALL THE FRESH WATER FISHES AND AQUATIC PLANTS ADAPTED TO THE SAME, FOUND IN THE UNITED STATES.

BY

J. H. COLLIER AND J. HOOPER.

NEW YORK :

JOHN H. COllier, Publisher, 78 Fulton Street. 1866. 
ENTERed according to Act of Congress, in the year 1866, by J. H. COLLIER,

In the Clerk's Office of the District Court of the United States, for the Southern District of New York.

P. EOKLER, Printer, 40 Fulton Street, N. Y. Lovejox \& Sos, Electrotypers, and Stereotypers, 15 Vandewater Street, N. Y. 


\section{7 \\ $\mathrm{C} 69 \mathrm{a}$}

\section{P R E F A C E.}

Tre want of a familiar treatise on the Parlor Aquarium, adapted to this country, has long been felt by all who have interested themselves in any way in this comparatively new science. Several English works are extant, but their local character does not suit our wants. In fact the American Aquarist is without a text book or guide, if we except the work of Mr. Henry D. Butler, which however is almost exclúsively devoted to the Marine Aquarium. The limited knowledge of our Fluvial Fishes and Plants, amongst all classes, and the evident want of a simple guide or text book, by those who feel any interest in the subject, are reasons which the author deems sufficient in offering this little book to the public.

The author has endeavored to simplify his style as much as possible, so as to render the work readable to those unacquainted with the technical terms of science. As however a few of those terms had necessarily to be used, to convey the required meaning, a brief glossary of the same is appended at the end of the work.

JOHN H. COLLIER. 



\section{INTRODUCTION.}

"Oh Nature! all sufficient! over all!

Enrich me with a knowledge of thy works !"

Trie study of any of Nature's works is one of the most ennobling pursuits that can engage the attention of mankind. It carries with it a sublimity of thought far higher than that derived from any other source; its effects are seen in the poet's pen, the painter's pencil, and the sculptor's chisel, and tends to elevate the soul of man from the grovelling pursuits of every day life, to that higher power, whose wisdom, goodness and divine works are seen on every hand, from the tiny dew-drop to the mighty cataract, and from the smallest thing that creeps upon the earth, to the noble lion that roams the desert wilds feared by all.

The study of Aquatic Natural History had been neglected more than any other, especially prior to the introduction of the Aquarium. The Botanical part is surrounded with difficulties in the procurement of specimens, and less is consequently known of it than any other branch of Botany. All the species being more or less submerged, they are collected with difficulty, and but very few have as yet been popularized to the Aquarium; one of my main objects is to point out and clearly describe all our native Aquatic Plants, suitable to the fluvial tank. 
Our Ichthyology, or history of fishes, is as yet in its infancy, no popular work has yet appeared, descriptive of them, so that we have groped our way as it were in the dark. Few species only are generally known, the few familiar ones being confined to those varieties whose capture is a sport, or a remunerative employment.

But the Aquarium opened a path to a field of science hitherto trod by few of "Nature's votaries;" it enkindled within the minds of many a desire to become better acquainted with the "life that moves beneath the waters." The gems of Nature's handiwork enshrined beneath the sparkling wave, and hidden deep in its carernous depths were almost wholly unexplored, their beauties, habits and peculiar formation were to us a sealed book. Little did we dream that at the depth of hundreds of fathoms, the waters teemed with life, that Anemones or Animal Flowers existed there rivalling in brilliancy of coloring, or delicacy of marking any of Nature's terrestrial gems. It had always been considered a fact that below a certain depth, animal life ceased to exist; to contravene this we have the testimony of the scientific officers who surveyed the Atlantic plateau for the ocean cable, who conclusively established the fact of animal and vegetable life existing at even the greatest depths. Our friend Capt. J. H. Mortimer of Savannah, an enthusiast in marine mollusca, has dredged many 'curiosities to science some of which were from the greatest depths he was enabled to fathom. 


\section{CONTENTS.}

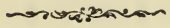

\section{CHAP'TER I.}

Discovery and History of the Science-Its first establishment in London-Its progress and ultimate introduction in the United States.

\section{CHAPTER II.}

The Principle of the Aquarium-Natural laws governing the same. Artificial æration a success. . . . . . . . 14

\section{CHAPTER III.}

The construction of the Aquarium Tank-The materials best suited for it-Proportions of a tank, and best shape for the same. 18

\section{CHAPTER IV.}

'The best location for an Aquarium-Effects of light and heat-The only perfect plan-Effects of light upon fish. . . . 21

\section{CHAPTER V.}

Arrangement of the Aquarium-Rockwork, how arranged-Instructions as to its proper arrangement-Effect produced upon fish by. long confinement without food-Food a necessity for their preservation and heaith-Diseases incidental to fish. 
viii

CONTENTS.

\section{CHAPTER VI.}

Specific descriptions of the various species applicable to the Aquarium. - 31

\section{CHAPTER VII.}

The Amphibians suited to the Aquarium. . . . . 99

\section{CHAPTER VIII.}

Fluvial Shells and Insects adapted to the Tank-What Insects to avoid. . . . . . . . . . . 111

\section{CHAPTER IX.}

The Vegetation of the Aquarium-The plants best adapted to the same. . . . . . . . . . . 116

Glossary of Technical Terms used . . . . . . 136

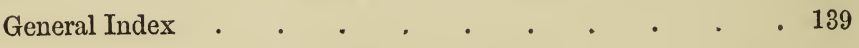

List of Illustrations $\quad . \quad$ • : . . $\quad$ • . . 144 


\section{FLUVIAL OR FRESH WATER AQUARIUM.}

\section{CHAPTER I.}

DISCOVERY AND EARLY HISTORY OF THE SCIENCE.

Discovery and History of the Science-Its first establishment in London-Its progress and ultimate introduction in the United States.

Finst, we must define our title. In this country it is known as the Aquaria when in the plural number, and Aquarium in the singular. Throughout Great Britain and the continent of Europe it is called the Aqua-Vivarium : this name is correct for the following reasons. Amongst the ancient Romans an Aquarium was simply a reservoir or large vessel for holding water, without regard to the uses to which that water was applied. A collection of living animals or reptiles was called a Vivarium; in the earlier period of the discovery of our science, a name was required for it, and it was deemed essential to have one that would convey and embrace within itself a truthful meaning of the subject; and the term Aqua-Vivarium was adopted, the first, Aqua, signifying water, and the latter, Vivarium, animal life. Now as our name Aquarium means 
simply a ressel for holding water, regardless of the uses to which that water may be applied, it is conclusively proven that the English name is the best and only correct one. But as the term Aquarium has been so generally adopted in this country, it will be used in this work.

Undoubtedly the marine or salt water Aquarium presents to us a far greater variety of character, and a more diverse and extensive field of research, furnishing an infinite collection of animal and vegetable life, far greater than the fluvial or fiesh water. In fluvial waters we lack altogether those grotesque forms so often found in sea water; such as the IHippocampus or Sea Horse, the Holothuria or Sea Cucumber, the Asterias or Star Fish, the Syngnathus or Pipe Fish, the Serpulas, Actinias, and hundreds of others, possessing some remarkable strucţure and endless diversity of character. So also with the Marine plants or Algce; they likewise excel the fluvial ones or diversity of structure, and far exceed them in numbers, fembracing plants of every hue. But attractive as the marine Aquarium deservedly is, there exists a barrier to its popularity which cannot easily be removed, and debars its general use; I allude to the difficulties experienced in procuring pure sea water. Space forbids me to dwell upon the subject, as my province is to confine myself to the fluvial or fresh water Aquarium.

The principle of the Aquarium was slightly indicated by Priestly in the latter part of the last century. It remained in obscurity until 1778-9 when Ingenhaus more closely approached it, by giving publicity to the fact, that plants immersed in water when exposed to the action of light emit oxygen. In 1833 Daubeney slightly noticed it. Ward in 1837 made demonstrations of its practicability with distinct- 
ness; but Dr. Lankaster in 1841 established the first true Aquarium, by keeping Sticklebacks in a glass vessel, without a change of water, the same being oxygenated by means of the Valisneria spiralis. Warrington in 1850 elucidated it clearly and was the first to make it publicly known. Before the Royal Chemical Society of London he demonstrated the experiments made, and the principle established thereby: that the functions of plants assigned to them for the conversion of carbonic acid gas into oxygen, and the consequent necessity of their presence for the preservation of animal life, which would otherwise be poisoned by its own secretions, because of the quantity of carbonic acid thrown off. About this time an open air tank was established by accident in the Gardens of the Hampton Court Palace, London; which was afterwards described by Mr. Jesse, and at the time attracted considerable interest amongst men of science. In 1852 the first practical exemplification of the science was opened to the public in the Gardens of the Royal Zoological Society, Regents Park, London. And to such an extent has the Aquarium been popularized there, that one firm alone in London employs a large steam factory for the manufacture of tanks, and fourteen experienced men are exclusively engaged in collecting marine curiosities for the same, whilst numbers of others collect for the fluvial department. Large quantities of pure sea water is constantly kept on hand, which is regularly sold like milk by the quart or gallon. In this immense establishment can be purchased at almost any time any of the marine or fluvial objects suitable to the Aquarium. To show how far we are behind in this science, I would state, that at the present time there is not an establishment in New York, or even in the United States, where any of the marine objects suited to a salt water Aquarium can be procured. 
In 1842 Dr. Johnson whilst experimenting with a view to ascertain the true vegetable nature of corallines, dicovered the fact, that Marine Alqce cause sea-water to remain pure, for an unlimited period,- - as long as they are in a growing condition. This was the year following Dr. Lankaster's similar discovery in regard to fresh water; so that Dr. Johnson is entitled to the discovery of the principle of the Marine Aquarium, as Lankaster is of the Fluvial.

The first introduction of the Aquaria to the American public, was at the American Museum, New York. In 1856, fifteen years after the principle of the Aquarium was proven by Dr. Lankaster, and four years after the opening of the Regents Park Aquaria, Mr. P. T. Barnum introduced it to the American public. This well known and enterprising showman, always anxious to secure and introduce to the public every novelty money can procure, started to England, and with the aid of Mr. David Mitchell, at that time Secretary of the Royal Zoological Society of London, introduced this new and attractive feature of Natural History to the American public. And although he is deserving of praise for his exertions in so doing, it was not from any love of science, but simply to add a new feature to his popular place of amusement. Some months after this Messrs. Butler and Cutting established the Aquarial Gardens in Boston; it finally passed into Mr. Barnum's hands and was eventually discontinued.

Soon after various styles of parlor Aquariums were manufactured and sold in New York and Philadelphia and their popularity has steadily increased. Undonbtedly they would become much more popular if experienced men in the science were engaged in their manufacture and sale, for few of them know anything at all of the subject, or are acquainted in the 
least manner with the habits of our fish, or the peculiarities of our Aquatic plants, their knowledge being confined to the buying of Gold-fish by the hundred, and retailing them to their customers.

It is in the field this knowledge only can be obtained; on the banks of the laughing brook, on the bosom of the placid lake, and in the almost impenetrable swamp; it is there, studying nature's book, that we can gain a knowledge of the objects fitted for our miniature pond. There is another knowledge acquired, that which cannot be transmitted one to the other, the same mental power that guides the artizan in his mechanical skill, which experience alone can acquire.

" Remote from busy life's bewildered way, O'er all his heart shall taste and beauty sway ;

Free on the sunny slope, or winding shore

With hermit steps to wander and adore."-(Pleasures of Hope.) 


\section{- CHAPTER II.}

THE PRINCIPLE OF THE AQUARIUM,

The Principle of the Aquarium-Natural laws governing the same-Artificial aeration a success.

MANY persons think that a mere tank designed for the use of fish, etc., is an Aquarium; this is a popular error in this country. A tank manufactured for such a purpose, no matter what the material may be that is used in its construction, correctly speaking, is not an Aquarium, but an Aquarium tank. An Aquarium consisting of the tank and its contents. The true and perfect Aquarium should be self sustaining. The plants contained therein sufficiently numerous to liberate or throw off enough oxygen to furnish the living animals with life sustaining power, the fish and other animal life sufficient to consume that oxygen and repay the plants with enough carbon to sustain them. For this is the fundamental principle of nature both of animal and vegetable life; the animal portion being sustained by the oxygen generated by vegetation, and the vegetable part by the carbon exhaled by the animal. Consequently if too much animal life be placed in the tank, the want of sufficient oxygen is soon experienced by the finny inhabitants thereof, causing them to sicken and die; if too much vegetation exist therein, the water becomes over charged with oxygen, vitiating their systems with its enervating 
powers, so that the same fatal result necessarily follows. In the Aquarium the nearer we can arrive at an equalization of the two powers the nearer we approach perfection. But another point must be considered; it is not alone necessary that these two life sustaining powers should be equalized, because you may have too much of both, and in this case the health of your animal life is equally jeopardized. You may ask then, how are we to know? how are we to determine when enough of animal life and regetation is placed in the tank? This I answer is altogether a matter of experience. No rule can be adopted as to the quantity of the same: different species of fish exhaust more oxygen and supply more carbon, than others; so, too, with aquatic plants, some species liberate more oxygen and take up more carbon than others, and it is only by practical experience and a use of discretion, that enables us to determine the amount of animal and vegetable life sustainable in a given quantity of water. I know some have given advice as to the number of fish that could be sustained in a given quantity of water in a still tank, but it is of no value, for the reasons above given; besides which, the varied sizes of fish preclude any such rule. As a general circumstance persons crowd too much in their tanks, it is much cheaper and better to have a few fish in the Aquarium in good health, than to over crowd it, as is too often the case. In regard to the amount of oxygen and carbon, we see the same causes produce like effects even to mankind; in tropical climes, where vegetation arrives at its greatest luxuriance, the atmosphere is overcharged with oxygen, engendering malarious fevers: the vitality being quicker, the lives of mankind are shorter in the number of years, yet in one sense they live as long, because their temperaments are quickened. 
The Marine tanks of the American Museum, not being supplied with vegetable life, an excellent substitute has been adopted, which answers the purpose very well; that is, artificial acration, - air being forced through the water of the tanks by means of a bellows attached to an aerometer; this was introduced into this Aquaria by Messrs. Butler and Cutting, the former gentleman being for a lengthened period manager of the same.

My opinion based on experience in tanks artificially supplied with air is, that for a public Aquaria, where a number of tanks are kept, it is an excellent plan, but is not feasible for private purposes, as it is necessary the motive power should be continually in action. I find that fish kept in tanks so supplied, in a short time become acclimated to them, so that they but seldom come to the surface for air, such fish, changed as it were in their nature, soon die if removed from the aerated tank to one not so supplied. The effect of a stream of air passing upwards through the water of the tank is indeed beautiful, forming innumerable globules resembling quicksilver, which are continually and rapidly rising to the surface, these globules, containing the confined air, being so much lighter than water, causes them quickly to ascend.

As I remarked in the commencement of this chapter, that it is not generally understood what constitutes an Aquarium, I would say, that many people are in the habit of calling every vessel or tank wherein fish are placed, an Aquarium; this is not so, as an Aquarium is a tank or vessel, no matter of what material it may be composed, that contains animal and vegetable life self sustaining.

A good self supporting fluvial tank never requires a change of water; I have kept one eighteen months with the same water, 
the only water added during the time, being a sufficiency to make good the evaporation continually going on, and at all times the water was a hundred per cent. purer, brighter and cleare than the best filtered water. Water under such circumstances possesses a sparkling appearance, and no water, no matter how hard it may be or how much lime it naturally contains, if placed in an Aquarium fails to become soft as rain water, the plants absorbing the lime of the same. This absence of a requirement of a change of water is the desideratum attainable and to be striven for in the management of the Aquarium. It is the constant meddling with the tank, changing the water, the position of rocks and plants, the heaping in of bread, crackers, cake, etc., to the fish, why so many, yes! nearly all, fail in keeping their tanks healthy and clean. If by any cause any of your plants show signs of decay, or any of your fish die, they should be carefully removed as soon as possible, for if allowed to remain, they contaminate the water with noxious gasses, rendering a change of the same absolutely necessary. 


\section{CHAPTER III.}

TIE CONSTRUCTION OH THE AQUARIUM TANK.

The Construction of the Aquarium Tank-The materials best suited for it-Proportions of a Tank, and the best shape for the same.

The best material the frame can be constructed of is either stone or slate. Of stone, marble is the handsomest and easiest procured. Slate is however preferable to marble on account of its superior durability, and it is susceptible of the highest polish and finish; it is usually marbleized for the purpose (as when used for mantles) combining the beauty of marble, with the durability of slate. The slate is particularly preferable, because a tank manufactured of it can either be used for fresh or salt water. Not so however with marble; the chemical properties of sea water soon destroy the surface, defacing the beauty of the same. With iron tanks the salt water creates an oxide rendering them unadapted to its use.

For a fluvial tank, although slate and marble make the handsomest material to be used in their construction, iron frames answer well enough if properly manufactured. Wood is objectionable for two reasons, first, want of durability; second, liability to leakage; for few, indeed very few, of the wooden tanks I have seen in use, but were subject to the latter failure, one of the chief causes of the same being its 
porous character, wood being so susceptible and so easily effected by the variations of the temperature.

As a general thing the tanks manufactured for sale in this country are composed of iron, only a comparatively few being of marble or slate. Those manufactured of iron are usually ornamented by japanning.

In regard to the general proportions of a tank, as a rule the breadth and heigth should be relatively half the length, these proportions should necessarily be graduated according to the size of the tank. It is usually the fault that tanks for Aquarium purposes are manufactured with too great a depth. It is essential in a good Aquarium tank that the glass should be as clear as possible: for this purpose English, French or German plate is requisite; greenish glass so commonly used deteriorates the beauty of the same. Another advantage plate glass possesses is its strength.

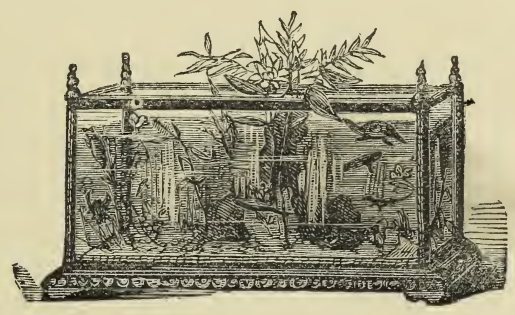

TIIE RECTANGULAR TANK.

The rectangular shape undoubtedly is the best form to display the beauties of the Aquarium. The octagon or sextagon forms cannot be fitted up to the same advantage, because the lights of glass are necessarily of small proportions, the divisions of the tank obscure the view, marring the 
picturesque effect. Rectangular tanks having partially solid ends, a small oval glass being inserted in the same, are preferable alike with those having solid ends, to the open or glass end tanks, for reasons that will be assigned in the remarks upon the effects of light. Mr. Lloyd of London, the most extensive manufacturer of tanks in the world, has patented a tank divided longitudinally into two distinct sections in the interior; the back section designed as a receptacle for new water and disconnected with the front except when its use is required; although great numbers of these tanks are manufactured and sold, yet in the opinion of eminent English Aquarists no real advantange is obtained by this peculiar arrangement. 'To attempt to enumerate all the styles that have been manufactured and offered to the public for sale, would exceed altogether our limits. I will however notice a new style lately introduced called the vase style, although displaying taste in their manufacture, are very illy adapted for the purpose they are constructed. They are in the form of a vase nearly three times as long as wide, altogether too deep, the ends bulged or expanded into a semi-circle, the top like an oval or elliptical jar, leaving not over two-thirds of the water surface exposed to the air; this is a fatal error in any tank, as it is positively requisite that all the surface of the water should be unobstructed. It is on this account that open glass jars are preferable to globes, for not only does the water receive more fully the benefit of the air, when its surface is wholly and equally exposed, but another advantage gained in the properly constructed tank is, that the temperature of the water is not elevated above its natural degree, as is the case when the top is partially closed, as in the vase style above referred to. 


\section{CHAPTER IV.}

THE LOCATION OW TIIE AQUARIUM IN REFERENCE TO

LIGHT AND IIEAT.

The best location for an Aquarium-Effects of light and heat-The only perfect plan-Effects of light upon fish.

ONE of the most important things to be considered in the proper arrangement of the Aquarium, is its situation in respect to light and heat. In the first place it should be placed in as cool a location as possible, as far removed from artificial heat as convenience will admit. And even more important is the subject of light, this being the grand mainspring of life to both the animal and vegetable world; without its natural influence, animal life would become blind and vegetation cease to germinate. In view of its importance we should endeavor to have the light act as naturally as circumstances will admit of upon our miniature aqua world. It behooves us then to consider how we should place the tank with regard to light, so as to approach nature and her laws as closely as possible. With this object in view as our guide, we easily discern that in their native waters animal and vegetable life receive their light from above, therefore we can immediately conclude that such is the only natural position they should be placed in, in regard to light. In view of this, the only perfect plan is to have the tank so constructed and placed, that the light can only enter it from the top, or 
surface of the water: this is correct because it is natural. In our attempts to domesticate, rear and keep in confinement animal and vegetable life, our primary object should be to surround those objects with as natural circumstances as we can.

In the fine collections of the Royal Zoological Society of London, the Derby Institute of Liverpool, the Hamburgh Aquarial Gardens, and others in Europe, this principle is adopted; all the light entering the halls passing directly through the tanks from the top, acting naturally upon the life contained therein and producing to the spectator a beautifully illuminated effect, the exquisite beauty of which must be seen to be properly appreciated. In the Aquaria of the American Museum in New York, which at the present time is the only public exhibition of the kind in the United States, this excellent principle has not been adopted, (the building not being suited for the purpose); there the tanks have glasses front and back, the light passes through from different directions, and this unnatural degree of light causes diseases to the fish, in many cases rendering them blind. Especially is this the case with the Diodon maculata-striata or Spot Striped Balloon Fish, whose eyes are brilliant emerald, and altogether one of the most curious of our native marine fish, and well adapted to the Marine Aquarium under favorable circumstan-

- ces. This unnatural degree of light also causes great changes in the colors of various species, the most remarkable of which I have observed, is in the new species of Pomotis I discovered in the tributaries of the Hackensack River, New Jersey, and which I named the Pomotis on account of its natural fondness for shady and secluded locations. In this new and interesting species, the colors almost entirely fade when exposed to the strong light to which most Aquariums are 
placed in. This fact is universal with this fish, as I have placed many hundreds of them in such Aquariums and the result always was the same. Of this fact I shall speak more minutely in the description of the fish and its habits. This powerful light acts directly the reverse in the case of its congenor, the well known common Sun Fish, Pomotis Vulgaris; in this it tends to intensify the color, rendering it much darker and richer. This may be accounted for from the fact that the common Sun Fish delights to bask in the strong sun light, from which circumstance it received its name.

In this new and improved location for placing the tank, but one glass is used in the same, the front one, the ends and back being solid, the window being above the tank, enclosed with darkened screens that surround it and descend to the top of the tank, concentrating every ray of light into the surface of the water, and all the light entering the apartment passes through the tank.

It cannot however be expected that many individuals can or would be able to adopt this plan of light, yet all can use discretion in placing their Aquariums in as good a position in respect to light and heat as circumstances will admit. Never place it directly in firont of a window so that the light passes through it, as many do, for in viewing an Aquarium to advantage, we should look with the light, not against it; besides those minute and troublesome plants, the Tyndarideas and other Conferva, grow so rapidly they soon discolor the water, coating the interior with a green slime, that frequent changes of water will not eradicate.

Neither should your Aquarium be placed where comparatively no light strikes it; this is the other extreme, in that case your vegetation will soon wither, loose its brilliancy of coloring, droop and die. 
Van Mons and Vasali, two distinguished European philosophers, assert that the light of a lamp and even of the moon exercises a coloring influence upon plants. I know from experience that aquatic plants, if kept in a dark room for a few days, no matter what quantity of water they are kept in, immediately begin to decay, and after it has actually commenced, no amount of light is adequate to their restoration. This is particularly the case with the Ceratoplyllum demersum. 


\title{
CHAPTER V.
}

\author{
ARRANGEMENT OF THE AQUARIUM.
}

Arrangement of the Aquarium - Rockwork, how arranged - Instructions as to its proper arrangement-Effect produced upon fish by long confinement without food-Food a necessity for their preservation and health-Diseases incidental to fish.

IN the interior arrangement of the tank and its conversion into an Aquarium, taste and skill are requisite to guide us in our labors. Many minutia to be employed, which however well the experienced Aquarist may be skilled in, yet in words he cannot convey to others. But the following is a brief sketch of the general modus operandi requisite.

The position being selected under guidance of our previous chapter, see that your tank be thoroughly cleansed; then cover the bottom of the same to a depth of one to three inches (according to the size of your tank) with well washed pebbles or river sand, care should be taken not to use salt water sand. A few natural rocks, readily procured in the environs of the city, are requisite for picturesque effect; these should be grouped so as to have a careless or accidental appearance, avoiding too much formality, as in this way they present a much more natural appearance. Rocks so placed that they represent one or more arches or bridges, under which the fishes can pass, have the most pleasing effect. The 
extent of rockwork should be governed by the dimensions of the tank. But in all attempts of this kind towards ornamentation, avoid artificial representations of rocks manufactured of clay; let us follow nature as near as we can and not burlesque it. An excellent substitute for rockwork is pumice stone, this can be procured in large pieces and is readily cut into any desired form; it possesses in fact one great advantage over natural rocks, its lightness never endangering the breakage of your glass by accidental displacement. Persons not fancying this arrangement of the rocks, can adopt another very good plan, by leaving the centre of the tank uninterrupted by them and forming a ledge of rocks at the extreme end of the same; it can be arranged very tastefully this way. After you have planned the position for your rockwork, care should be taken that they set firmly together, as their falling would endanger the breakage of the glass. Your rocks being grouped to advantage and firmly placed, the next step is the introduction of the plants; if your tank is large, you will require several distinct species, these should be selected with a view to variety of color and form of foliage. Before placing them in, see that they are carefully cleansed of all extraneous matter, and be sure they are firesh and but recently taken from the water; fasten them down securely in the niches of the rockwork, and a few amongst the pebbles or sand. They should be secured without string as it soon rots and the plants become loosened from their place; a small stone carefully laid upon their roots, or the same enclosed within a ball of clay are more permanent. When they are grouped to advantage, (in doing this much taste can be displayed), fill the tank with water. In filling it, care should be taken not to dash the water so as to dislodge any of your 
former work; a syphon made of small rubber hose answers the purpose very well, by elevating the bucket containing the water above the level of the tank, placing one end of the hose in the same and by exhausting the air out of the pipe, the water will pass from the bucket to the tank freely. This syphon is formed easily by placing the end of the pipe to your mouth and drawing your breath strongly; the water under this suction power forces the air out and then flows freely. This syphon can be produced another way, that is, by filling the pipe with water, closing up the aperture at either end with your fingers, then place one end in the bucket below the surface of the water, and as soon as your finger is withdrawn from the other end, provided it is held below the level of the end in the bucket, the water will immediately flow. If not supplied with a hose of this description, a watering pot answers the purpose very well. The stream should be directed so as to strike the sides of the tank, in this way it can be filled with less disarrangement than by any other. The tank should not be filled too full, that Tritons or Turtles can crawl out, or Trout, Pickerel or Dace jump out, as they are liable to do if such is the case. A small Island made of cork and covered with moss, upon which may be grown one or more small ferns or other marshy plants, adds greatly to the beauty of your Aquarium, and affords a convenient and necessary resting place for Tritons, Salamanders, Turtles or Cray Fish, to rest upon, as they of necessity require some place of the kind above the surface of the water. If you. do not choose to furnish this floating resting place, a substitute can be adopted, by allowing the rocks to project above the water surface.

Of all things avoid over crowding; this is almost a universal error, people generally are never satisfied to have a 
few healthy fish in their Aquariums, but they place in it so many that the carbon thrown off by the same cannot be neutralized by a sufficient amount of vegetation. Avoid also too much rockwork, remembering this, the more rock you have the less water.

Should you desire to raise any of the various species of frogs from their incipient stages, or rear any of the aquatic Coleoptera in your Aquarium, it is necessary to cover the same, to prevent their escape; this is easily done by constructing a light frame work fitting the top of the tank and covering it with gauze or fine netting.

Of all the Animal Kingdom, whether warm or cold blooded, none can sustain life so long without food as fish; yet to keep them healthy and prosperous they should be fed. The Carp will live for months in the tank without introduced food, yet they become deformed; the stomach is drawn up so that the under part of the fish is concave, and in the same proportion as this is contracted the back or dorsal line is raised, forming a highly convexed line, giving to the fish a deformed appearance. But whilst such is the effect produced upon this fish by long confinement without introduced food, it must not be understood thereby, that all the deformed carp we so often see for sale in Aquaria stores, receive their deformity thereby; by no means! In its appropriate place allusion will be made specially to this deformity.

Fish should be regularly fed or they will prey upon one another; it is on this account, that so many object keeping the Pomotis vulgaris and appendix (Sun Fish) in their tanks ; they complain and justly too, that they kill the other fish; of course they will if not regularly fed. Naturally carnivorous, they require considerable introduced food, and if not supplied 
help themselves to their smaller companions. Who that knew anything of the natural habits of Trout, Pickerel or Perch would expect them to live on water alone? All the Perch family are carnivorous requiring considerable introduced food. So with the Pimelodus or Cat Fish, they also are very voracious. The Cyprinus (Carp), the Catastoma (Suckers), the Labeo (Chub-sucker), and other genera are vegetable feeders, scarcely requiring introduced food.

Fish, like all animal life, are subject to diseases, but unlike the higher orders of animals, but little can be done for them. Those beautiful Angel Fish, Holicanthus ciliaris, which so many have so much admired in the Aquaria of the American Museum, are very much subject to attacks of vertigo, which usually proves fatal. Sometimes when so attacked, by lifting them gently out the water for a few seconds, it will pass off and the fish resume its former appearance; but I have found these attacks on the brain return from time to time, and eventually prove fatal. During these attacks the fish is unable to maintain its equilibrium, dashes wildly about striking the sides of the tank, swimming often perfectly inverted, reeling over and darting about whilst the paroxysms last.

The most general disease fish are subject to undoubtedly is constipation, occasioned likely from the want of their natural food.

Some species are subject to peculiar warty excrescences growing upon them; I have observed this most particularly the case in the Pomotis.

Fish intended for the Aquarium should be handled with great care, the less the better, as they are easily injured, much easier than is usually imagined. If a fish be allowed to fall to the ground, no perceptible injury may be apparent at the $\mathrm{C}^{*}$ 
time, but in the space of four or five days, the wounds make their appearance in the form of bruises that soon assume a wooly appearance; these when examined under a powerful lens, are found to be vegetation; a parasitical fungi that spreads over the fish, and in a majority of cases, proves fatal. When fish are so injured, the wounded parts should be carefully cleansed with a soft sponge attached to a stick from day to day; their lives may often be saved by this process.

Some of the larger species are subject to living parasites that attach themselves to the gills, and ultimately destroy them. When the Carp or Gold Fish sicken, their bright colors fade, and assume a dull yellow color.

If any fish in the Aquarium show signs of disease, they should be immediately taken out and placed by themselves, to preserve the health of the remainder.

The eye is the best index of health; as long as that is bright and clear, all is well; but when a film appears upon it, it is a sure indication of the presence of disease. 


\section{CHAPTER VI.}

THE ANIMAL LIFE OF THE AQUARIUM.

\section{'THE FISH.}

Specific descriptions of the various species applicable to the Aquarium.

Precedence must be given to the Golden Carp or Gold Fish on account of its popularity.

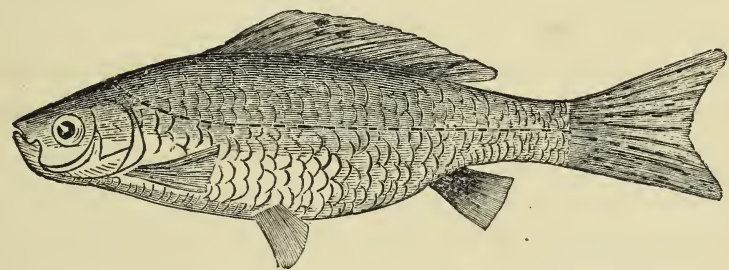

Cyprinus auratus.-Golden CARP or Gold Fish.

The Gold Fish is undoubtedly a degenerate or cross-bred variety of carp, having no established specific character ; in this respect being the only example of the kind known to Ichthyology.

It was originally a native of China and was introduced into Europe nearly two centuries ago, to gratify the fanciful whim of Madame Pompadour of France, who at that period was the reigning favorite of the fashion and splendor at the French Court. It soon became a general favorite and was shortly 
afterwards introduced into Great Britain and other countries of Europe. We have no exact data as to the time of its introduction into this country, but it is of comparatively recent date; it is only since the discovery of the fact that fish, reptiles, insects and plants could exist and thrive together in an artificial vessel, that the fact of the existence of Gold Fish in our midst became generally known to the public. In China many distinct varieties of the Carp are known; De Savigney in his Natural History of China figures eighty-nine distinct varieties. Much trouble and expense has been used to produce varieties by the amalgamation of species in China ; in this manner an endless variety of form and color was produced. It is a well established fact in Natural History that two distinct species of animals, whether fish, birds or quadrupeds, if crossed, their progeny are hybreds, and henceforth necessarily loose the specific characters of the species from whence they derived their origin. The Golden Carp as introduced into Europe undoubtedly had lost all specific character, from their long domestication; hence the infinite variety of forms and colors they assume, firom the most symmetrical to deformed hunchbacks. A few have a triple caudal, in some the dorsal fin is entirely wanting, in others only a rudimentary one, in some a prolongation of the first two or three anterior rays of the same, whilst the posterior part is wanting. The colors vary equally with the anatomical structure; some are pearly white, whilst others are deep black with perhaps a few blotches of red or white or both, others brilliant red, some with shades of greenish yellow and metallic brown; in short it would be impossible to enumerate the variations of color assumed by the Golden Carp. What is commonly known as the Silver Fish is only a variety of the Carp, in some of these the silvery 
white always remains, whilst others turn red, red and white, red and black, or the three combined, and in many of the Silver Carp the back is of a beautiful purple. The change of color is not always from the Silver to the Gold Fish, but often vice versa; I have frequently had bright Gold Fish lose their red coloring and assume the plain garb of the Silver Fish. The brightness of color in the Golden Carp appears to be local; in some ponds inhabited by these fish all are high colored, these ponds I have observed usually had a rich alluvial bottom, whilst in ponds having clayey or yellow mud bottoms the fish are usually of a poor color, having a yellowish tinge.

The Gold Fish are and no doubt always will be the most popular habitants of the Aquarium, capable of enduring the greatest variations of temperature, whilst their gaudy and varied coloring render them the most attractive to the superficial observer.

If an Aquarium be in a good condition, healthy, the plants contained therein in a good growing state, in such an Aquarium the Gold Fish require but little introduced food, as the water in such a tank contains large quantities of animalculæ and minute vegtable spores, that keep the fish in a much healthier state than any food usually given them. Many foolish notions are entertained relative to the sexes of the Gold Fishes, one of these most prevalent is, that those varieties only that have a short or abbreviated dorsal are males ; this is quite erroneous. Some, too, think that the abbreviated dorsal is indicative of a distinct species, and have asserted that this peculiarity exists only when the dorsal line of the fish is highly convex, causing the fish to appear deformed; this also I am satisfied is incorrect, as I have specially selected at times large numbers of 
Carp for their symmetrical form, and many of them possessed the contracted dorsal fin.

The number of fin rays likewise are irregular, one principle feature that determines the identity of species; they usually occur in the Carp, as follows, (but vary occasionally in individual specimens,) Dosal, sixteen to twenty rays; Caudal, seventeen to twenty; Anal, six to eight; Ventrals, nine, and Pectorals, fifteen. The Gold Fish grows to a large size, the largest about twelve inches in length and weighing nearly two pounds; they do not bite very freely at bait, and are little esteemed as an article of food, being coarse and dry.

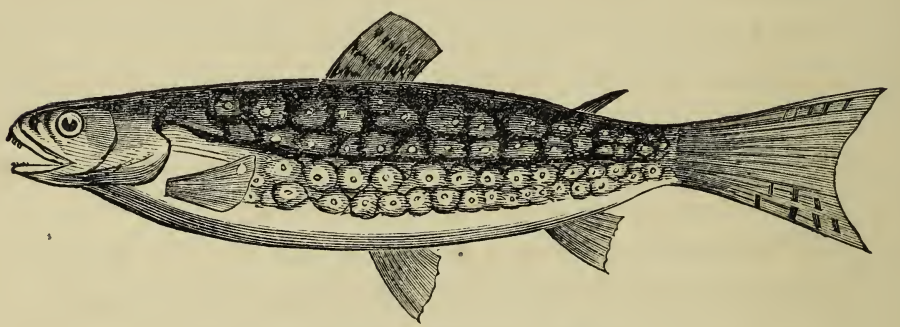

Salmo fontanalis. - Brook Trout.

The Salmo fontanalis - Speckled or Brook Trout. Undoubtedly the most beautiful of our fluvial fishes. They inhabit swift and clear running streams and are the delight of the angler. If introduced into the Aquarium, they must be supplied with running water, and should be well fed, as they are naturally very voracious; they will eat beef with avidity, and thrive well under favorable circumstances. In all cases Trout are best kept by themselves, and the tank should be securely covered with net work to prevent their jumping out. The Trout is a smooth scaled fish, the scale being minute, oblong and imbedded in the skin. 
Specific Ciraracter : Upper part of the head and back dark bronzed green, mottled with darker shades. General color of the body, clear horn color, irregularly mottled with darker hues. Sides of the body varied with tinges of blue and silvery white. Lateral line quite distinct and slightly curved downwards. Sides of the body with numerous small bright vermillion colored dots, having the appearance of red sealing wax. Dorsal, thirteen rays of a light yellowish color with interrupted olive brown bars, three in number. Caudal, nineteen rays, banded with numerous obscure bands. Anal, fourteen rays, tinged with rich reddish hues as in the caudal, the first or anterior ray clear white, the second and third tipped with white only, tip of the fourth black, broadly margined with white. Ventrals, eight rays tinged with red, the fins varied with white and black as in the anal. Pectorals, twelve rays, pointed, first light yellow, second blackish brown, the other ten, orange. Irides, white.

The brook trout attains to a large size, from three to four pounds being the limit. Two and two and a half is considered very large.

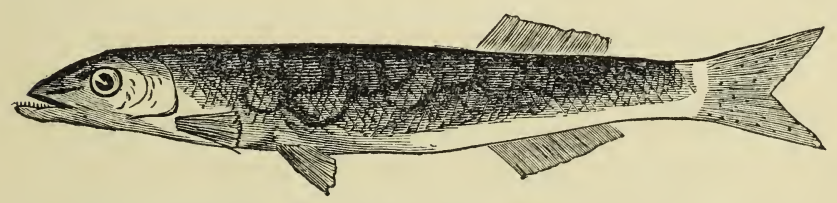

Esox reticulatus.-Comnon Pickerer.-(Le Seur.)

The Pickerel, like the Trout, affords excellent sport to the angler, this species sometimes exceeding three feet in length. When quite young they are suited to the Aquarium, but if large must be kept by themselves; in all cases they must be regularly fed, and will eat nothing but live food. 
Specific Chraracter : General color, deep olive green above, tinged with yellow on the sides, the irregular bands dark brown. Dorsal, eighteen rays, tinged with green. Caudal, nineteen rays, shaded with greenish. Anal, fourteen rays, tinged with light red. Ventrals, ten rays, also tinged with red. Pectorals, sixteen rays. Irides, yellow varied with blue. Caudal, deeply emarginate, nearly forked.

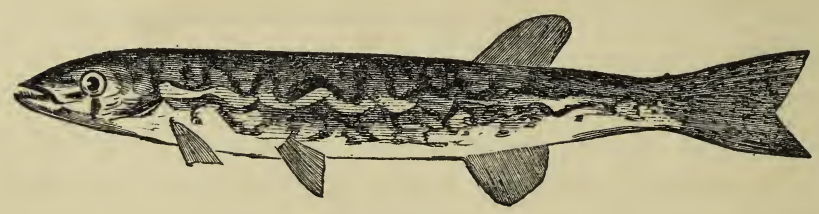

The Varied Picherei.-Esox fasciatus.-(De Kay.)

The Varied Pickerel is a much smaller fish than the one last described, seldom exceeding ten inches in length. They are quite tenacious of life and do well for the aquarium, they require the same food as the reticulatus.

Specific Character : Whole upper parts dark olive brown, a distinct dorsal line of light brown extends from the termination of the upper jaw to the base of the caudel. Sides beautifully. mottled, becoming indistinet towards the belly. A well defined blackish brown line from the eye to the angle of the jaw. Pupil of the eye black, irides whitish, tinged with green. Dorsal fin, fourteen rays. Pectorals, thirteen. Ventrals, nine. Anal, thirteen, and Caudal, twenty, and is only slightly emarginate. Ventrals and anal tinged with red strongly, the pectorals, dorsal and caudal slightly. This species of Pickerel are easily tamed, so that they will allow you to stroke them as they lie on the surface of the water, and are 
the only fresh water fish adapted to the Aquarium in which this peculiarity exists. The same thing can be done to the Pilot Fish, one of our marine fish, the one that usually pilots the sharks whilst in search of prey.

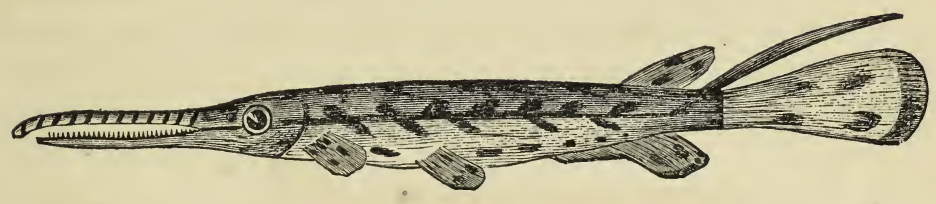

The Lepisosteus. - Bison-Buffalo Bony Pike.

The Buffalo Bony Pike or Alligator Gar, is the most peculiar of any of our fluvial fishes. They are plentiful in the western portion of the State of New York, and attain a large size, specimens having been taken from three to four feet in length. When small they are a great acquisition to the Aquarium. The one from which the above cut was taken had been in the Aquaria of the American Museum over six months, and thrives well growing rapidly, eating two or three small Fundulus zebra about three times a week.

Specific Character : General color, bright light cinnamon, upper part of the body with a row of black spots along the dorsal line. A very conspicuous lateral band extends from the tail directly through the eyes to the extremity of the jaws, this lateral band is jagged or irregular along its upper and lower margins; along the sides are several deep black blotches immediately above the lateral band, lower part of the sides more or less marked with black. Under part of the body white, with numerous black markings. Pupil of the eyes black, irides cream color. Dorsal, eight rays with sev- 
eral conspicuous black spots. Caudal, fourteen rays, the webs slightly scolloped at their tips, with five or six very large black spots mostly arranged near the extremity and three or four near the centre. Anal, ten rays spotted with black. Ventrals, seven rays conspicuously marked with black spots. Pectorals, fourteen rays also marked with black spots. Mouth armed with a fine row of small acute teeth on its inner margin. Caudal appendage very flexible, capable of being raised or depressed at pleasure, and used as a rudder. This

- caudal appendage is peculiar to this species.

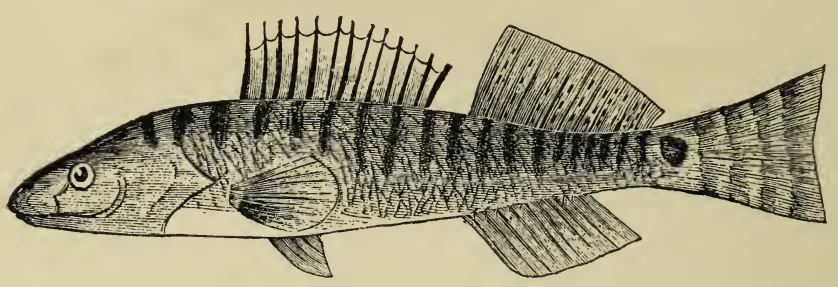

Pimeoma sub-fasciatum.-Ciramplain Pickering.

The Champlain Pickering or as it is commonly called the Little Pickering. The above figure represents the full average size of this little fish. They are very plentiful in some portions of the waters of Lake Champlain, where they may be seen in the clear waters of the lake darting about with great swiftness.

Specific Character: General color light olive green, back banded with twenty vertical bands that descend about half way down the sides. The gill covers, very beautiful metallic green with rich golden reflections. A well defined and conspicuous round spot of a dark olive color at the base 
of the caudal, this spot being about the same shade of color as the vertical bands. Pupils, purplish; irides, silvery. Anterior dorsal, thirteen pointed rays, the rays clouded at their base; posterior dorsal, fifteen rays, the webs slightly dotted with brown. Caudal nearly even, fifteen rays and having four or five distinct vertical bands of a dark brown color. Anal, twelve rays, Ventrals, six rays, Pectorals, rounded with fifteen rays.

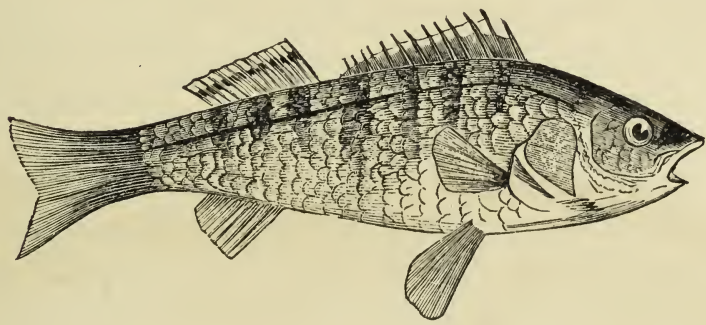

Perca flavescens.-Averican Yellow Percir.

This beautiful fish possesses numerous cognomens. American Yellow Perch, Black Banded Perch and Banded Bass, by which it is known in different sections of the country; the first, however, is the proper one. This beautiful fish is noted for the richness of its coloring and its excellent edible qualities, being highly esteemed by epicures. They attain a large size. I have taken them two pounds in weight, and have seen them much larger. When young they are an acquisition to the Aquarium, and thrive well in a large tank; they inhabit most of the large lakes of the northern States and in some locations are very numerous. This species is 
closely allied to the Perca fuviatilis, or Fresh Water Perch of Europe. In Rockland Lake, Rockland County, New York, they are very plentiful; also in Lake Ronkonkoma they are numerous and attain a very large size, being also the only species of fish found in this lake; this latter fact I give on the authority of an intelligent gentleman, a resident in that locality. They are rarely if ever taken in running streams. Like all the family of Perciadce, they are carniverous, and require considerable food, and will devour beef with avidity.

Specific Cinaracter: General color of the upper parts dark and rich olive green; sides tinged with greenish yellow; lower parts of the body rich yellow, extending up the sides where it is blended into the olive green of the upper parts; chin and throat flesh color; upper part of the body and sides with six to eight blackish vertical bands of irregular lengths, extending partly down the sides, gradually becoming lighter as they reach the lower half of the body; pupils of the eyes black, irides, rich yellow; anterior dorsal, dusky, with fifteen acute pointed rays; posterior dorsal, fifteen or sixteen rays, nearly even, with a row of spots on the spines of the same; caudal rounded, slightly emarginate, consisting of seventeen rays ; anal, bright orange, have two spinous and eight articulated rays; ventrals, bright orange with six rays ; pectorals, fourteen rays. A lateral line extends from the upper part of the gill covers, ascending in a curve upwards and parallel with the convexed back of the fish. 


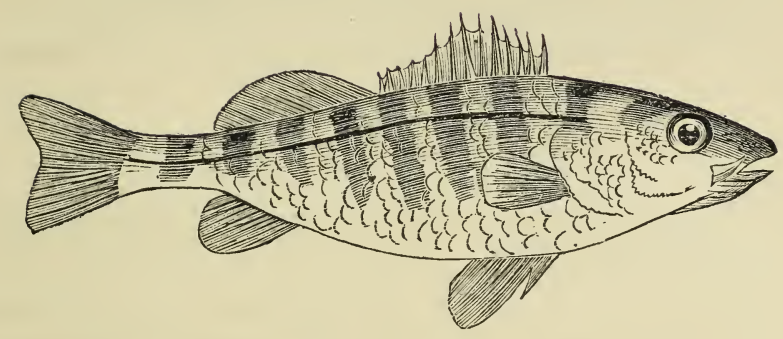

Perca serrata-gramulata.-Rovgh YeiLow Perch.

This species bears a considerable resemblance to the last mentioned species, the chief differences being the following. In this, the anterior dorsal is unspotted or clouded as in the favescens, whilst this one possesses a series of roughened radiated lines on the head, this latter peculiarity suggested its name. In their habits they are allied to the flavescens, but are not so numerous or generally distributed.

Specific Character : General color and markings the same as the American Yellow Perch. Anterior dorsal, fourteen rays, posterior, fifteen rays. Caudal, seventeen rays. Anal, two spinous and seven articulated rays. Ventrals, one spinous and five articulated rays. Pectorals, thirteen or fourteen rays.

$$
\mathrm{D}^{*}
$$




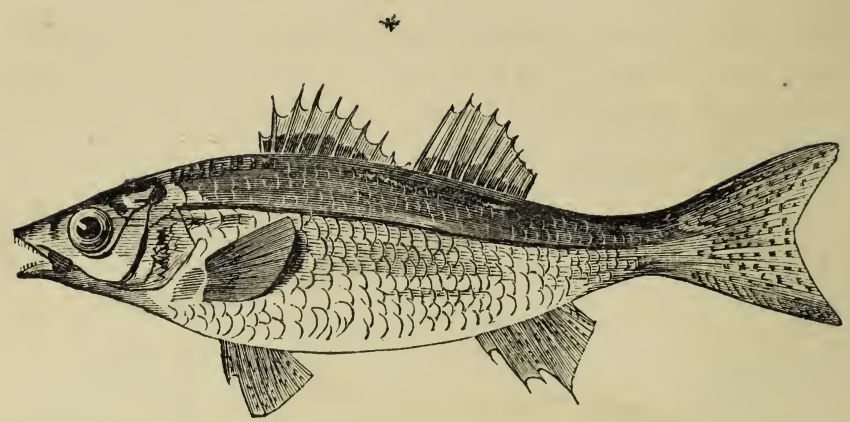

Labrax pallidus.-Wuite Perch. (Mitchell.)

This fish is also known under the name of White Bass. Their habits are closely allied to the Perca and bear an affinital resemblance to them. They attain to a length of ten to twelve inches, although Dr. DeKay says it never exceeds four to five inches. This species is plentiful in the Passaic and its tributaries, the Hudson, the Croton and many other streams of New York and New Jersey.

Specific Cifaracter: Body compressed, dorsal line considerably elevated, sharply descending towards the end of the jaws. General color pale bluish white above, sides and whole under parts white. Dorsal fin apparently divided into two sections as in Perca, but upon close examination it is found to be connected by a minute membrane. Anterior portion of the dorsal, nine acute spinous rays; posterior portion of the same, thirteen rays. Caudal, emarginate with seventeen rays. Anal, ten rays, the first anterior one short and spinous, second and third spinous, and the remainder articulated, the webs of the same slightly dotted with brown and tinged with pink. 
Ventrals, pinkish, having one anterior spinous and five articulated rays dotted as in the anal. Pectorals, seventeen rays clouded at their base. Lateral line distinct, curved down- wards.

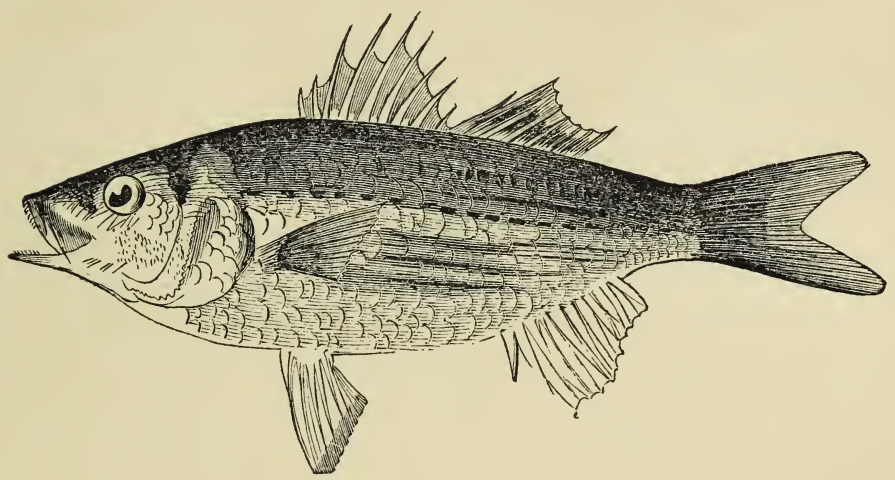

Labrax nigricans.-Smat.l Black Bass. (DeKay.)

This species is known under various local names; Small Black Bass, Black Perch, Fresh Water Black Fish, etc. They inhabit deep ponds in Queens and Suffolk Counties, Long Island, lie close at the bottom, are extremely shy, in their habits resembling the Common Black Fish. They afford excellent sport for the angler, readily take the fly, and attain a size of a foot in length. When small they are a great acquisition to the Aquarium, are easily kept, being very tenacious of life.

Specific Criaracter: Body compressed as in the pallidus, and having the dorsal line elevated and descending in a simi- 
lar manner. General color, head and whole upper parts deep veivety black, lighter as it descends; sides tinged with yellow indistinctly. Pupil of the eye black; irides, yellow. Dorsal, consisting of two parts; anterior portion more elevated than the second, consisting of nine or ten rays; posterior fin, one spinous and twelve other rays. Anterior dorsal has the edge of the spinous membrane black. Posterior dorsal with the upper half of the membrane beautifully diaphanous, lower half of the same clouded, and divided from the upper by a well defined longitudinal line. Caudal, furcate, tips sub-acutely rounded, clouded at the base. Anal, with three spinous and eight branched rays. Ventrals, one spinous and five branched rays. Pectorals, sixteen rays. Base of all the fins light greenish yellow. Lateral line distinct but interrupted, descending downwards.

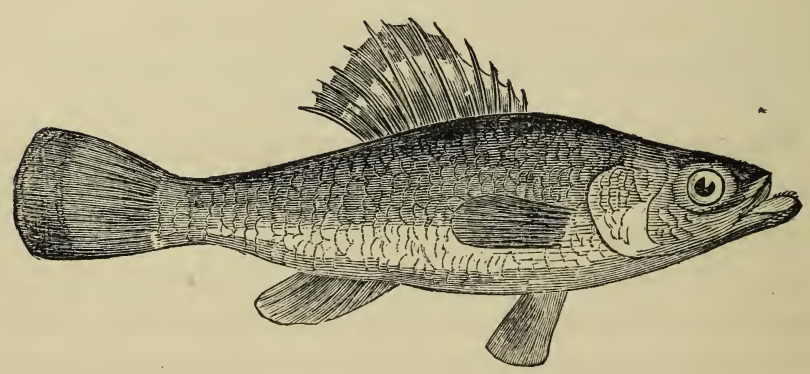

Aphredoderus sayanus.-Spineless Perch.

This small fish is rare, and as yet but little known, the above figure represents the average size. 
Specific Characteri; General color above, dusky brown, whole under parts, light yellowish. Dorsal, with three spinous and eleven branched rays, membranes, clouded at their tips. Caudal, rounded with seventeen branched rays. Anal, with three abbreviated spinous and seven branched rays. Pectorals, with twelve rays.

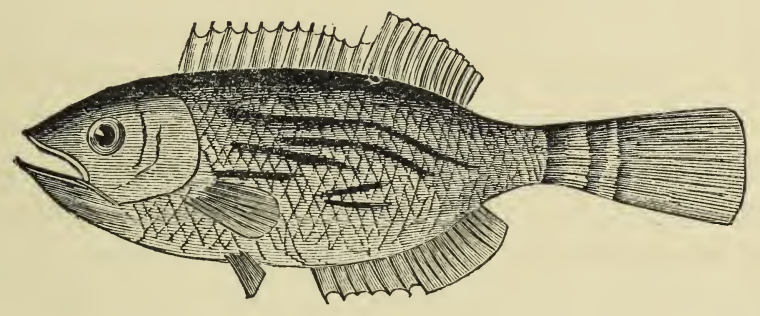

Centrarchus ceneus. - Fresi $W_{\text {Ater }}$ Bass.

This fish is common in the waters of the upper part of the State of New York, viz: the Erie canal, Hudson and its tributaries, Lake Champlain, etc.

Specific Character: General color, dark greenish bronze, a dark lateral curved line along the sides, below this a series of irregular waved lines of various lengths, the upper one longest. Dorsal, with eleven spinous and twelve articulated rays. Caudal, seventeen rays. Anal, six spinous and eleven articulated rays. Ventrals, one spinous and five articulated rays. Scales, diamond shape. Eyes prominent and large. Length six to ten inches. 


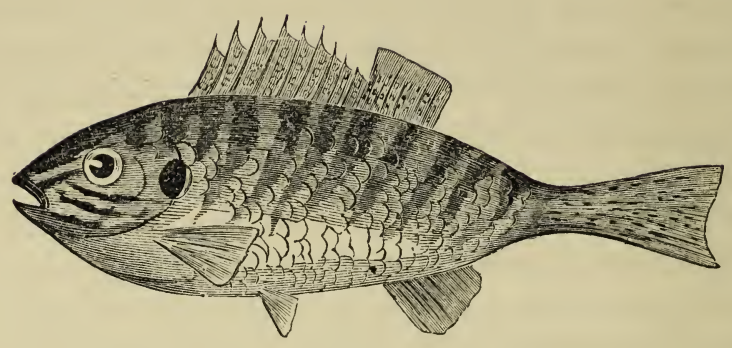

Pomotis Vulgaris.-Common Sun Fish.

This common but beautiful fish is known under a variety of local names, such as Sun Fish, Pond Fish, Pumpkin Seed, etc. No better denizen of the tank can be selected; lively, vivacious, hardy and handsome, he comes well recommended to us. Many are prejudiced against them, because they are apt to attack other fish and sometimes kill them. This however I am satisfied they never do when properly fed; but if left to starve, being naturally spirited and pugnacious, they will attack and destroy their more feeble companions. I have placed at various times numbers of adult Sun Fish in the Aquaria, where they have been kept for many months in the same tank with Gold and other fish, and have never molested their companions, because they were regularly and liberally fed.

In Rockland and other large Lakes, where the water is so clear and pure that the bottom can be distinctly seen at a depth of ten to twelve feet, I have observed the habits of these fish during the season of reproduction, with much pleasure. They select those localities where the bottom is 
of a sandy or light character, and scoop out a large hole, circular in form, and from three to four feet in diameter; here their spawn is deposited, and woe to any fish large or small that dares invade its sacred precint: the largest fish they instantly drive away, darting at them with great ferocity, a proof that even fish have an innate affection for their offspring. These circular spawning beds were distributed at intervals over a considerable portion of the lake.

They have a wide distribution, being found throughout almost all portions of the United States. In conjunction with my friend Capt. J. H. Mortimer of Savannah, we have introduced them into private ponds of England, with what success time alone can determine.

Specific Character: Body greatly compressed; dorsal outline, high and arched; general color, whole upper parts and sides varied with metallic green and intermingled with black, darkest on the back cheeks and fore part of the head, with clear blue waved lines; opercles, lustrous blue and green; abdomen, bright sienna; pupil of the eyes, black; irides, greenish blue tinged with red; a large conspicuous black spot margined with bright red on the posterior angle of the opercle; dorsal and anal fins spotted with brown; whole body spotted with reddish brown spots; opercles, striated with reddish yellow bands converging to the eyes; dorsal, nine spinous rays, first, second and third, shortest, and ten branched, the middle spinous and branched rays longest; caudal emarginate, eighteen rays; anal, rounded, three spinous and nine branched rays; ventrals, one spinous and five branched rays; pectorals, yellow, ten branched rays; ventrals, immediately below the second spine of the dorsal.

In a specimen seven inches in length, now before me, the following are the relative measurements : Greatest depth of 
the body, three inches; centre of the eye to the end of the mouth, five-eighth of an inch; length of the dorsal, two and one-half inches; heighth of the same in its most elevated part, one and one-quarter inches; length of the caudal, one and one-quarter inches, breadth at its extremity, two and one-quarter inches, at its base one inch; thickness of the body, one and one-eighth inches; length of the anal fin, one and one-quarter inches; distance from the vent to the anal, one-quarter of an inch; from the anal to the ventral fins, one and three-eighths inches; length of the pectorals, one and five-eighths inches; from the centre of the eyes to the centre of the base of the pectorals, one and three-eighths inches; from the centre of the eyes to the prolongation of the opercle, one and one-quarter inches.

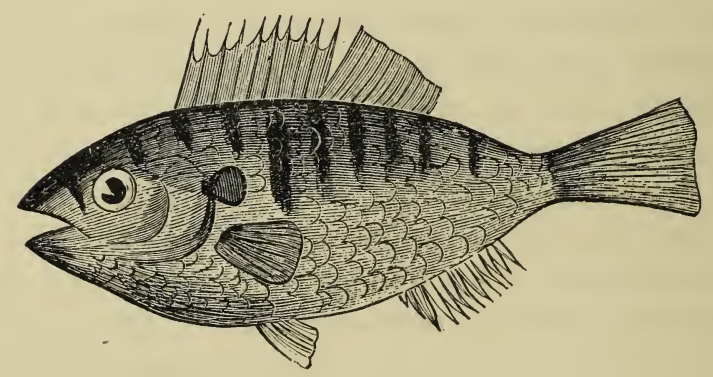

Pomotis appendix.-Black Eared Sun Fish.-(Mitchell.)

The Black Eared Sun or Pond Fish is a well defined species, although not so well known or so widely distributed as the vulgaris. Dr. De Kay in the Ichthyological part of the 
work upon the Natural History of the State of New York, quotes this species from Dr. Mitchell, but says he never himself met with it; this is indeed singular, because in many localities they are very numerous. I have experienced no difficulty in obtaining fifty to sixty specimens of this fish in a few hours on several occasions, baiting with the common earth worm. They fully equal the vulgaris in size, their habits are similar, but their bodies are deeper and broader. The prolongation of the posterior angle of the opercle is a peculiar characteristic of this fish, and suggested its name. In some of the lakes and large ponds in the interior of New Jersey and the adjacent county of Rockland in this State, I have taken many very fine specimens of the appendix.

Specific Character: Body not so decidedly compressed as in the vulgaris, mouth larger. General color, yellowish brown. Throat and whole under parts, rich reddish brown, fading towards the posterior extremities. Prolongation of the opercle, ear-shaped and entirely black. Dorsal, ten spinous and eleven articulated rays. Caudal, nineteen rays. Anal, three spinous and ten branched rays. Ventrals, five rays. Pectorals, thirteen rays.

In some specimens I have taken, the sides of the body were tinged with a light bluish slate color. The lower parts are much richer in color than the vulgaris. 


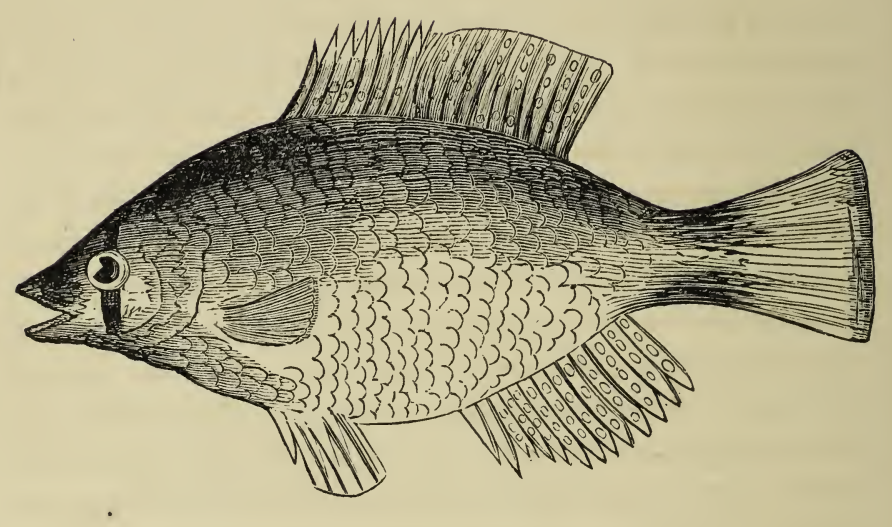

Pomotis secludens.

This new species of Pomotis I discovered a few years since in the tributaries of the Hackensack River in New Jersey, and here append a minute description of it. It will at once be observed that its characteristics are well defined, being in all cases uniform; and although extremely local, is very numerous in its special localities. Whilst the vulgaris and appendix love the sun light, delighting to bask in its warm rays, this species prefers secluded spots where vegetation to a great extent closes out the strong light. I find them exclusively in those localities where an excess of aquatic vegetation exists. When kept in Aquaria as ordinarily placed, in reference 
to light, they soon lose all their richness of color, the metallic hues on the flanks entirely disappears. The blue dots sprinkled over the sides fade out and they assume a plain garb of yellowish brown. When so faded out, the dark vertical bands are much more prominently seen than before upon their sides. This fact of their color being so quickly and decidedly changed when exposed to a strong light, may perhaps be accounted for from their natural habits of seclusion just mentioned. I have placed many hundreds of these fish in Aquaria, and wherever the same were too much exposed to the action of light, which I would remark is almost universally the case, the change of color always without an exception was the immediate result. In other respects they are hardy and bear confinement well; the chief organic distinction in this species is the remarkably full development of the fins, more especially the dorsal and anal. In the waters inhabited by them, grow masses of Ceratophyllum demersum and Lemna trisulca.

This species is small, never exceeding four inches in length, out of many hundreds taken, I have never seen any to exceed this length.

Specific Character: Body compressed as in all the species of the genus, fins greatly developed.

General color, upper part of the body deep blackish brown, with innumerable. small bluish dots. A pale lateral line proceeds from the upper posterior angle of the opercles, forming a curved line parallel with the dorsal ridge of the body, and terminating near the lower base of the caudal. The blue dots on the sides of the body arranged in irregular lines laterally. Flanks and abdomen, rich violet. Opercles with a conspicuous black oblong spot on its posterior margin, this 
black spot bordered with light blue on its upper, anterior and lower edges; the rest of the opercles, deep brownish black, spotted with bright blue. A broad and well defined black vertical band extends from the upper part of the head to the centre of the upper edge of the irides, continued firom the lower edge of the same to the base of the opercles. Scales broadly rounded, all of them margined with dark brown, with their centres lightest. Sides of the body with seven vertical bands extending the depth of the body.

Dorsal fin with eight spinous and ten branched rays, the first anterior spine very short, second and third progressively long and the five others nearly equal, the branched rays are each terminated by four distinct branchlets. Whole of the dorsal clouded with reddish brown, each ray distinctly dotted with a series of light blue spots. Caudal, largely developed, finely rounded, consisting of sixteen branched rays, four branchlets each, clouded and spotted as in the dorsal. Anal, rich reddish brown on its upper half, with two spinous and ten branched rays; the first spinous ray very short, the other double the length of the first. This fin is remarkably fully developed, and having the webs spotted with light blue, especially the posterior ones. Ventrals, sharply pointed anteriorly and well rounded posteriorly, consisting of one spinous and five branched rays, with four branchlets each; the shafts of the three first or anterior rays, reddish brown, the fourth and fifth, transparent; webs transparent. Pectorals, rounded, with eight branched rays of four branchlets each.

In specimens measuring three inches in length, which is a fair average size for this species, the following relative measurements are strictly correct: Body, highly arched, the first 
spine of the dorsal springing a little anterior of the highest point of the arch; ventrals placed in a line immediately below the second spine of the dorsal; vent, one-half the distance from the base of the anal anteriorly, as it is to the posterior base of the ventrals ; greatest depth of the fish, one and oneeighth inches; heighth of the dorsal, three-quarters of an inch; length of the caudal, three-quarters of an inch; width of the same, when fully expanded, one inch; dêpth of the anal, three-quarters of an inch; breadth of the same at the base, five-eighths of an inch, and when fully expanded, one and one-eighth inches from the tip of the first spinous ray to the tip of the posterior branched ray; distance from the end of the jaws, when closed, to the centre of the eye, onequarter of an inch; thickness of the body in its fullest part, three-eighths of an inch.

Two distinct punctures placed in line upon the head, equidistant betwixt the eyes; also four punctures, two on each side of the head, placed laterally with each other, and in a line with those betwixt the eyes. There are likewise two punctures besides the above, one immediately above the upper posterior edge of the irides, the other slightly below. Pupil of the eye, bluish black; irides distinctly tinged with red.

I have necessarily elaborated the specific characters of this new species, in order to clearly show the grounds upon which I base its distinction.

Amongst the interesting family of Leuciscadox-Dace, we have seven species, which I introduce to your notice as more or less suitable to our tanks, all of which are found in New York State. This family includes some of the smallest and most interesting fish our Fauna claims. When young, all E* 
can be used to ornament our miniature ponds. Throughout the United States, of course there are other species in addition to the seven herein described, as there are of other families; but it is deemed best to confine our work to those procurable in the vicinity of New York, but very few extra ones being introduced, and these only when possessing some remarkable or interesting feature to warrant their introduction.

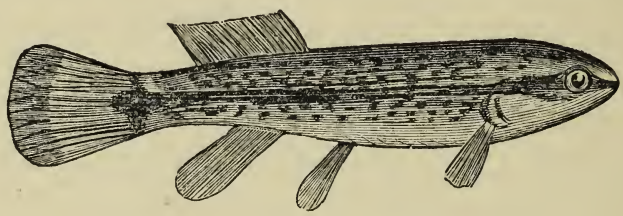

Leuciscus pygmceus.-PigmY Dace.

The first of the Leuciscus claiming our attention is the Leuciscus pygmaeus, Pigmy Dace or Rock Fish. Although one of the smallest of the Dace, its superior adaptability to the Aquarium entitles it to precedence. The tenacity with which it clings to life exceeds that of any known fish, not even excepting the Gold Fish. As a slight instance of the

- fact, I would state that on one occasion during the summer months, whilst returning to the city with a large number of these fish, I accidentally upset my can and lost all the water, and had to carry them a mile before I could replenish it, and although these little fish were carried a full mile without any water, not a single one died. They love to ascend sluggish streams to their source, and are usually found most plentiful 
where the water is shallowest. They lie still in their native streams, poising themselves almost motionless, and when they espy their prey, dart with great swiftness to seize it. They seem to be particularly fond of poising themselves in a vertical oblique line, either pointing upwards or downwards. In the tank they will freely eat the common house fly, IFusca domestica, and common earth-worm, and will likewise freely eat lean beef.

Dr. De Kay figures this species from specimens furnished him by Mr. John G. Bell, of New York; and must evidently have done so from dead specimens, as that gentleman describes them as having a lanceolate caudal or tail, whilst - they have most positively a fully developed and expanded fan tail, which is beautifully. rounded. If one of these fish be taken from the water and held in the hand whilst alive, his fan tail closes up and assumes a lanceolate; this will explain the error made by De Kay. Another proof of the value of practical experience. The same author also describes them as never exceeding an inch in length; I have, during the last four or five years, taken many hundreds four inches, and a few four and one-half inches in length. They appear to be extremely local in their habits, and are found in sluggish streams where aquatic plants abound.

Specific Cinaractir: Body, oblong, rounded, having the abdomen prominent; head, depressed, scaly, upper jaw shorter than the under; mouth, small; eyes, large and prominent; caudal, fan shaped, beautifully rounded; general color, varies greatly in individual specimens; in several now before me they are nearly black, whilst in others, also before me, they are light cinnamon color; if the shades of color vary, however, the markings are generally the same; sides of the 
body, marked with numerous lateral interrupted stripes of dark brown, also with a distinct lateral stripe of light brown; a black stripe extends from the eye to the anterior upper angle of the opercles; a black ocellated spot divided into two sections at the base of the caudal: this spot is surrounded with a very light brown marking, rendering the spot well defined; all the fins diaphanous; pupil of the eye, black; irides, light brown; dorsal fin, rounded higher posteriorly, twelve rays branched, first ray short, eighth ray longest; caudal, fan shaped, beautifully rounded, consisting of twelve rays branched in fours; anal fin, rounded, of eight rays middle ones longest; ventrals, five branched rays; pectorals, six rays branched and rounded; all the fins diaphanous; shafts, dark brown.

Although preferring live food, such as small aquatic insects, they will eat beef when cut in small bits.

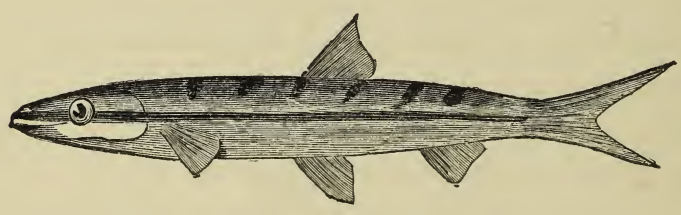

Leuciscus atronasus.-Black Nosed Dace.

This species is also called the Striped Dace and Black Striped Dace, they chiefly frequent clear running brooks and trout streams. No fish excels this in symmetry and few in beauty. I have observed a peculiarity in this fish which is 
strongly defined, that is the remarkable revivifying effect cold water has upon it. Most fish when they commence swimming in an inverted position, reeling over and floating upon the waters' surface upon their sides, in consequence of the high temperature of the water, cannot be revived even if the water be wholly or partially changed; indeed the reverse effect is usually the case, most species being injured and many immediately killed by too sudden a change of the temperature of the water; not so however with the atronasus. Cold water instantly revives this species and from experiments I have made in this direction, I have found it an almost infallible rule.

This species appears to be particularly fond of cold, clear running brooks having gravelly beds, found usually with Pomotis vulgaris, Catastoma pallidus, Hydrarqia diaphana and Astacus Bartonic. Many might say that the reason of this species being revived so easily with cold water is accounted for from the fact of its inhabiting, naturally, cold brooks, such however cannot be its solution, because its companions just mentioned are effected in just the reverse manner by a sudden change of water.

The Black Nosed Dace do not attain their full beauty during the first or second seasons, the red on the fins appearing in only adult specimens, they attain a length of three to four inches, rarely exceeding the same.

Specific Character: Body elongated and rounded, caudal, deeply forked. General color, whole upper parts, rich cinnamon brown, sometimes tinged with olive brown, back and upper part of the sides marked with a few irregular blotches of black, whole under parts, satin white. A very distinct and conspicuous lateral broad stripe from the extremity 
of the nose passes in a direct line through the lower half of the eyes, thence to the centre of the base of the caudal, this line is deep black, with another similar line running parallel with it of a light reddish brown color. A stripe of light cinnamon along the dorsal ridge. Eyes full and prominent, the pupils black, irides, light brown. Dorsal, dark brown, with eight rays. Caudal, dark brown, nineteen rays. Anal, higher than long. Ventrals, bright orange, eight rays. Pectorals, bright orange, fifteen rays. In the younger specimens the orange color of the fins are wanting, and the whole colors are less brilliant.

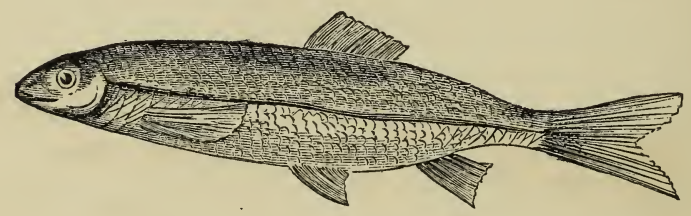

Leuciscus nitidus.-Shining Dace or Shiner.

This is a very common species, called in some localities Silver Roach, they abound in most of the smaller streams of this State and when fully grown attain a length of ten or twelve inches; they are well adapted to the Aquarium. In some special localities of New Jersey they are universally sprinkled over with small black dots. In the tributaries of the Passaic I have taken particularly large specimens of this fish, baiting with the common earth worm. 
Specific Character: Body elongated and compressed. Head with a series of mucous pores. Caudal, deeply emarginate, almost furcate. General color, whole upper parts silver white, tinged with blue on the back and upper portion of the sides. Pupil of the eye, black, encircled with a rather large luminous silver ring. Dorsal fin, quadrate with eight rays. Caudal, nineteen rays. Anal, nine rays, the second and third anterior ones longest. Ventrals, ten rays. Pectorals small and slender, sixteen rays. Ventrals in a line below the dorsal. Head smooth and flattened above. All the lower fins beautifully tinged with orange red.

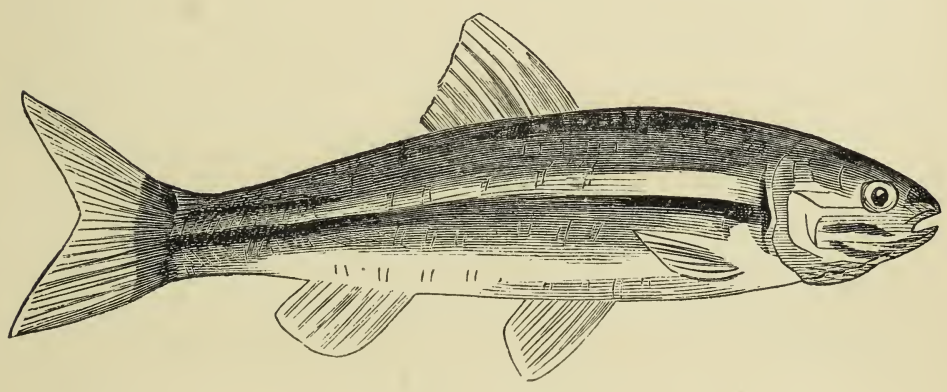

Leuciscus vittatus.-BANded Dace.-(De Kay.)

This is one of the best fish we have for the Aquarium, when small they are well adapted, being hardy, lively and handsome. They are much easier kept than the atronasus to which they are allied. In the Mohawk and tributaries they are very numerous, being gregarious in their habits. They are also numerous in the River Bronx, Westchester County, and indeed in many other streams in our vicinity. 
Specific Character: Body, sub-cylindrical, tapering ; head, flattened above; mouth, small, scaleless, and having a series of mucous pores; eyes, large; pupils of the same, black; irides, light brown; dorsal, with a golden dorsal stripe extending to the tail; upper part of the body, olive green; sides of the body with a conspicuous black stripe extending from the extremity of the head, to the base of the caudal, immediately above which is a yellow stripe parallel with it; abdomen silvery white, more or less tinged with salmon color; fins, pale yellowish; dorsal fin, quadrate higher than long, of nine rays, the first simple, second longest; caudal, deeply forked, nineteen rays; anal, rounded, eight rays; ventrals, eight rays; pectorals, fifteen rays.

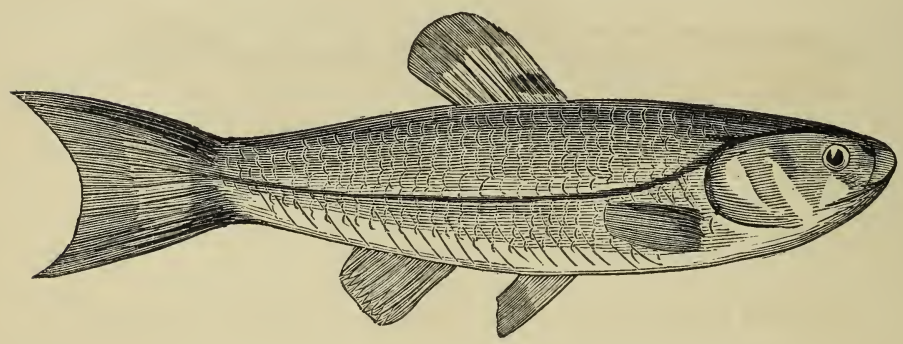

Leuciscus atromaculatus.-BLACK Headed DaCe.-(Mitchell.)

This is a very beautiful fish, and very common in the northern part of the State of New York. They attain a length of ten to twelve inches.

Specific Character: General form of the Leuciscida, except that the back is slightly depressed, anterior to the 
dorsal fin, and the mouth is larger than most of the Dace; general color, upper part of the body dark olive green, having a broad lateral band of a darker hue extending from the opercles to the caudal; sides of the body, rich golden yellow, shading into silvery white on the under parts; head, deep brownish black; lips, fleshy; opercles lustrous; pupil of the eye, black; irides, rich golden yellow; dorsal, rounded with nine rays and having a black spot near the base of the anterior ones; caudal, eighteen rays, branched in fives; anal, nine rays, light orange; ventrals, eight rays, light orange; pectorals, fifteen rays, light orange.

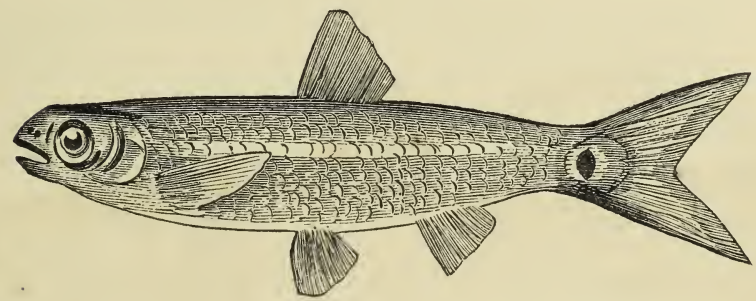

Leuciscus Hudsonius.-SPAwn EAter.-(DeWitt Clinton.)

Its name illustrates its habits; its beauty strongly recommends it to us for the Aquarium, but it should be kept alone, or at least should never be kept with smaller fish. It is a common species in the Hudson and many of its tributaries.

Specific Character: General color, brownish, darkest on the back; a lateral broad lustrous silvery band extends 
from the opercles to the base of the caudal, at which termination is a deep black conspicuous ocellated spot; pupils, black; irides, silvery white; two or three irregular shaped black spots betwixt the eyes and the extremity of the head; dorsal, eight branched rays, the anterior one longest ; caudal, ninteen rays ; anal, rounded ; ventrals, eight rays, one simple and seven branched; pectorals, pointed, fifteen rays; opercles, silvery, length six inches.

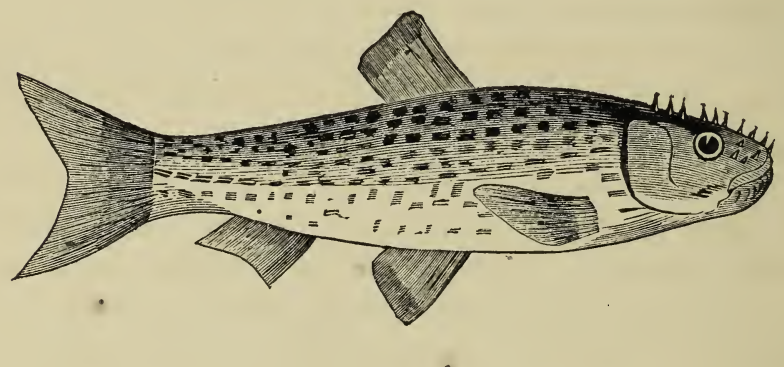

Leuciscus cornutus.-Horned DACE.-(Mitchell.)

This fish is more commonly known as the Red Fin. But few of our fluvial fishes excels this for beauty of marking or brilliancy of coloring. Many who read this can recall to mind reminiscensces of their boyish days, when at the old mill dam they have spent many hours of pleasure, catching the handsome red-fin; how patiently have they looked down into the pure stream in whose limpid waters these fish might be seen lying close to the rocky bottom, looking with a 
desiring yet distrustful eye upon the bait lowered down to allure them. Patiently has the young sportsman waited, buoyed up with eager hope, again almost despairing, lest his wished for prize would not yield to the tempting allurement of the bait; when at last this cunning fish yields to the temptation, darting suddenly at it, with what eagerness does he quickly raise it from the water, and with what admiration does he gaze upon its beautiful hues, more especially its crimson fins, that fairly glisten with vivid beauty in the rays of the sun.

They are esteemed as an article of food, and take the bait more readily immediately after a good shower of rain. As a general thing they are easiest taken with the hook early in spring.

Specific Character: Length, six to seven inches. General color, upper part rich blackish brown, with beautiful metallic reflections. Sides of the body, brilliant cupreous. Opercles, bright bronze gold color, tinged on the lower portion with deep crimson. Head furnished with a number of minute horns or protuberances of a tuberculous character, which are peculiar to this species, and suggested its name, cornutus-horned. Dorsal, dark brown, eight rays. Caudal, slightly emarginate, dark brown. Anal, nine rays. Ventrals, eight rays. Pectorals at the base, deep crimson, having fifteen rays. All the fins conspicuously margined with deep crimson. 


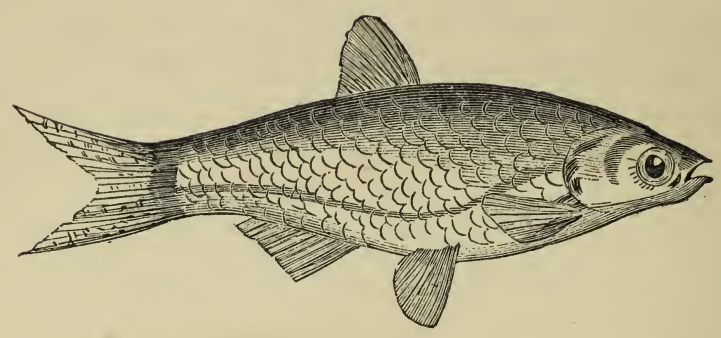

Abramis versicolor.-Bream.-(De Kay. $)$

This fish is known by numerous local names, such as Variegated Bream, Yellow-bellied Perch, Dace, Wind Fish and others. Why it ever received the name of Yellow-bellied Perch is not easily accounted for, as it has no character in common with the Perch; it might, however, be mistaken for a Dace. It received the odd name of Wind Fish, from the fact that during very windy weather when the surface of the water is considerably ruffled, these fish may be seen in hundreds, playfully gamboling on the surface. It attains a length of seven inches and is numerous in many of the streams on the eastern end of Long Island, also in the Hudson and several of its tributaries. They are esteemed as an article of food.

Specific Character: Upper part of the head, deep brownish black ; upper part of the body, silvery with metallic green and blue reflections, lower part of the same, golden. Pupils, black, irides, yellow. Caudal, nineteen rays. Anal, tinged 
with yellow, fourteen rays, one simple and thirteen branched. Ventrals, deep orange, nine rays. Pectorals, dull yellow, fourteen rays. Lateral line low and sharply curved downwards, the curve ascending from a line midway betwixt the ventrals and the anal fins, thence parallel with the lower line of the abdomen to its termination at the base of the caudal.

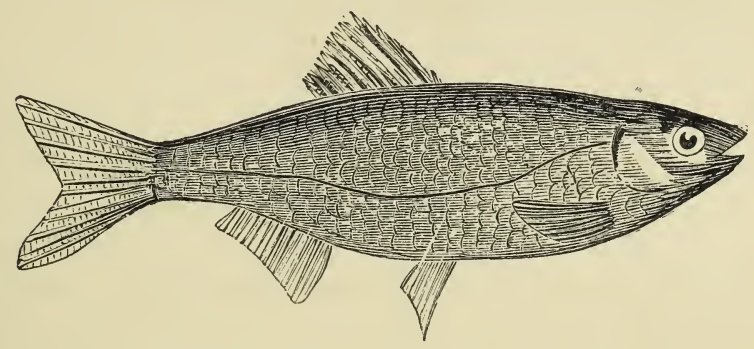

Stilbe chrysoleucas.-Golden DACE. - (Mitchell.)

This species is also called the New York Shiner. But little is known of this beautiful fish. I have taken a few of them in the Croton River, eight to ten inches, but this is an unusual size, six inches being an average size, the specimens I obtained in that river were more golden than usually found. I placed some fine specimens of this fish in the Aquaria of the American Museum, where they remained for a long time.

Specific Character: Upper part of the head, dark brown, with metallic green betwixt the eyes. Head very small. Upper part of the body, greenish yellow, sides pale gold, tinged with silver. Eyes, large and prominent. Dorsal, ten rays, the first short, but just protruding, second and third, 
progressively longer, the fourth, longest. Caudal, nineteen rays. Ventrals, ten rays, faint orange. Pectorals, fifteen rays, pale orange. Pupils, black; irides, pale yellow. Lateral line descending with a curve to a line with the ventrals; then the curve ascends parallel with the abdomen, terminating at the base of the caudal. This lateral line is placed rather low on the sides of the body, in a similar way to that in the Abramis versicolor.

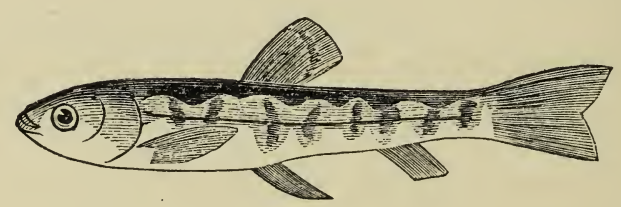

Baione fontanalis.-Pigny Trout.- (De Kay.)

This is one of our smallest fluvial fishes, seldom exceeding two inches in length. They frequent deep springs in Rockland, Orange and other counties in this State, where it is commonly known as the Trout Pig.

Specific Cinaracter: Body, slender, elongated. Eyes, large orbits surrounded by a series of mucous pores. General color, upper part of the body, blackish brown, sides of the body, silvery, with seven or eight black vertical bands, lateral line distinct, slightly curved downwards. Dorsal, in two parts, mottled with dark brown. Caudal, emarginate, nineteen rays. Anal, quadrate, nine rays. Ventrals, seven rays, one simple and six branched. Pectorals, twelve rays. All the fins, except the dorsal, tinged with orange on their outer margins. 


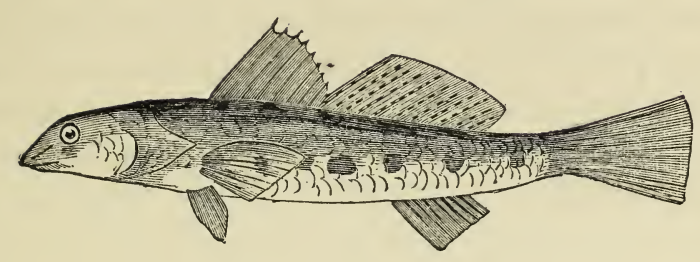

Boleosoma tessellatum. - Tessendated Darter.-(DeKay.)

This is another small fish, remarkable for its development of fins; the accompanying figure represents its adult size. Their habits are peculiar, they love to lie on the pebbly bottom of clear springs, perfectly motionless, awaiting their prey, which they seize with wondrous velocity, darting suddenly at them; this habit suggesting their name. If intended for the Aquarium, they should be handled with great care, as they are very tender, but live well after being properly acclimated to the tank. Length, two and a half to three inches.

Specific Character : Head prominent, body rounded, elongated. Caudal, rounded. Dorsals, largely developed. General color, olive brown, with five to seven oblong quadrate black spots on the dorsal line. Sides of the body, with a series of seven to nine black spots, forming a conspicuous interrupted lateral band. Dorsals, two. Anterior dorsal, nine spinous rays; posterior dorsal, fourteen branched rays, having the shafts of the same dotted with black. Caudal, seventeen rays, rigid, forming a powerful instrument. Anal, 
eighteen rays. Ventrals, six rays, one simple and five branched. Pectorals, thirteen rays. All the fins pellucid. Pupils, black ; irides, brownish.

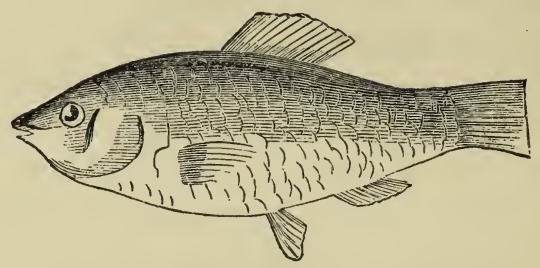

Lebias ovinus.-Sheep's Hrad Lebias.-(Mitchell.)

This is a marine fish, frequenting brackish waters during the spawning season, but I introduce it here because it can readily be acclimated to the Fluvial Aquarium, and is desirable on account of its small size, activity and brilliancy of coloring. Of all the fishes found in this latitude, none excel this little gem for brilliancy of hues; clothed in a rainbow robe of metallic colors, he may be seen full of his lively gambols, now basking in the rays of the summers' sun, or playfully leaping above the water's' surface, and suddenly disappearing when disturbed. They are easily obtained during the spring months, frequienting at that season the brackish waters of the numerous inlets of our coast, and will live well in a fresh water tank if properly acclimated to the change. Should you desire to introduce them into your Aquarium, if just taken from their native waters, it should be done gradually, by keeping them in the same water, gradually reducing it from day to day by adding fresh water to it, and in a weeks' time 
your Lebias can safely be introduced into the pure water of your Aquarium. The above figure represents an adult specimen of this fish.

Specific Ciraracter: Body, considerably resembling the Pomotis, being elliptical and compressed. General color, upper parts, dark metallic green, with numerous interrupted bars on the sides, running vertically. In the male, the throat and anterior lower parts are bright rufous. Sides of the body tinged with metallic blue. Pupils, black; irides, yellow. Fins, light brown, the caudal transparent at its extremity. Dorsal, eleven rays. Caudal, fifteen rays, even at the end and very short. Anal, ten rays. Ventrals, seven rays. Pectorals, fifteen rays.

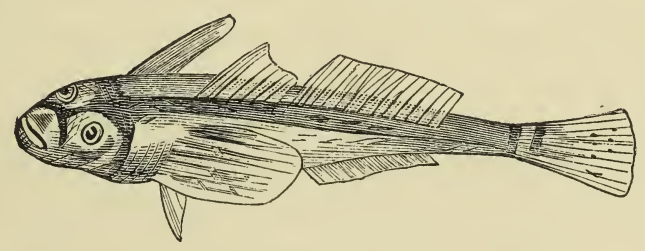

Uranidea quiescens.-Littre Star Gazer.-(De Kay.)

Never having met with this species, I introduce it here on the authority of Dr. De Kay, the figure and main features of his description I quote. "At present they are only known to inhabit Round and Pleasant Lakes, Herkimer County, New York. Its small size and peculiarity of form indicate 
it would be a desirable addition to our Fluvial Aquarium, but I am unable to speak from experience of its adaptability to the same. The peculiar habit they have of lying at the bottom of the lake perfectly still, with their head twisted as it were, looking upwards, is peculiar to this species, and suggested its name."

Specific Character: General color, olive brown, mixed with indistinct dark irregular spots. Head darker than the body. Lower parts nearly white. Dorsal, two ; anterior dorsal, seven simple spinous rays; posterior, dorsal, sixteen slender rays. Caudal, thirteen rays, tinged with orange. Anal, thirteen rays. Pectorals, ten rays, tinged with orange. Ventrals, very elongated, three slender rays. Eyes, large.

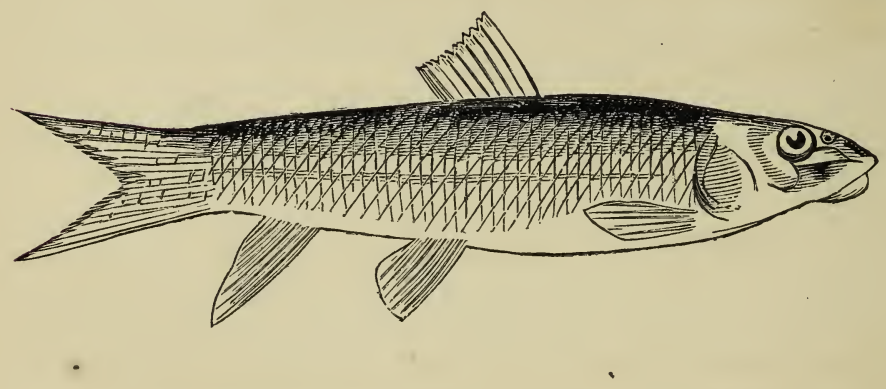

Catastomus pallidus.-Pate Sucker.-(De Kay.'

This common species has nothing of worth to recommend them to us; as far as my experience goes, they will not feed in the Aquarium. They frequent running brooks in company 
with the Leuciscus atronasus, Salmo fontanalis, Pomotis vulgaris, and Hydrargia diaphana.

Specific Character : Head, dark green, with metallic reflections on the cheeks. Back, pale bluish, intermixed with light yellow on the sides of the same. Under parts, white. Pupil of the eye, black ; irides, yellow. Dorsal, thirteen rays, dark brown, tinged with yellow. Caudal, eighteen rays, same color as the dorsal. Anal, eight rays, slightly tinged with yellow. Ventrals, nine rays, rich orange. Pectorals, sixteen rays, rich bronze.

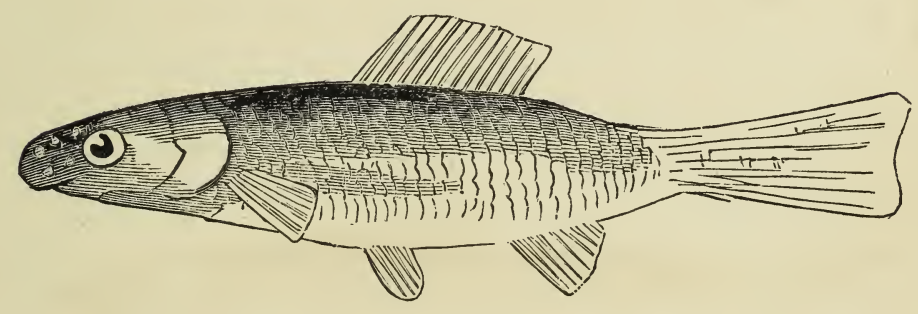

Catastomus tuberculatus-Horned Sucker.

This species inhabits running streams in the interior of the States of New York and New Jersey, and is commonly called Barbel, Horned Dace and Horned Sucker. Their greatest length is nine to ten inches.

Specific Character : Head, dark olive green; back and sides, green with rich purple and gold reflections; flanks tinged with yellow; abdomen, pale yellow, slightly tinged 
with flesh color; scales diamond shape; dorsal, fifteen rays, light brown ; caudal, ninteen rays, pale olive brown; anal fin, ten rays, dark dingy brown; ventrals, eight rays, light olive; pectorals, sixteen rays, their base flesh colored; betwixt the eyes and the extremity of the head are from three to five circular tubercules, hence its name.

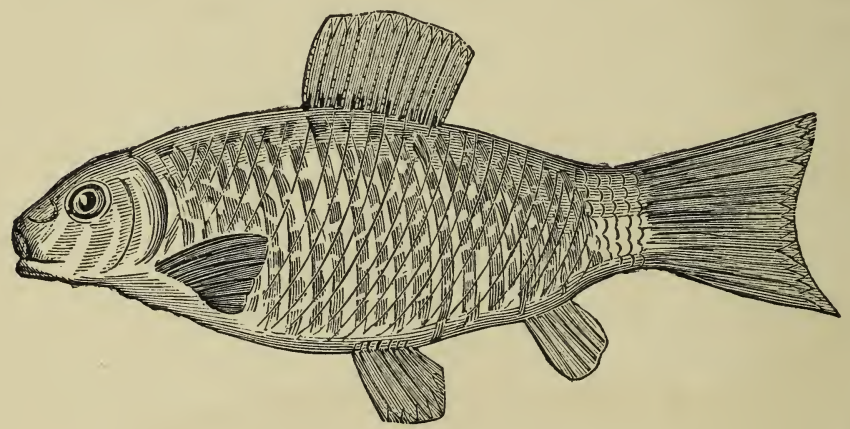

Labeo oblongus.-Brilliant Chubsucker.-(Mitchell.)

This handsome species I have found comparatively rare, but have occasionally taken them in the tributaries of the Passaic, New Jersey. Very common in the Susquehanna and other interior streams of Pennsylvania.

Specimic Character: Upper part of the body, dark olive green, shading into light cinnamon along the sides of the same; under parts, light cinnamon; a dorsal line of light cinnamon along the top of the back, and a pale lateral stripe 
along the sides; this lateral stripe is often indistinct, a fine specimen now before me has but the slightest indication of it; sides of the head, greenish blue of metallic lustre; dorsal, high, one simple and twelve branched rays, the upper half of the branched rays divided into eight branchlets each; shafts of the dorsal fin, cinnamon, webs, olive brown; caudal, emarginate, ninteen rays branched as in the dorsal; anal, pointed obtusely in the centre, eight rays of eight branchlets each, the middle rays longest, the shafts cinnamon tinged with red; pectorals, thirteen rays branched in fours, bright red, slightly clouded towards the tip; webs of the caudal, dark olive brown, shafts, cinnamon. This handsome fish attains to a length of ten to twelve inches.

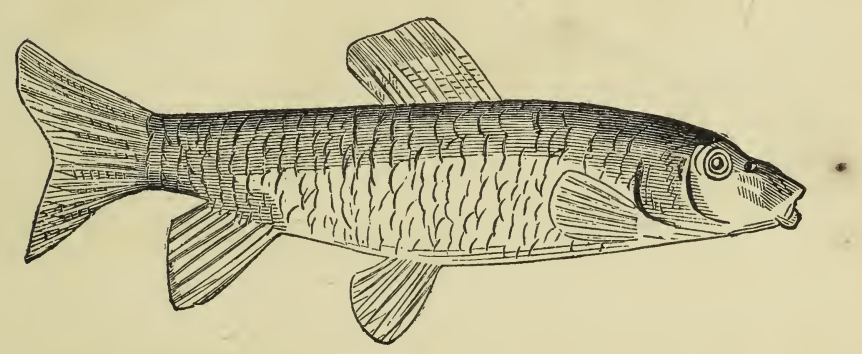

Labeo elegans._Elegant Chubsucker.-(DeKay.)

This is also a beautiful species, as indeed are all the Labeo, but they are a Genera as yet but little known. This fish is quite numerous in the waters of the interior of this State, and attain to nearly the same size as the oblongus. 
Specific Character : Body, deep and rounded; caudal, emarginate ; anal fin, largely developed; general color : head, bright green, body, bluish above, under parts nearly white, slightly tinged with pink near the abdomen; opercles, golden ; dorsal, twelve articulated rays, nearly quadrate; caudal, seventeen rays, tinged with rose red; anal, long; eight rays ; ventrals, nine rays; pectorals, fifteen rays, placed low on the body.

They frequent similar localities to the Catastoma tuberculatus, but are rare in the immediate vicinity of the City of New York.

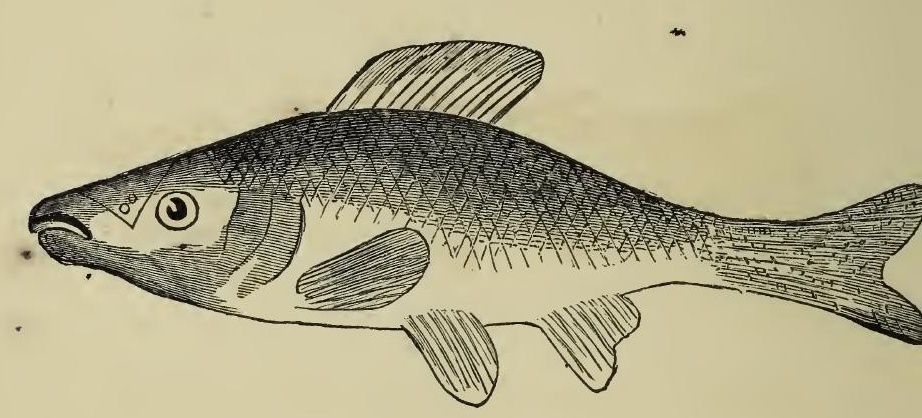

Labeo gibbosus._Gibbous Chubsucker.

This is likewise a numerous species in the interior and northern portion of this State. They attain a length of eight or nine inches and are one of the handsomest fish we have. 
Specific Cinaracter: Upper part of the body, dark blue with gold reflections, four or five dark vertical bands across the back; dorsal quadrate, bluish green, seventeen rays; caudal, eighteen rays tinged with brilliant carmine and violet; anal fin, deeply emarginate, almost furcate, tinged with orange, consisting of nine rays; ventrals, nine rays, reddish orange; pectorals, sixteen rays, reddish orange.

The next claiming our notice are the Pimelodus, Cat Fish; of this Genera we have three species found in this latitude, all of which are adapted to the Aquarium, when young.

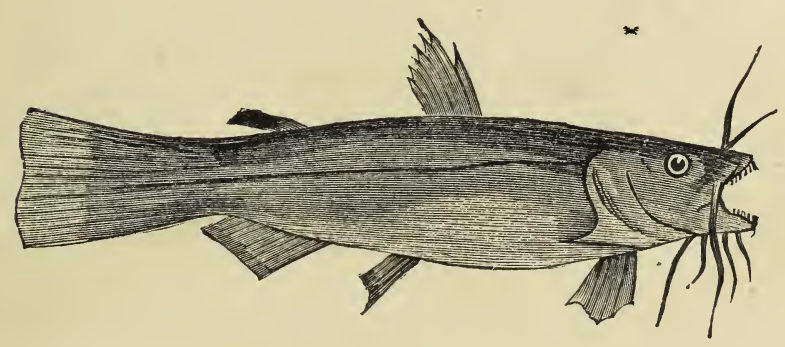

Pimelodus atrarius.-BLACK CAt Fish.-(DeKay.)

This is the smallest of the three species, rarely exceeding four to five inches in length. This is one of the species Capt. Mortimer and myself have introduced into private ponds in England; with what success they will become acclimated, time alone can determine. 
Specific Cínaracter: General color, deep black, fading into ash color beneath; dorsal, one acute spine and six soft rays; adipose dorsal, long and slender; caudal, seventeen rays, slightly emarginate, with the ends of the webs rounded; anal, long, twenty rays; ventrals, eight rays, small and feeble, the first one spinous ; pectorals, one spinous and seven branched rays. This species will breed in confinement, in the Aquarium.

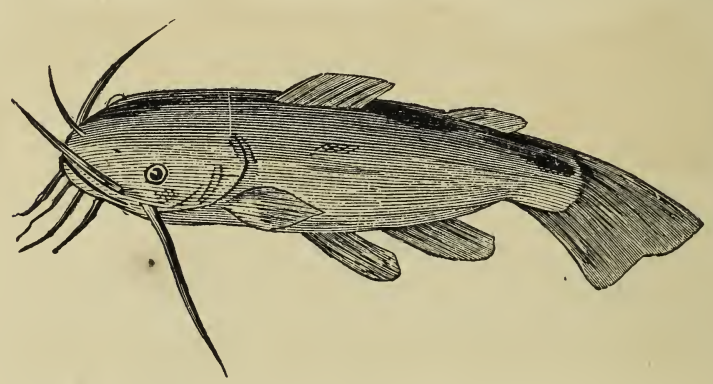

Pimelodus pullus.-Brown Cat Fish.-(De Kay.)

This is the largest species of the three, attaining a length of thirteen or fourteen inches, sometimes even exceeding this.

Specific Charactir: General color, dark brown, bluish white beneath. Fins, black, tinged with red. Pupil of the eye, black; irides, as in the other species, clear pearly white. Eyes, small, as in all the Pinelodus. Dorsal, one stiff acute 
spine serrated on its posterior edge, and five soft rays. Caudal, slightly emarginate, of nineteen rays. Anal, long, seventeen rays. Ventrals, eight rays. Pectorals set low, one sharp spine and seven other rays.

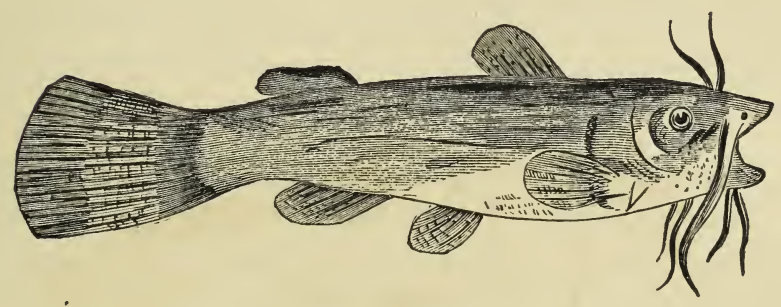

Pimelodus catus.-Common CAt Fish.-(Linnous.)

This species attains a length of eight to ten inches.

Specific Character: Head darker than the body, cheeks tinged with olive green, back and sides, dusky brown, lighter beneath. Pupils, black; irides, clear white. Fins, dusky. Dorsal fin, one spinous and six soft rays. Caudal, rounded, nineteen rays. Ventrals, eight rays. Pectorals, feeble, with one serrated spine and nine thickly crowded articulated rays.

$$
\mathrm{G}^{*}
$$




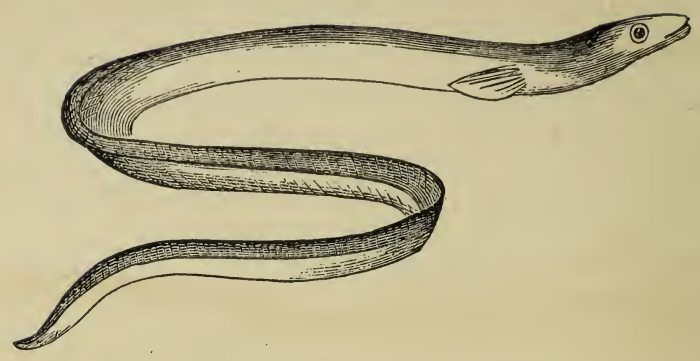

Anguilla tenuirostris.-Common Ees.-(De Kay.)

This very common species is universally known, they attain a length of $t w o$ to even three feet. If introduced into the Aquarium, the smaller they are the better, as they are destructive to other fish when they are large.

Specific Cuaracter: Head, small, tapering to the jaws. Dorsal, caudal, and anal fins united in one, consisting of three hundred and twenty to three hundred and forty rays. Ventrals, wanting. Pectorals, small, sixteen rays. Eyes, small. Lateral line, straight, but indistinct. Lower jaw longest.

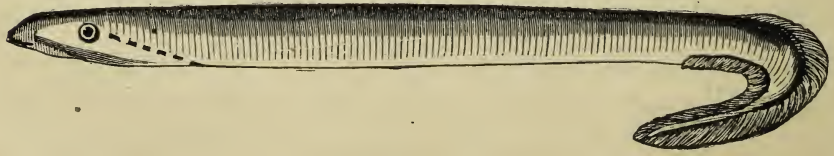

Ammocatus unicolor.-Plain Mud Lamprey Eel-(De Kay.)

This and the following species are introduced, on account of their small size, the representations being life size. They are. numerous in the interior of our State. 
Specific Criaracter: Upper parts, dusky brown, lightest beneath, anterior part of the head darkest. Dorsal and caudal united.

Peteromyxon appendix.-Syadl LaMprey.—(De Kay.)

Specific Character : Length, six inches. General color, dark lead, lighter beneath. Fins, light amber. Dorsal and caudal united. Anal, small, with a thread-like appendage to its anterior margin.

Of Genus Gasterosteus-Sticklebacks we have four species, found in the vicinity of New York; they are all suited to the Aquarium and are the only fish, except the Pimelodus, that will propogate therein. They have received the name of Sticklebacks from the fact of their backs being armed with acufe rigid spines.

The male Stickleback constructs a nest of refuse vegetation, having an entrance at either end, he industriously collects 
- the materials and cements it together by means of a gluten he exudes. In the Aquaria I have placed many pairs of these during the last four years, which have built their nests and reared their progeny. Much has been written on the loves of birds, poetry and song hath immortalized the theme, still nothing of the kind has appeared in regard to fishes. Still we have many evidences of conjugal love and paternal affection even amongst fish, and none display it more strikingly than the little Sticklebacks. During the season of love, the male assumes a special garb of richest colors, as if for the occasion, for at other seasons these brilliant hues disappear; at this nuptial period the whole under part of the Gasterosteus biaculeatus becomes the deepest crimson, whilst the upper parts are bright light blue; and small and insignificant as they appear, they are masters of their locality, their spirited bravery, being analagous to that of the Tyrannous intrepidus amongst birds.

The male Stickleback performs all the maternal and paternal offices, except the deposit of the spawn. Although this may be at variance with other writers' statements, yet it is nevertheless a fact, as I have had many excellent opportunities of occular proof.

The male constructs the nest in the first place, and after the spawn is deposited by the female, he impregnates it, and stands guard over it until the young appear, which usually occurs in about eighteen days. When they first appear, his vigilance and solicitude are redoubled, and for the first few days does not even allow the young to ramble from the nest, should any, however, succeed in eluding his watchfulness and escape from the immediate confines of the same, he instantly seizes them in his mouth, carries them back, and gently, as 
it were, blows them into the nest. After a few days, however, he allows them to roam, whither they choose. The female should then be taken from the tank, or else she will destroy the young fry. At this time the brilliant hues of the male gradually disappears, and in a short time he assumes his silvery metallic garb as before.

In the fens of Lincolnshire, England, the Sticklebacks are so numerous, the farmers use them for manure.

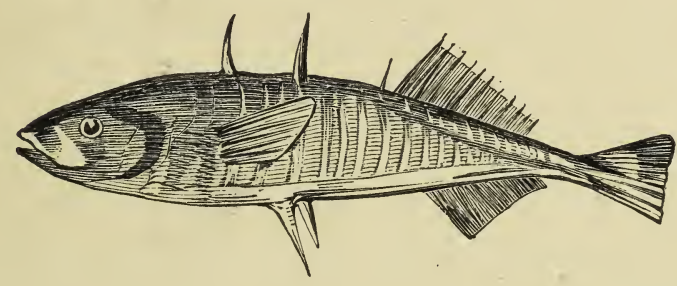

Gasterosteus biaculeatus.-Two Spined Stickleback.

This interesting fish, although the largest species of the genus found in this latitude, is only two to two and onehalf inches in length. The figure above represents its adult size. They frequent brackish and even fresh waters, and during the spring months, which is their spawning season, are quite numerous. I have many times taken them in the marsh inlets of the shores of Long Island and New Jersey, when I had to break holes in the ice; the males usually assume the nuptial garb (before spoken of) about the middle of March, and it disappears after the spawning season passes. 
All the Gasterosteus will thrive well in either a marine or fluvial Aquarium, but one thing is certain, the biaculeatus should never be kept in a tank with smaller fish; they are perfect tyrants, annoy all their companions, continually hunting the smaller fish, and as often as possible nipping their fins; but whilst they annoy small fish in this manner, they do not appear materially to molest large ones.

Spectfic Character: Upper part of the body, rich olive green tinted with yellowish shades, and irregularly marked with irregular shaped dark blotches; sides of the body and under parts, metallic white, the sides considerably sprinkled over with minute black dots; pupils, black; irides, silvery slightly tinged with yellowish orange; sides of the body mailed with thirty vertical plates, the first commencing in a line directly. above the pectorals, these plates extend twothirds down the sides of the body; ventral plate, lanceolate posteriorly; a faint lateral line, rather high, extending to the base of the caudal; dorsal, armed with two long acute spines anterior to the fin; dorsal fin, one short spine and eleven simple rays, upper margin of the fin even, webs transparent; caudal fin, small, twelve branched rays; anal, one short spinous ray slightly curved, and eight transparent branched rays; ventrals, wanting, but with two sharp long spines in their place, these spines have their anterior margins smooth, posterior serrated, with two small spinous processes at their base, anterior side of the spines, bright orange for two-thirds of their length; pectorals, ten transparent rays. 


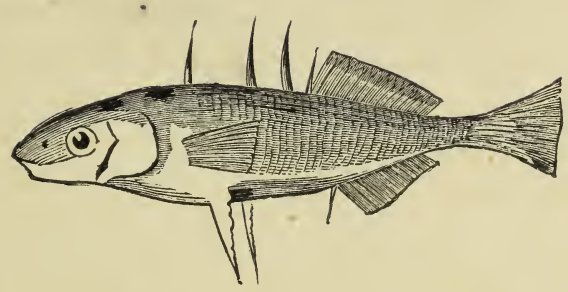

Gasterosteus neoboracensis. New York Stickleback. (DeKay.)

The New York or Three Spined Stickleback, is closely allied to the Gasterosteus trachurus, or Three Spined Stickleback of Europe. Habits and character of this species similar to the biaculeatus.

Specific Character: Length, two to two and one-quarter inches; eyes, large; general color, upper part of the body bluish slate, shading into silvery white on the sides, and under part of the body; dorsal, with three acute spines anterior to the fin; dorsal fin, even, one spinous and thirteen simple rays ; caudal emarginate, small, thirteen slender rays; anal, with one curved acute anterior spine, and twelve branched rays, fin slightly emarginate; ventrals, wanting, represented by two long acute stiff spines, having their posterior edge serrated; pectorals, small and feeble, with eleven rays. The above figure represents the adult size. 


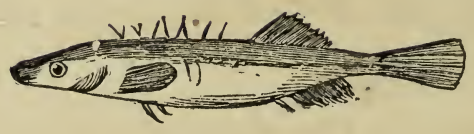

Gasterosteus occidentalis-TeN or Many SPINed StickleBACKS. - (De Kay.)

This species differs much in form from either the biaculeatus or the neoboracensis, the body being more elongated, much more slender, and tapering towards the posterior extremities very greatly. Their habits differ too from those species, as this one can be kept with impunity amongst small fish, agreeing well with them; they usually ascend higher up the fresh water streams than either of the above mentioned species.

Specific Character: Length, one and a half to two inches. Body, long and slender. Upper part of the body, dark brown, variegated by dark blotches. Lower part of the body, silvery white. Lateral line slightly curved, very fine but distinct. Pupils, black; -irides, bright reddish brown. Head small, elongated; eyes, prominent. Dorsal with ten, sometimes only nine small acute spines, anterior to the fin, these spines are set alternately right and left. Back, with metallic green reflections. Dorsal fin, one stiff spine and seven soft branched rays. Caudal, thirteen branched rays. Anal, one stiff acute spine and eight branched rays. Ventrals wanting. Ventral spine, acute, Pectorals well developed, eleven branched rays. 


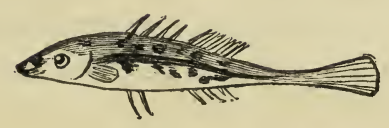

Gasterosteus quadracus. Four Spined Stickneback. (Mitchell.)

This is the smallest of the four species herein mentioned, and ascends the fresh water streams higher than any of the others; they are excellently well adapted to the Aquarium, in fact are preferable in this respect to either of the other species. They seldom, if ever, exceed two inches and a quarter in length, usually averaging about an inch and threequarters.

Specific Character: Body, deeper than the occidentalis, but equally attenuated at the base of the caudal. General color varies considerably ; usually they are olive green, mottled with dusky brown on the upper parts, lower parts silvery. From three to four spines on the dorsal, (usually four,) anterior to the fin; dorsal fin, one spinous and twelve articulated rays. Caudal, thirteen slender rays. Anal, with one recurved acute spine and ten softrays. Ventrals wanting. Ventral spines with their upper half deep red. Pectorals, small and feeble, twelve slender rays. Dorsal spines set alternate, the first or anterior one in a direct line over the ventral spines. Lateral line extends from a point parallel with the eye, then slightly ascends, then descends with a considerable curve, again rising towards the caudal, thus forming a waved line. Below the lateral line the sides of the body are marked with abbreviated blackish bands formed of innumerable minute black dots. 
Storer describes another American species having seven dorsal spines, which frequents the fiesh waters of the State of Maine, this he has named the Gasterosteus mainensis.

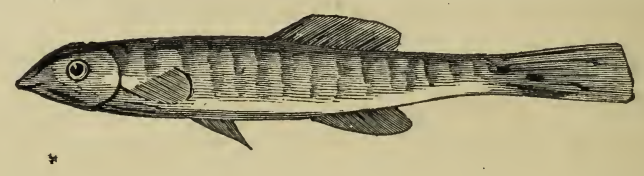

Hydrargia diaphana.-Transparent Mrnnow.

This is the only species of minnow acceptable to the Aquarium; it is exclusively a fresh water species, frequenting trout streams, and usually found in company with the Leuciscus cornutus, atronasus, Pomotis vulgaris, appendix and other fluvial fishes. In the Aquarium this species never interferes with their companions, unlike the salt water minnows, presently to be noticed.

Specific Character : Head flattened above, body elongated and diaphanous. General color, upper part of the body, greenish olive, under parts, nearly white, sides with sixteen vertical bands, inconspicuous; opercles tinged with brilliant metallic blue and green. Eyes, large and prominent. Pupils, black; irides, silvery, with an interior golden ring immediately surrounding the pupils. Dorsal situated posteriorly, of thirteen rays. * Caudal, even, eighteen branched rays. Anal, small, being only half the size of the dorsal, of twelve branched rays. Ventrals, slightly developed, pointed, 
of six rays. Pectorals, rounded, eighteen rays. In some localities I have found this species more or less sprinkled with small black dots. Length, two to. three inches.

Two other species of Hydrargia are described by Dr. De Kay, both of which are numerous in the fresh waters of the northern part of the State of New York, viz :

First, the Hydrargia atricada (De Kay), Champlain Minnow, common in Lake Champlain and its tributaries.

Second, the Hydrargia multifasciata (De Kay), Many Barred Minnow; inhabits Saratoga Lake, etc., and is quite numerous.

These species, having no peculiarities of color or form to recommend them to us, and not being found within the environs of New York, it is unnecessary further to notice them.

The salt water minnows are included under Genus Fundulus, but none of them can be kept with other fish, as they constantly annoy them. They will, however, live very well in fresh water, as they naturally frequent brackish and even pure waters. The species found in our Bay and inlets are:

First, the Fundulus viridescens, or Big Killifish.

Second, the Fundulus zebra, or Barred Killifish.

Third, the Fundulus fasciatus, or Striped Killifish.

Many other species of fluvial fishes are found in various localities of the Union suited to the Aquarium, but the fortyfour species figured and described in this chapter embrace all those found within a circuit of twenty-five or thirty miles of the City of New York. This number affords ample variety for all our purposes, and includes many that are but little known to the general public. Amongst those enumerated are a few that cannot be obtained within the limits prescribed above, such as the Uranidea quiescens, Little Star Gazer (page 69), and the Lepisosteus bison, Buffalo Bony Pike 
or Alligator Gar (page 37). These extra species are introduced for their peculiar character of structure or prepossessing appearance.

With this brief explanatory remark we close the outline of the fluvial fishes adapted to the Aquarium.

The following is a synopsis of the various authenticated species of fluvial fishes native in the United States, east of the Mississippi River. Many of these are suited to the Aquarium, but not being found within our limits have not been introduced in the preceding chapter.

Order First.

\section{SPINE RAYED FISH.}

FAMILY PERCIDA.

Genus Perca.-Percir.

Of this Genus I have introduced two species for the Aquarium, on pages 39 and 41, the remaining American species are, viz :

Perca Granulata, (Cuvier.) Rough Headed Yellow Perch. Cuvier says he received it from the State of New York, particular locality not given.

Perca acuta, (Cuvier.) Sharp Nosed Yellow Perch. Lake Ontario.

Perca gracilis, (Cuvier.) Slender Yellow Perch. Skeneatelas

Lake, New York. This is a small species and would be an acquisition to the Aquarium.

Perca nebulosa, (Haldeman.) This is a very small species, described by the author as only two inches in length, - discovered in the Susquehanna.

Perca minima, (Haldeman.) The same remarks are applicable to this species. 
Genus Labrax.-BAss.

Of the native Bass, found in fresh water, I have introduced two species appropriate to the fluvial Aquarium; see pages 42 and 43. The other American fresh water Bass are as follows: Labrax albidus, (De Kay.) White Lake Bass. Lake Erie. Labrax notatus, (Richardson.) Ten Spotted Bass. St. Lawrence River.

Labrax multilineatus, (Cuvier.) Many Striped Bass. Wabash River, Indiana.

Genus Aphredoderus.- Spineless Perch.

But one American species is included in this Genus, this is the one described on page 44 .

Genus Huro.

Of this Genus but one species is known, the Huron nigricans, (Cuvier.) The Black Huron. Lake Huron. Genus Boleosoma.

Of this Genus one species is described on page 67. Genus Leucioperca.-Pike Perch.

Leucioperca americana, (Cuvier,) Yellow Pike Perch or Pike, found in the lakes of the interior part of New York. Leucioperca grisea, (DeKay), Gray Pike Perch; same localities. Leucioperca canadensis, (Griffith's Cuvier), Canada Pike Perch; River St. Lawrence.

\section{Genus Centratrchus.}

Of the Centrarchus, one species is quoted for the Aquarium. Two other species of this Genus are found in the Northern $\mathrm{H}^{*}$ 
part of the State; the rest of the American species are confined to the Southern and Western States. Our species quoted is the :

Centrarchus oneus, Common Fresh Water Bass. Page 45.

The other New York species are the :

Centrarchus fasciatus, Black Fresh Water Bass; lakes of Western New York.

Centrarchus obscurus, (De Kay.) Obscure Fresh Water Bass;

Onondaga Lake.

The Southern and Western species are as follows :

Centrarchus pentacanthus, (Cuvier.) Wabash River, Indiana. Centrarchus hexacanthus, (Cuvier.) Wabash River, Indiana. Centrarchus sparvides, (Cuvier.) South Carolina. Centrarchus irideus, (Cuvier.) South Carolina. Centrarchus gulosus, (Cuvier.) South Carolina and Mississippi. Centrarchus virides, (Cuvier.) Carolinas.

\section{Genus Pomotis. - Pond Fish.}

Of the Pomotis, three species are figured in the foregoing pages ; the rest of the American species are all found farther south.

Pomotis ravaneli, (Cuvier.) South Carolina.

Pomotis holbrooki, (Cuvier.) South Carolina.

Pomotis incisor, (Cuvier.) New Orleans.

Pomotis gibbosus, (Cuvier.) Charleston, S. C.

Pomotis solis, (Cuvier.) New Orleans and New Jersey.

Pomotis catesbei, (Cuvier.) Philadelphia.

These species are all undoubtedly adapted to the Aquarium. Closely allied to the Pomotis are the Bryttus. 
Genus Bryttus.

Three species of this Genus are described; none of them extend North of Pennsylvania, however.

Bryttus punctatus, (Cuvier.) South Carolina.

Bryttus reticulatus, (Cuvier.) South Carolina, Bryttus unicolor (Cuvier.) Pennsylvania to South Carolina.

FAMILY TRIGLIDE.

That peculiar fish, the Uranidea quiescens, on page 69, belongs to this family, so also do the Gasterosteus-Sticklebacks.

Genus Gasterosteus.

I have introduced four of this Genus, on pages 81 to 85 , inclusive; the extra limital species are the Gasterosteus concinnus, (Richardson.) Nothern Regions. Gasterosteus mainensis, (Storer.) State of Maine. Gasterosteus niger, (Cuvier.) Newfoundland.

\section{FAMILY SCIENIDA.}

\section{Genus Corvina.}

Of the Corvina none are found in our vicinity, the following are the American species:

Corvinà oscula, (Leseur.) Lake Sheepshead. Lake Erie and Ontario.

Corvina richardsonii, (Cuvier.) The Malasheganay. Great Northern Lakes.

Corvina grisea, (Leseur.) White Perch of Ohio. Ohio River.

All the preceding species belong to the Spine Rayed Fishes. 


\section{Order Second. AbDominal.}

\section{SOFT RAYED FISH.}

This order of fishes have the ventrals placed behind the pectorals and not attached to the humeral bone.

FAMILY SILURIDA.

Genus Pimelodus.- $\mathrm{C}_{\mathrm{AT}}$ Fish.

This is a very numerous Genus of Fishes, embracing a large number of species, all but four, however, are confined to the Southern and Western States. Of the four exceptional ones, three are found within our vicinity and are described in these pages. See pages 75,76 and 77 .

The following are the extra limital species.

Pimelodus nigricans. Great Lake Cat Fish. Lake Ontario, etc. Pimelodus cœnosus, (Richardson.) Lake Huron.

Pimelodus albidus, (Leseur.) Delaware River. Pimelodus Lemniscatus, (Leseur.) Southern States.

Pimelodus furcatus, (Leseur.) Fork Tailed Cat Fish. Ohio River.

Pimelodus punctulatus, (Leseur.) Louisiana.

Pimelodus aneus, (Leseur.) Ohio River.

Kirtland describes the following additional species as natives of the Ohio River.

Pimelodus cerulescens. Blue Cat Fish.

Pimelodus cupreous. Yellow Cat Fish.

Pimelodus pallidus. Channel Cat Fish.

Pimelodus nebulosus. Mud Cat Fish.

Pimielodus zanthocephalus. Small Black Bull Head.

Pimelodus flavus. Young Cat Fish. 
It is probable some of the above will yet prove to be only varieties of well defined species.

Amongst the native fishes, none are more peculiar than the species known to inhabit the little river Styx, which flows through the interior of that subterranean wonder, the Mammoth Cave, in Kentucky. The peculiarity in this species is the fact of its obscure location, being local to the cave, not found elsewhere. The other peculiarity is the fact of their being blind. Dr. DeKay, who first described this species, confessed himself at a loss where to place it, and instituted a new Genus under the name of Amblyopsis, and included it among the Siluridæ, for want of a better place.

\section{Genus Amblyopsis. - (DeKay.)}

\section{Amblyopsis speleus.-Bund Fish of Kentuckr.-(DeKay.)}

- The fact of its being blind, was for a long time doubted, but subsequent investigation has substantiated it as a fact. This is the only instance of the kind known in Ichthyology.

\section{FAMIIY CYPRINIDE.}

To this Family we are indebted for the chief variety for our Aquariums, all of the species being more or less suited to it.

\section{Genus Cyprinus.}

Cyprinus carpio, Common Carp. This species was introduced from Europe in 1831, by Henry Robinson, Esq., of Newburg, N. Y. It is now a common fish in the Hudson.

The well known and universally admired Gold Fish, or Golden Carp (page 31) belongs to this Genus. The next in order are the Labeo, Chubsucker. 


\section{Genus Labeo.}

Three species of this Genus (pages 72, 73 and 74) are introduced in this chapter as appropriate for the tank; the other extra limital species are the :

Labeo Cyprinus, (Leseur.) Long Finned Chubsucker. Susquehanna, Pa.

Labeo esopus, (DeKay.) Round Backed Chubsucker. Northern and Western part of New York.

The Chubsuckers are all very brilliant colored fishes, none exceeding them in beauty. Next are the Catastomus, or Suckers; of this Genus two species are mentioned for the Aquarium (pages 70 and 71.)

\section{Genus Catastomus. - Sucker.}

Catastomus communis, (Leseur.) Common Sucker, very generally distributed.

Catastomus oneida, (De Kay.) Oneida Sucker, Oneida Lake, N.Y. Catastomus aureolus, (Leseur.) Mullet Sucker. Lake Ėrie. Catastomus nigricans, (Leseur.) Black Sucker. Lake Erie. Catastomus macrolepidotus, (Leseur.) Large Scaled Sucker. Delaware River.

Catastomus longirostris, (Leseur.) Long Nosed Sucker. Vermont. Catastomus maculosus, (Leseur.) Spotted Sucker. Maryland. Catastomus elongatus, (Leseur.) Missouri Sucker or Black Horse.

Ohio River.

Catastomus vittatus, (Leseur.) Striped Sucker. Philadelphia. Catastomus duquesnii, (Leseur.) White Sucker. Ohio River. Catastomus sucellata, (Lacepede.) South Carolina. Catastomus maxilingua, (Leseur.) Little Sucker. Delaware.

Of these the vittatus and maxilingua are best suited for the Aquaria, the former being only two inches in length, the latter four inches. 


\section{Genus Leuciscus.-DACE.}

"Of the Leuciscus, seven species are introduced, as found in our vicinity, all suited to the Aquarium; pages 54 to 62 , inclusive; the extra limital species are the following:

Leuciscus pulchellus; (Storer.) Beautiful Leuciscus, Roach Dace or Couzin Trout, habitat, the Eastern States.

Leuciscus argenteus, (Storer.) Silvery Dace. Massachusetts. Leuciscus corporalis, (Mitchell.) The Corporaleon. Upper part of the Hudson and it tributaries.

Leuciscus elongatus, (Kirtland.) Tributaries of Lake Erie; this is a very beautiful species, very desirable for the tank.

Leuciscus dissimilis, (Kirtland.) Same locality.

Leuciscus biguttatus, (Kirtland.) Ohio River.

Leuciscus cephalus, (Kirtland.) Big Headed Chub. Ohio.

Closely allied to the Leuciscus is the Bream, belonging to Genus Abramis. See page 64 .

Next to this is the Genus Stilbe, one species of which is described on page 65 .

\section{Genus Lebias.}

This Genus embraces only two species, both of which are very diminuitive and acceptable to the Aquarium; one of these is described on page 68 ; the extra limital species is the Lebias ellipsoides, (Leseur.) Habitat Florida.

Next follow the Fresh Water Minnows forming

Genus Hydrargira.

One species of Hydrargira is described in this work on page 86 ; the extra limital species are: 
Hydrargira atricada, (DeKay.) Champlain Minnow. Lake

Champlain.

Hydrargira ornata, (Leseur.) Ornamented Minnow. Delaware River.

Hydrargira nigrofasciata, (Leseur.) Black Striped Minnow. Rhode Island.

Hydrargira multifasciata, (DeKay.) Many Barred Minnow. Saratoga Lake.

Closely allied to the Hydrargira is the

\section{Genus Molinesia.}

Molinesia latipennis, (Leseur.) Ponds in Louisiana.

FAMILY ESOCIDAE.

Genus Esox.

This Genus embraces the Pickerel and Pike, two of the former being described on pages 35 and 36 . The extra limital species are the :

Esox estor, (Leseur.) The Muskellonge or Pike, Lakes of Northern and Western New York.

Esox tredecem radiatus, (Mitchell.) The Federation Pike, Lakes of Northern and Western New York, called the Tredecum radiatus, or Federation Pike, from the fact that four out of the five fins have thirteen rays in each, the original number of the federal compact of States.

Esox phateratus, (Say.) East Florida.

- Genus Pimeoma.-Pickering.

We have but one species of this Genus, described on page 38. 


\section{FAMIILY SALMONIDA.}

Genus Salmo.

This Genus comprises the Trout and Salmon, and the species are most numerous in cold latitudes; British North America is particularly rich in this class of fishes. One species, the well known and highly esteemed Brook Trout, Salmo fontanalis, is figured on page 34 of this work. The extra limital species are the:

Salmo erythrogaster, (De Kay.) Red Bellied Trout. Lakes of Northern and Western New York, etc.

Salno confinis, (De Kay.) Same habitat as the preceding. Salmo amethystus, (Mitchell.) Mackinaw Salmon. Great Northern Lakes.

Salmo salar, (Linn.) Common Sea Salmon. River St. Lawrence.

Salmo Canadensis, (Griffilh's Cuvier.) Canada Salmon. River St. Lawrence.

\section{Genus Baione.}

This Genus embraces but one species, a beautiful and diminutive fish closely allied to the Trout; see page 66 .

Genus Coregonus.

The species of this Genus are all large, and frequent the waters of the more northern sections of the United States, the following are the species:

Coregonus albus, (Leseur.) White Fish. Great Upper Lakes. Coregonus clupeiformis, (Mitchell.) Common Shad Salmon. Same localities.

Corregonus otsego, (Dewitt Clinton.) Otsego Salmon. Otsego Lake.

Coregonus harengus, (Richardson.) Lake Huron. 


\section{Fanimy Clupidz.-Genus Amia.}

Amia occidentalis, (De Kay.) Western Mud Fish. Amia calva. Dog Fish "or Lake Lawyer. Lake Erie.

Family Sauride.-Genus Lepisosteus.

This is a peculiar Genus of Fishes, the one found within the limits of our State, is introduced in these pages, (see page 37 ,) the extra limital species are as follows:

Lepisosteus platyrhincus, (DeKay.) Flat Nosed Bony Pike. Florida.

Lepisosteus longirostris, (Cuvier.) Lake Huron.

Order Fourth.- Apodar. Fish.

FISH WITHOUT VENTRAL FINS.

Fàmily Anguildide.-Genus Anguilla.

The common Anguilla tenuirostris is described on page 78; the extra limital species are the Anguilla rostrata, (Leseur.) Beaked Eel. Cayuga and Geneva - Lakes, New York.

Anguilla macrocephala, (Leseur.) Bull Head Eel. Saratoga lake. Sub-Class second.-CARTILAGINOUS FISHES.

Order Third.- crcLostonir.

Family Petromyzonide.-Genus Petromyzon.

Of the Petromyzon one species is described on page 79 , the extra limital species is the Petromyzon argenteus, (Kirtland.) Habitat the Big Miami River, State of Ohio.

Genus Ammoccetus.

Of the Ammoccetus, one species is described on page 78 , the extra limital species is the Ammoccetus bicolor, (Leseur.) Colored Mud Lamprey. Connecticut River. 


\title{
CHAPTER VII.
}

\author{
THE ANIMAL LIFE OF THE AQUARIUM.
}

\section{THE AMPHIBIANS.}

The Amphibians suited to the Aquarium.

Tue Amphibious animals are those that live part of the time in water and a part of the time on land, being sub-aquatic. The species suited to the Fluvial Aquarium are quite limited in number. Of these I propose to introduce all the species found within the neighborhood of the City and County of New York.

The first of these claiming our attention are the Water Turtles, comprising but two species suitable to our subject.

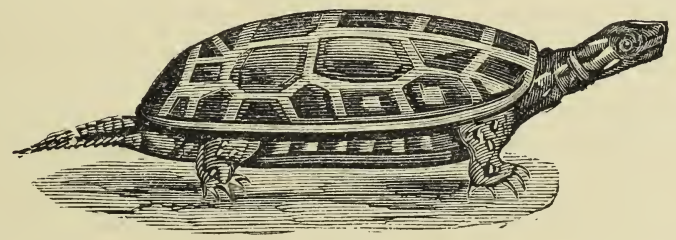

Chrysemys picta.-Painted Water Turtle.

The family to which this and the following species belongs and their congenors, the marine turtles, and land turtles, have been very elaborately described by Prof. Agassiz, who has devoted three quarto volumes to their history, dwelling very minutely upon their nidification. 
The Painted Water Turtle has a wide geographical range, being generally found throughout the Atlantic States, and has always been prized as a desirable curiosity for the tank. They live well in confinement, requiring however to be regularly fed. For the Aquarium, the smaller they are the better; the accompanying figure represents its size when nearly two years old. If used larger than this they annoy the fish. They shed their shell periodically, and in their native waters lie deeply buried in the mud during the winter months. During warm sunny days they may be seen resting upon an old $\log$ or stump of a tree, basking in the rays of the sun. Their sense of hearing and seeing are very acute and they must be approached with caution to insure capture. When disturbed from their resting place, they quickly slip into the water, in that case it is futile to attempt their capture. When in confinement, they eat lean beef with avidity, they are likewise fond of the common house fly.

Specific Character: Upper shell, highly convex, elliptical, divided into thirteen central plates and twenty-five marginal plates. Lower shell also elliptical, slightly convex, narrower than the upper, protruding in front a little beyond the upper shell. This under shell is divided longitudinally into two divisions, each division sub-divided into six plates, the centre two being the largest, and the two anterior ones smallest; the two centre plates on each side extended on their outer margins and uniting with the upper shell. Head and neck, deep black, distinctly marked with bright red and saffron yellow stripes. Cheeks striped with bright red, and having four yellow irregular blotches on the upper part of the same. Eyes, small but keen; pupils, black; irides, yellow, with four black spots on their disc. Throat conspicuously 
striped with yellow. Nostrils, small, rounded. Front of the head protruding to an obtuse point. Head and neck, as in all the family, capable of being drawn completely in, and concealed by the elastic skin of the folds of the cover; this neck covering beautifully striped with bright red. Legs and feet covered with small tough scales, handsomely variegated with black and bright red. Upper shell deep brownish black, sometimes tinged with dark olive brown; in some, nearly black; divisions of the upper plates of the same broadly margined with dull yellowish brown. The twenty-five marginal plates of the upper shell, ornamented with red in their centres; under edge of these plates extending to the body of the animal, bright red, marked with black. Lower shell, orange brown, each plate with a grooved line on its inner surface, parallel with the margin of the same. Feet furnished with five toes, having long sharp curved claws or nails. Feet striped with red to the base of the claws. Claws, black at their base, whitish at their tips. Plates of the upper shell with a series of lines running parallel with the sections of the same. A narrow stripe of yellowish brown extends longitudinally down the centre of the upper shell. Tail small, pointer, compressed towards the extremity, black, striped with red and yellow, laterally. 


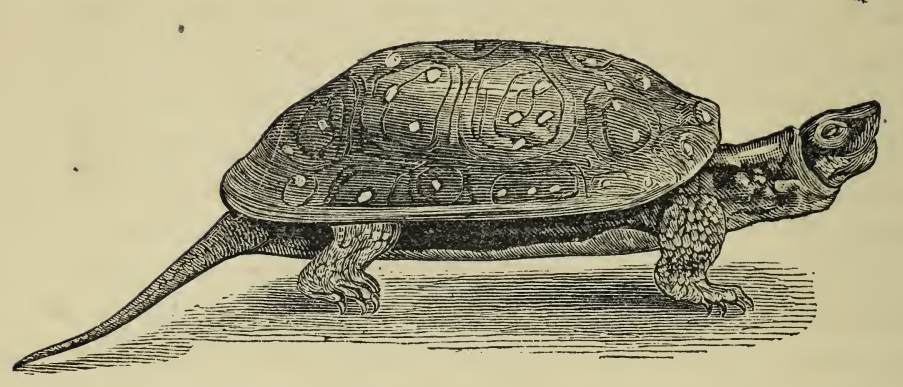

Emys punctata.-Spotted Water Turtle.-(Schneid.)

This is also a handsome species, and the same general remarks are applicable to it as regards its habits, as were made in the case of the "picta," with this addition - the punctata passes more of its time on dry land during the summer, often crossing large fields in quest of food which consists of various insects.

Specific Character : Upper shell highly convexed, elliptical, and hollowed in at its anterior end. The upper shell consists of thirteen plates on its rounded surface, the four centre ones sextagonal; and twenty-four small marginal plates surrounding the others. Under shell divided into twelve plates by a longitudinal line along the centre of the shell. Head flattened above as in the picta; broadest at the eyes. Nose, obtuse; nostrils, small and rounded. Pupils, black; irides, hazel brown. Upper part of the head, black, unspotted; neck, black, spotted with bright yellow; throat, 
blackish brown; elastic skin of the neck, black. Legs and feet, black, scaly, thickly spotted with orange; feet scaled to the base of the claws; claws, acute, curved and black. Upper shell, deep blackish brown, thickly spotted with yellow dots, varying in number in different individual specimens; in some very few in number, in others completely sprinkled; about twelve on the largest plates being the maximum. Lower shell varies in color, in some almost entirely black, whilst in others the rufous brown predominates. Tail, pointed, scaly, black spotted with yellow; under the base of the same, orange red. Upper and lower shell chiefly connected by the centre plate on each side.

As in the picta, they make a peculiar hissing noise when handled.

The next family of Amphibians claiming our attention are the Tritons; of these only one species is really adapted to the Aquarium, although the other species can be reared in the tank if plenty of resting space be furnished them above the surface of the water. The same is also applicable in regard to the Salamanders, hereafter to be mentioned.

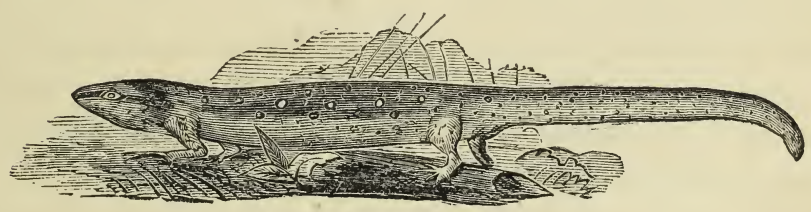

Triton millepunctatus.-Many Spotted Triton or Newt.

The many spotted Triton or Newt, commonly but erroneously called Lizard, is an exceedingly numerous species, generally distributed throughout the country. They are 
most numerous in small ponds, and few stagnant waters are without them. During the winter months they hybernate, burying themselves deep in the mud. Their eccentric motions render them an interesting feature of the Aquarium; they require introduced food, worms or beef answer well; if not fed they annoy the fish contained in the tank.

Specific Character : Head, flattened above; body, elongated, rounded; dorsal ridge, sharp. Eyes, small but prominent. Nose, obtusely pointed; nostrils, small, rounded, distant. Legs and feet compressed; toes, five, centre ones longest; toes without claws or nails. Tail greatly compressed, fully as long as the body, upper margin of the same more or less undulated.

General color : whole upper part of the body and sides, olive green, varying in shades of color in individual specimens; in some reddish brown, in others yellowish brown. Whole under side and flanks, yellow, thickly spotted with black dots. Upper part of the body and sides also sprinkled with black dots, and having a row or series of crimson spots encircled with black on their sides. Division of the color of the sides and the light yellow of the under parts abrupt, not being blended. Pupil of the eyes, black brown, tinged with orange red. Tail same color as the upper parts and thickly sprinkled with black dots. Legs and feet, yellowish brown, sprinkled with black dots to the extremity of the toes.

The next species of Triton to be introduced to your notice, as I before remarked, are not so aquatic in their habits as the millepunctatus, yet they can be kept in the tank, if necessary resting places are provided for them. 


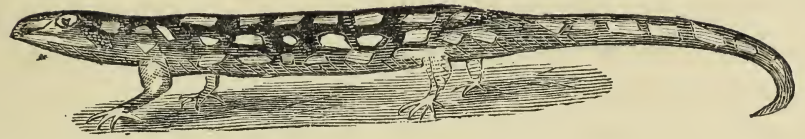

Triton tigrinus.-TIGER TrITON.-(Green.)

This is a very beautiful species, comparatively rare. Length, six to seven inches. Body, elongated, rounded. Tail compressed from its base to the tip. General color, lustrous bluish black, beautifully marked with large, conspicuous irregular spots of yellowish, over the whole animal.

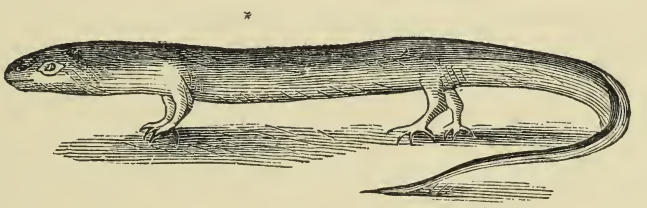

Triton niger.-Black or Dusky Triton.-(Green.)

This species can be kept in the same manner as the tigrinus; they should all be regularly fed.

Specific Cinaracter: Length, five to six inches. Body, elongated, rounded, tail as long as the body, compressed. General color, upper part of the body and sides, uniform dark brown or black, under part of the body, lighter. Sides, with inconspicuous small white spots. Toes, unusually long. 
Closely allied to the Tritons are the Salamanders; these animals are much more terrestial than aquatic, yet they may be kept in the same manner, as alluded to in the case of the Triton tigrinis or Triton niger.

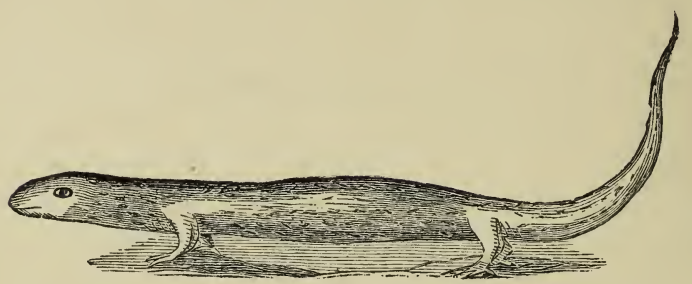

Salamandra rubra.-Red Salamander.

*

This is a beautiful species. Specific character: general color, red, spotted over with roundish spots, most numerous on the head. Length four to five inches.

The Salamanders not being so aquatic as the Tritons, I have introduced but one species. The whole of the American species will be found in the annexed list; this is furnished because some persons might be desirous of keeping these singular creatures, if so they must bear in mind that they can hardly be considered sub-aquatic; they will however live for a short period immersed in water.

Salamandra sypmmetrica. Symmetrical Salamander. Found in the vicinity of New York and all the Atlantic States Salamandra erythronata. Red Backed Salamander, common in numerous localities in New Jersey. 
Salamandra picta, (IIarlan.) Painted Salamander. Massachusetts to Pennsylvania.

Salamandra subviolacea, (Barton.) Violet colored Salamander.

Found from Maine to Maryland.

Salamandra cirrigera, (Holbrook.) Louisiana.

Salamandra sinciput albida, (Green.) New Jersey.

Salamandra gutta lineata, (Holbrook.) Carolina.

Salamandra auriculata, (Holbrook.) Georgia.

Salamandra talpoidea, (Holbrook.) South Carolina.

Salamandra quadrimaculata, (Holbrook.) Four Spotted Salamander. Pennsylvania to Georgia.

Salamandra haldemani, (Holbrook.) Pennsylvania to Virginia. Salamandra glutinosa, (Green.) Blue Spotted Salamander.

Found from Massachusetts to Pennsylvania.

Salamandra coccinea. Scarlet'Salamander.

Salamandra bilineata, (Holbrook.) Striped Backed Salamander.

New York, Ohio and Pennsylvania.

Salamandra granulata, "(Holbrook.) Granulated Salamander.

Pennsylvania.

Salamandra longicauda, (Green.) Long Tailed Salạmander.

New York, Pennsylvania and Ohio.

Salamandra fasciata, (Green.) Blotched Salamander. Massachusetts to Ohio.

Salamandra salmonea, (Holbrook.) Salmon Colored Salamander. Massachusetts, New York and Vermont.

The extra limital Tritons are the following:Tritons porphyriticus, (Green.) Gray Spotted Triton. Southern States.

Triton ingens, (Green.) New Orleans.

Triton Jeffersoni, (Green.) Jefferson's Triton. State of Pennsylvania. 
Having reviewed the Water Turtles, Tritons and Salamanders, the next claiming our notice, is the Astacus Bartoni, or American Cray fish.

Genus Astacus.- Cray Fish.

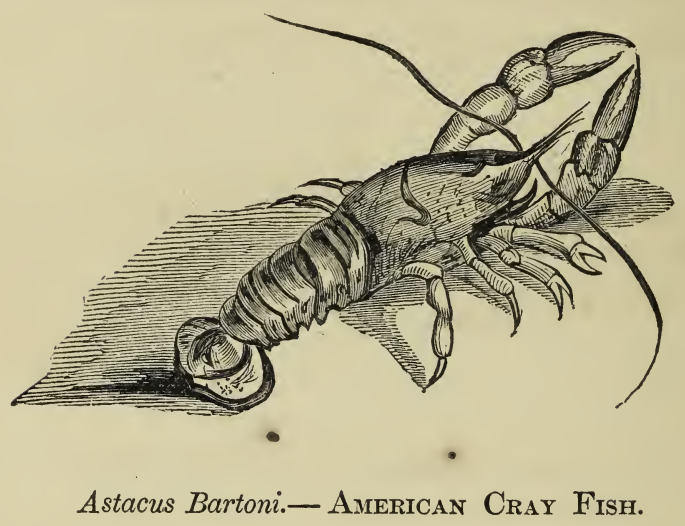

This species is introduced in this place, because it is of amphibious habits. It is closely allied to the British Astacus fluviatilis, only the fluviatilis attains a much larger size, and is highly esteemed by epicures. Our Cray Fish inhabits clear running brooks, such as Trout frequent. They burrow in holes or hide under rocks and stones, and to a considerable extent re nocturnal in their habits. At night they often emerge from their hiding places and crawl from one stream to another in search of food. If kept in the tank, they require, like all the amphibious creatures, a resting place 
above the surface of the water ; they will live for a considerable time out of water ; I have repeatedly kept them in this way four and even five days at a time. Like their congenors of the ocean, (the lobster,) they shed their shell periodically, and the opportunity afforded of observing this curious and interesting change of dress, will well repay any trouble experienced in keeping them in confinement.

The last of the Amphibians to be noticed are the Tadpoles.

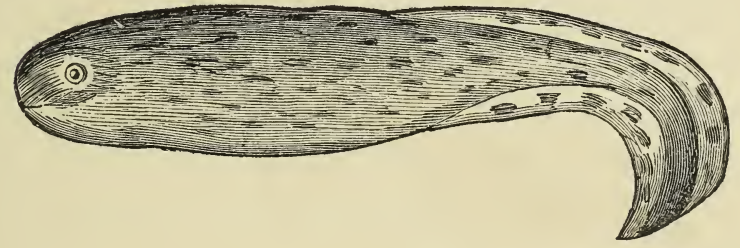

Tadpole of the Rana pipiens. - Bull FroG.

These are extremely numerous, found in almost every pond throughout the country, they are well adapted to the tank, are lively and live well. No tank should be without a few tadpoles; their transformation to the frog is interesting and worthy of attention. All frogs in their tadpole state are strictly aquatic, but in their mature state are amphibious. Should you keep your tadpoles until they assume the perfect form of the frog, your tank must be covered with net work to prevent their jumping out, and a resting place above the waters' surface provided, as. in the case of the rest of the amphibians heretofore mentioned.

K 


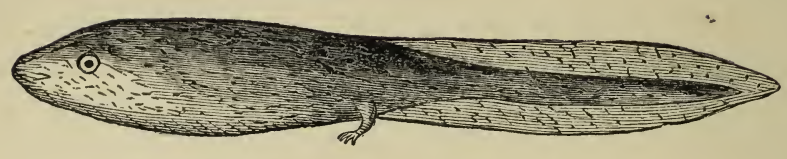

Tadpole of the Rana fontanalis. - SPring Frog.

The remarks upon the pipiens are applicable to this and all the other species of the Genera. I have deemed these two examples sufficient to illustrate the American species, any of which are worthy of a place in the Aquarium during their Tadpole stage. 


\section{CHAPTER VIII.}

ANIMAL LIFE OF THE AQUARIUM.-(Continued.)

\section{THE FLUVIAL SHELLS AND INSECTS.}

Fluvial Shells and Insects adapted to the Tank-What Insects to avoid.

OF the Shells the Unios are the most conspicuous for the tank, they are extremely hardy, and live well in confinement. One of the easiest procured in our locality is the Unio Complanatus, a figure of which is appended.

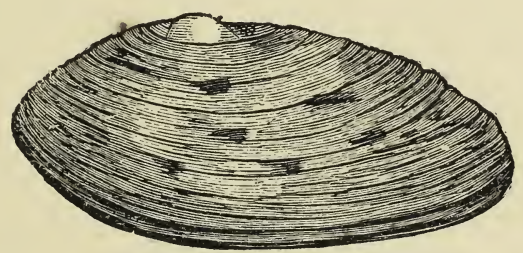

Unio complanatus.

This is one of the handsomest marked species, found in our vicinity, variegated as it is with green, and rich brown, and beautifully striated. Our fresh waters furnish us with a large number of Unios. 
Of the smaller shells the most useful are the Planorbis and Physas. Of the Planorbis the best one is the Planorbis trivolvis, shaped somewhat like a cornucopia. The Planorlis, Physas and Limneas act as scavengers to the tank, and no Aquarium should be without them.

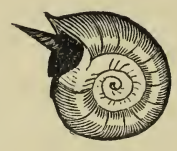

Planorbis trivolvis.

This is an exceeding numerous species in many of the ponds in our vicinity. General color, dark brown; left margin of the lip below the plane of the transverse diameter. Six other species of Planorbis are described in our Fauna, two of the best of these six for the tank are the bicarinatus and armigerus. Of the Limneas seventeen species are described by Dr. DeKay as American, all of which could be used for the Aquarium. Another Genera of small shells are the Cyclas; of these, six species inhabit our State, viz:

Cyclas similis, dubia, parteumeia, rhomboidea, elegans and edentata.

Of the Physa nine species are described from our State. These are excellent for the Aquarium, and are readily procured; the best species is the heterostroplia. 


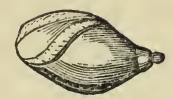

Physa heterostropha.

General color, greenish, the oldest ones being darkest; when young, usually tinged with yellow; inside of the lip reddish. Whorls, four. Aperture of the shell nearly oval. Very common in sluggish streams.

The insects suited to the Aquarium are but few in number, amongst the multitude of Aquatic Insect life; indeed, great care should be taken as to the species placed in the tank. Very many of them are highly destructive, and in addition to the species recommended for use, I shall point out those to be carefully avoided. One of the best of the Aquatic Coleoptera for the Aquarium is the Hydropholis tri-ovalis

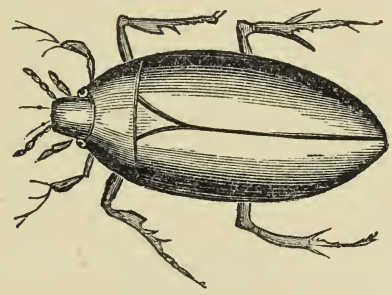

Hydropholis triangularis.

This fine insect represented as above, its natural size, is perfectly harmless for the Aquarium. The body is highly concave, and its color very dark greenish black, under part $\mathrm{K}^{*}$ 
of the body luminous. The family in fact to which this species belongs furnishes us with nearly all the Coleoptera suited to the Aquarium. Although often met with they are not so numerous as the Dytiscus, the most rapacious of all the Aquatic Coleoptera.

Another fine species of this Genus, is the Hydropholis ovalis, this is much rarer than the above, and equally as desirable.

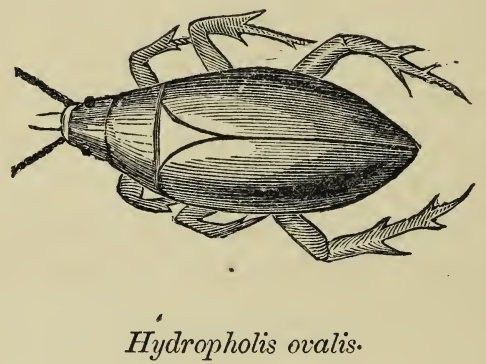

This is one of the rarest of the Aquatic Insects, as for the tank, it is one of the best. In general color, it resembles the triangularis, but it varies in its form. Two other species of Hydropholis will be introduced; first, the glaber.

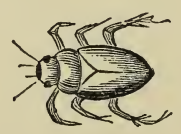

Hydropholis glaber.

This is a small black species, with no great peculiarity. 


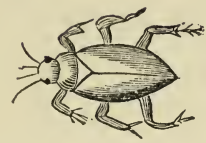

Hydropholis lateralis.

This species is a little larger than the glaber.

Be sure never to introduce any of the Dytiscida into your tank, they are carnivorous and very voracious, and very destructive to small fish. Neither would I recommend the Notanecta or Boat Fly, because I know they injure the fish. Avoid also any of the larrce of the numerous species of Libellulidee or Dragon Flies.

The Gammarus minus or Fresh Water Shrimp are perfectly harmless and form excellent food for your fish, nearly all species devouring them greedily. 


\section{CHAPTER IX.}

THE VEGETATION OF THE AQUARIUM.

The Vegetation of the Aquarium-The plants best adapted to the same.

This is most important, for upon its character rests the health of your finny tribe; we have around us a large variety of excellent aquatic plants suited to the purpose, that liberate oxygen freely, thus purifying the water. Independent of the necessity of their presence in the Aquarium for their revivifying powers, they are essential for their ornamental beauty; nothing can be more beautiful than a tank in good order, well supplied with animal and vegetable life, the varieties of color displayed in the vegetation form a picture worthy of admiration.

In selecting plants for the Aquarium, care should be taken that they are perfectly fresh, and that the roots are entire; in some of the Afyriophyllums, small fibrous roots proceed from the lower portions of the stem: it is from this fact that the small sprig of Myriophyllum will grow when detached from the main stem. Even this plant, however, grows stronger and more luxuriant when the radical roots are retained.

I propose briefly to review, the various species adapted for the Aquarium.

First of all we have the beautiful group of plants known 
to botanists as the Utricularias; the name derived from Utricula, a little bottle, in allusion to the peculiar shape of the air vessels. These beautiful plants are furnished with innumerable utriculo or air vessels, which, being filled with air, sustain the plant, floating on the surface of the water. The Utricularia is an early spring plant, making its appearance often before the ponds are entirely clear of the ice; the first indications of its growth are minute green globular balls, somewhat like a pea; as soon as these balls burst open, or the least sign of their opening takes place, they immediately rise to the surface of the water and rapidly grow. Some of the Utricularias extend like a rope, a length of three to five feet; when it has arrived at its greatest perfection, the utriculo bursts open, causing the plant to sink to the bottom, and soon rapidly decays. The color of the Utricularias is very light green, and no aquatic plant found in the United States exceeds it in delicate beauty. Of the Utricularias, fifteen species are described as natives of the United States.

1. The Utricularia inflata. This species grows in ponds from Maine to Florida and west to Ohio. It bears four or five yellow flowers together upon a scape. Utricula, innumerable. Stem very long and branched, upper leaves in whorls of fives and sixes, lower leaves, dissected. Spur of the flower nearly as long as the corolla, striate and emarginate. Corolla, yellow, the upper lip, broadly ovate, lower lip, trilobed. Flowers in August.

2. The Utricularia purpurea. Purple Utricularia. This species can readily be distinguished from the others by the large bright purple flowers they bear. Grows in ponds from Maine to Florida and north-west to Wisconsin. Flowers in August. 
3. The Utricularia intermedia. This species is distributed in ponds throughout Canada and the upper tier of Northern States and west to Wisconsin. Chiefly distinguished from the other species by having leafless branches bearing the utriculo. Upper lip of the corolla entire, and twice as long as the palate. Flowers during June and July.

4. The Utricularia Robbinsii. A local plant described by Dr. Wood as growing in swamps in Uxbridge and Northbridge, Massachusetts.

5. The Utricularia striata. Striped Utricularia. This plant is not of a floating character, the stem being slightly attached to the soil by minute fibrous roots. - It is easily distinguished from the others by its striated flowers. Leaves sub-divided into many divisions. Flowers, usually two, large and having the upper lip three lobed of a bright yellow color, the centre lobe striated with red; lower lip crenate with dark spots upon the palate. Grows in stagnant ponds on Long Island and is generally distributed throughout the Atlantic States, south to Florida. Flowers in June.

6. The Utricularia longirostris. This and the two following species are confined to the Southern Atlantic States.

7. The Utricularia biflora.

8. The Utricularia bipartita.

9. The Utricularia clandestina. This plant differs from the others in the fact that the corolla never opens, and is the only species of the Genus having this peculiarity. It grows in ponds throughout the Atlantic States, from Massachusetts to New Jersey. The stem attains a length of two feet, bearing many air vessels. Leaves all submerged. Flowers, two to three on a slender scape, also solitary on slender axillary pedicels among the leaves on the stem. Flowers in July. 
10. The Utricularia gibba. This is a minute species found in pools from Massachusetts to Carolina. Stem, short, dichotomus and filliform. Leaves, hair-like, and with few utriculæ. Scape, one to two, flowered. Corolla, yellow, upper lip, emarginate; lower, subtrilobate. Spur gibbous, hence its name.

11. The Utricularia minor. Found in ponds throughout Canada and the Northern and Eastern States, and west to Wisconsin. In this the corolla is of a pale yellowish color, and very widely expands. Scape, three to six, flowered. Upper lip of the corolla, ovate, emarginate, as long as the palate; lower lip, obovate, flattened, much longer than the spurs. Flowers in July.

12. The Utricularia vulgaris. This is the most common, but yet the most beautiful species of the Genus. It is found abundantly throughout the United States and Canada, growing with great luxuriance in stagnant ponds; the small green balls of this plant usually appear early in March, often before the ponds are clear of ice. If a few of these are collected and placed in the Aquarium they open and grow with amazing rapidity; in ten days I have had this plant attain a length of two feet in this manner. The vulyaris grows to a great length, and can often be obtained five feet in length, sometimes even seven feet. Stems very branching. Leaves, numerous. Utriculæ with a fringed valvate aperture. Flowers, alternate, showy yellow, scape, simple, rising out of the water and bearing five to eleven flowers. Lower lip of the corolla with a projecting palate, striped with brown. Flowers during June and July.

13. The Utricularia resupinata. This plant, as far as known, is confined to the ponds of Massachusetts.

14. The Utricularia subulatata. This is a minute plant, 
growing in swamps of the Atlantic States, from Canada to Florida. Stem slightly attached to the soil by minute fibrous roots; plant, creeping; leaves, few and linear. Scapes few, filliform, one to five, flowered. Flowers, yellow; upper lip of the corolla, ovate. Flowers in June.

15. The Utricularia cornuta. This plant is found in ponds and swamps from Canada to Florida, and south-west to Louisiana. Stem, rooting, tall, erect, with two to five subsessile flowers. Corolla, large and yellow; upper lip, small, emarginate; lower lip, very broad, trilobed; palate, very prominent; spur, subulate, acute and spreading from the corolla. Flowers from June to August.

From the above fifteen species, several beautiful varieties can be selected for the Aquarium, they include some of the most delicate of our aquatic plants, none excelling them in this respect for beauty.

The next family of plants claiming our attention as suitable to the Aquarium, are the Myriophyllums. Of these hardy aquatics we possess six species. The following are their specific characters from which their jdentity may be determined. The Myriophyllums are perennial in their character.

In the tank the Myriophyllums will last for an indefinite period. They can be propogated from the smallest offshoot. When not entirely irnmersed $\mathrm{in}_{*}$ water, the leaves do not develope in that pinnate form that is natural to them when completely immersed; this is the case during dry seasons, when many of the ponds dry up. The leaves not immersed in water, that do not assume this pinnated form, have their margins more or less serrated.

1. The Myriophyllum verticillatum. Water Millfoil. This species is one of the most abundant, occuring in ponds, 
and sluggish waters from Canada to Florida, and from Maine to California. Leaves in verticills of threes. Flowers sometimes perfect, small, green, axillary with conspicuous floral leaves, which are pectinate, pinnatifed and longer than the flowers. Flowers in July and August.

2. The Myriophyllum spicatum. Spiked Water Millfoil. This plant has likewise a wide geographical range, extending from the New England States south and west to Arkansas. The slender stem of this plant usually grows in deep water, it is branched and very long. Leaves composed of innumerable hair like segments, always submerged. Leaves in verticills of threes, all pinnately parted. Flowers in terminal, nearly naked, spikes, floral leaves entire, ovate, shorter than the flowers; petals, broadly ovate; stamens eight. Flowers small greenish, blossoms in July and August, and is caducous.

3. The Myriophyllum heterophyllum. This is a rare plant, growing in sluggish waters from Canada to Florida. Stem, thick, branching. Leaves, very various, lowest floral ones pectinately divided; leaves in verticills of fives; spikes, terminal, nearly naked. Floral leaves, ovate, lanceolate and serrate. Petals, oblong; stamens four to six. Flowers firom June to September.

4. The Myriophyllum scabatrum. Leaves pinnatifed in whorls of fours and fives. Floral leaves linear, and pectinately toothęd. Flowers, small, verticillate and axillary. Flowers in July. This plant occurs in ponds and sluggish streams throughout the Northern and Eastern States.

5. The Myriophyllum ambiguum. Floating Millfoil. This is a numerously leaved species. Stem, long floating. Submerged leaves pinnate, with capillary segments, middle 
ones pectinate, upper ones linear, petiolate toothed or entire according to the depth of water they grow in. Flowers very minute, floral leaves linear. Grows in ponds and sluggish streams from Pennsylvania to Massachusetts. Flowers in July, the blossom is axillary, solitary and sessile.

6. The Myriophyllum tenellum. The rhizome or stem long, prostrate and creeping, sending up erect branches almost leafless. Flowers, purplish white, small, sessile and alternate. Floral bracts minute, alternate, entire, obtuse and slightly longer than the flowers. Petals linear, stamens four. Flowers in July. Grows in ponds and swamps from New York to Newfoundland.

Next in importance to the Myriophyllums is the Ceratophyllum. Of this Genus we have but one species, the Ceratophyllum demersum, or Hornwort, commonly called Mare's Tail. This is one of the best plants we have for the Aquarium, its dark luxuriant foliage contrasting well with the lighter greens of the Utricularias and Nyriophyllums. In its native waters it is annual, but in the tank is perennial. One peculiarity of this plant is the remarkable short period it will remain fresh and green if taken from the water and exposed to the atmosphere, almost immediately withering, differing in this respect from all other aquatic plants. During the summer season, if much of this plant be kept together, it heats the water to such an extent, that the whole mass soon becomes fermented; the plant sloughs away and in a few days becomes a putrid mass; such is the case in the localities where it is found. During the summer months it grows so prolific, and in such masses, that when it arrives at full maturity, it soon shows signs of decay, and towards the latter part of autumn, melts as it were away, leaving scarcely a vestige 
of its former luxuriance. In the Bronx River, Westchester County, New York, it attains to great perfection, so also in many of the tributaries of the Hackensack, Passaic and Raritan rivers in New Jersey. I have never observed its presence in still waters.

Stem, long, slender, branched, floating ; leaves in whorls of eights. Foliage, dark green when fully developed, bright green when young. Flowers greenish, very minute, axillary and solitary.

The next plant claiming our attention is the Anacharis Canadensis, or Water Thyme. This plant of all others is the most prolific. I have had young shoots, in the Aquarium during spring, to grow twelve to fifteen inches in three days. Although in its native waters it is an annual, like the Ceratophyllum, it becomes perennial in the tank, and continues to increase if left undisturbed, soon requiring thinning out. Originally it was peculiar to this continent, but some specimens sent over to a Professor in Cambridge University, England; where inadvertently thrown into the River Cam, and from this trifling incident it became naturalized there and has now spread throughout many of the fresh waters of England, (where it is known as Water Thyme, and in some instances has impeded the navigation in the canals, occasioning inconvenience and expense in clearing them.

Stem long, branched; leaves, lanceolate in whorls of threes. Foliage, light bright green.

Our botanists describe but one species of this plant, but there are two varieties found in the sluggish streams of Hudson County, New Jersey, which, upon closer investigation, may prove to be distinct from the canadensis. These varieties do not attain that strength of growth the canadensis 
does, the stem is much more fragile, the leaves much smaller, and more linear, darker colored, and the plants are not so hardy.

The next plant to call your attention to is, and always has been considered, the best ærator or liberator of oxygen known; the Valisneria spiralis, or Tape Grass. It received its Generic name in honor of Valisnei, an eminent Italian Naturalist, who gained great repute by his excellent writings upon Botany and Entomology. This is an interesting plant in different respects, first, as being the best purifier of water, second, as being the first plant ever used in an Aquarium, by Dr. Lankaster in 1841, (as spoken of in the first chapter;) and lastly, as being an excellent object under the microscope to view the circulation of the sap.

This plant is exceedingly abundant in the Delaware and Raritan Canal, in fact is troublesome to the navigation of the same; it grows also luxuriantly in the Hudson, at Newburg, New York. The male and female flowers grow on different plants, the female flowers are borne on long spiral foot stalks, the male ones on straight, short flower spikes. It can readily be propogated in the tank by off shoots, and will last indefinitely.

The next in value for the Aquarium are the Potomogatons, Pond Weeds. Of these we have fifteen species found in this vicinity, as follows :

1. The Potomogaton compressum, distinguished by its compressed stem and linear, obtuse leaves. Stem, one to two feet long, branching, flattened and green. Leaves, closely sessile, margins parallel, ending in an abrupt point; peduncle bearing from five to twenty-five flowers. Flowers in July. 
2. The Potomogaton Tuckermani. Stem, filliform, with capillary branches; leaves, few, all capillary. A very delicate species.

3. The Potomogaton natans. Broad leaved Pond Weed. Stem, slender, one to three feet long, branched. Leaves, oblong, or elliptical, ovate on long petioles, spikes rather dense. Flowers in July and August. Grows in ponds and sluggish streams. New England to Wisconsin.

4. The Potomogaton heterophyllus. Stem, round and slender ; filliform, branching. Floating leaves, lanceolate or oblong, five to seven veined. Grows in ponds and sluggish streams.

5. The Potomogaton diversifolium. Varied leaved Potomogaton. Stem, filliform, branching; upper leaves, ovate and lanceolate, five veined; lower ones, sessile, filliform, alternate. Upper leaves only rising to the waters' surface, these are acute on hair-like petioles. Flowers in July.

6. The Potomogaton hylridus. Stem mostly simple, very slender, one to three feet long. Floating leaves, elliptic oblong, very slightly veined, longer than their petioles; submerged leaves long, linear, sessile. Spike, cylindrical, dense ; seeds coiled into a ring. Grows in ponds and slow streams. This is a very handsome species for the Aquarium.

7. The Potomogaton fluitans. Stem, simple or branched, several feet long. Floating leaves opposite, oval, lanceolate, acute at each end, shorter than the petioles, submerged leaves larger than the floating ones, lanceolate, sessile, strongly veined, wavy, thin, slightly reticulated, not shining. Pedicills thickened, cylindric. Spikes, dense, flowered. Flowers in August. Grows in deep clear water. New York to Canada. 
8. The Potomogaton lucens. Easily distinguished by its large pellucid leaves. Leaves, large, shining, oblong, lanceolate, flat, very pellucid, conspicuously cross-veined. Spikes, long, cylindrical, many flowered. Spadix of numerous green flowers on a peduncle, thick and enlayed upwards. Grows in rivers and lakes in Canada, New York and New England.

9. The Potomogaton olrutus. Stem, round, simple and slender. Leaves, linear, lanceolate, sessile, rather acute; spikes, long, pedunculate, dense. Vermont to Georgia.

10. The Potomogaton prolongus. Leaves, oblong, ovate, obtuse, many veined. Flowers in July and August. *

11. The Potomogaton perfoliatus. A common species in ponds and slow waters. Leaves, cordate, clasping the stem. Flowers, purple, alternate. Flowers in July.

12. The Potomogaton pauciflorus. Stem, dichotomus, filliform. Leaves, linear, alternate, sessile. Flowers, three to five, greenish. Very delicate plant.

13. The Potomogaton pusillus. Stem, filliform, branched. Leaves, linear, subulate, membraneous, very acute, sessile. Few flowered. Shallow ponds.

14. The Potomogaton pectinatus. Stem, slender, branched, striate. Leaves, numerous, long, very linear. Plant, bushy and very leafy. New England to Wisconsin.

15. The Potomogaton Robbinsii. Stem, long, branched. Leaves, lanceolate, linear ; spikes, oblong, small and few flowered; pedicels shorter than the leaves. New Hampshire west to Ohio.

Of the Callitriche or Starworts, we have two species suitable to the Aquarium.

1. The Callitriche verna. Broad Leaved Starwort or Water Star. The name of this plant is derived from the Greek, 
signifying "beautiful hair." It is a small plant with a filliform stem, with small lanceolate leaves, spatulate and obvate, forming star like tufts on the surface of the water. Flowers from May to August.

2. Callitriche linearis, Narrow Leaved Starwort. This plant possesses the general character of the verna, only the leaves are more linear.

The Threadfoot, Podostemum ceratophyllum, grows in streams on rocks and stones; very plentiful in New Jersey. Stem filliform, leaves pinnate floating on the surface of the water. Flowers in July.

The Schollera graminea, Water Star Grass. This is a slender plant, with a stem six or eight inches long, leaves sessile, extremely linear resembling grass. Grows in sluggish streams. Flowers, bright yellow. Spathe one or two flowered. Flowers in July.

The Isoetus lacustris, Quillwort. This is a crytogammanous plant growing in ponds and sluggish streams. It derives its name from the Greek, meaning "equal year," because it is alike the whole year. Leaves numerous, radical, tufted, simple, somewhat spreading, containing numerous cells divided by lateral and transverse divisions.

The Azolla caroliniana. This plant belongs also to the Crytogammia. Grows in ponds and swamps and distributed from New York west to Illinois. Leaves oblong, ovate, fleshy and floating, very small and reddish beneath.

The Ilottonia inflata, or Water Feather. This is one of the most beautiful plants found in our ponds, and I find it is extremely local, but where it is found it abounds in considerable quantities. I have placed these plants in tanks when only an inch in height and in three or four weeks they grew 
fifteen to eighteen inches, the beautiful flowers then expanded, retained their beauty for several weeks, then drooped, the plants then wasted as it were away, sloughing off as they do in their native waters. I have tried this very many times, but have never succeeded in keeping them through the winter. They are well worthy a place in the Aquarium however, as their comparatively short existence is amply made up by their beauty; they should be immediately taken out at the first sign of decay. This beautiful aquatic has the leaves in whorls on the upper part of the stem only, the lower portion being naked. The leaves are fine like feathers, the flower stalks are arranged umbel like, swollen very much betwixt the joints and hollow within. The foliage is very bright light green. Flowers pinkish white, small but numerous. Flowers in August and September. Its geographical range extends from Massachusetts south to Florida and southwest to Louisiana.

The next aquatic plants worthy of notice are the Family of Ranunculace or Crowfoot, of these we have three species suited to the Aquarium; characterized and distinguished as follows :

1. The Ranunculus aquatilis, Water Crowfoot. This species has the stem almost entirely submerged, creeping on the soil and sending out numerous filliform, dissected leaves at the joints, the floral stalks projecting from four to six inches above the water's surface, bearing at their extremities peltated three parted leaves, and conspicuous bright yellow flowers. Flowers in June. Generally distributed throughout the Atlantic States in ponds and deep holes in swamps.

2. The Ranunculus fluviatilis, River Crowfoot. Stem, slender, about a foot high, with filliform leaflets at the joints, and 
bears its small white flowers on the surface of the water. Grows in rumning streams. Flowers in July. This is a beautiful species easily distinguished.

3. The Ranunculus multifidus, Water Buttercups. This species is closely allied to the aquatilis, but is readily distinguished from the latter, by the fact, that it never bears any leaves on that portion of the floral stalk which projects above the surface of the water. Flowers similar to the aquatitis, large, yellow and bright.

Of the ten species of Lobelias found in the United States, but one of them is suitable to the Aquarium. The Lobelia dortmanna or Water Lobelia. This curious aquatic is well adapted to the tank, as it is an entirely submerged species, the flowers alone rising above the water. The stem is erect, hollow and long, rising above the water's surface, and bearing a raceme of three or four remote pedicellate flowers of a pale blue color. Flowers in July. Leaves, radical, erect and recurved at the tip. Grows in ponds, and is distributed from New York south to Georgia.

Of the Brooklime we have two species:

1. The Veronica americana, American Brooklime. Stem, glabrous, decumbent at its base, and rooting; fleshy, very smooth, erect above. Leaves ovate, acute, serrate, abrupt at the base. Racemes opposite, loose, longer than the leaves. Pedicels twice as long as the bracts. Flowers, blue or purplish blue. Flowers in June and July. This plant is generally distributed in brooks and clear waters throughout the United States and Canada.

2. The Veronica anagallis, Water Speedwell. This plant grows in similar localities to the americana, and bears purple flowers. 
The Cardamine lirsuta. Common Water Cress. This is a very ornamental plant for the Aquarium. Stem about a foot high; obtuse ovate leaves, radical, placed alternate; flowers small and white, projecting above the waters' surface. Flowers in June. A common species growing in clear running waters and very generally distributed. The verdure of this plant is very bright green.

Of the Sagittarias or Arrowheads we have three species suitable for large tanks. They have large bulbous roots and require considerable soil.

1. The Sagittaria saggittifolia, Common Arrowhead. Stem usually two feet high, projecting out of the water; leaves long, straight, acute and lanceolate. Flowers, white. Blossoms in July. Grows in ponds and swamps, and is generally distributed.

2. The Sagittaria heterophylla. This species is about half the size of the former, and a much more slender plant. Leaves linear, lanceolate and narrow lobed. Flowers, few. Blossoms in July. Found in ponds and ditches, and is generally distributed.

3. The Sagittaria acutifolia, Acute Arrowhead. This is the smallest of the Genus, seldom exceeding six or eight inches in height, with subulate acute leaves, convex on the back and sheathing at the base, bearing its flowers, which are few, on pedicels. Grows in swamps. Flowers in July. Very common.

The next to notice are the Pontedeiras, two species of which belong to our flora :

1. The Pontedeiras cordata. Pickerel Weed. This is a large plant attaining a height of two feet, stem thick, having 
oblong cordate leaves rising from the base. Flowers, bright blue, sessile, collected into twos and threes on a long dense spike.

2. The Pontedeira angustifolia. Narrow Leafed Pickerel Weed. This plant resembles considerably the preceding species, differing from it however in having much narrower leaves. Both of these plants are only suitable to very large tanks.

Of the true Water Lillies we have three species, but all of them are too large for general purposes.

1. The Nymplia odorata. The White Lily. This plant bears the most beautiful flower of any of our aquatics, and is very fragrant. Found in ponds and lakes. Common. Flowers pure white.

2. The Nuphar advena. Yellow Water Lily. Grows usually in company with the odorata. Flowers bright yellow.

3. The Nuphar lutea. Small flowered Pond Lily.

Of the Sparganiums we have five species. The name is derived from the Greek, meaning "ribbon like leaves."

1. The Sparganium angustifolium. Having long narrow leaves floating on the surface of the water. Grows in ponds and swamps.

2. The Sparganium americanum. Similar to the above, and having a simple stem.

The other three species are the ramosum, simplex and natans, these burr reeds are not of much value to the Aquarist, being too large for ordinary purposes.

Of the Arams we have two:

1. The Calla palustris. Water Aram. This singular and beautiful plant found in clear waters, is furnished with footstalks rising to the surface of the same, bearing masses of white flowers: 
2. The Orontium aquaticum. Golden Club or Floating Aram. This plant is not of much value to the Aquarium, but being a true aquatic, I introduce it here. The scape or stem is long and cylindrical, with large radical, lanceolate, ovate leaves; flowers, yellow, dense and exuding a disagreeable odor. Flowers early in the season, usually in May.

The Glyceria fluitans. Floating Fescue. This is also a large plant, with long linear leaves, which rise and float on the surface of the water; grows in ponds and swamps.

The Acorns calamus. Calamus or Sweet Flag. A plentiful species growing in ponds and swamps. This plant is large, with long linear leaves, lanceolate, and shaped like a sword. Its root is dried and used for medicinal purposes. Can only be used in a very large tank.

The Najas canadensis. Water Nymph. A very good plant for the Aquarium, having a flexible slender stem, erect, always submerged, with filliform or threadlike leaves. Flowers with stamens, with the perianth wanting. Grows in stagnant waters.

Of the Charas we have two species:

1. The Chara flexilis. Flexible Chara. An excellent ærator for the Aquarium, indeed none are better. It is also extremely free of growth and always completely submerged. The stems are jointed and form a net-like appearance. Before the late American Museum building was destroyed by fire, we had a tank completely filled with this plant alone, that presented a beautiful appearance, having been growing therein several years; the whole interior of the same was a dense mass of fine network, the water always remaining clear and sparkling, sustaining a numerous family of Sticklebacks, Tessellated Darters and Tritons. To those who fancy this plant, it is sufficient to purify the water of their Aquarium, 
and a little placed therein at the proper season soon spreads and increases, filling the whole of the same with its bright green verdure. It is easily thinned out as taste may dictate.

2. The Chara vulgaris. . Feather Beds. This also is a beautiful plant, of the same general character. as the flexilis, but is more brittle, requiring very careful handling. The stem is slender with whorls of eight filliform leaves, at short distances apart, having the appearance of a tuft of feathers, hence its name. Grows in still ponds, in masses at the bottom. The green color of this species is lighter than the flexilis.

The Hydropeltis purpurea. Water Shield. A very curious and interesting plant, having long foot stalks bearing fine, flat, elliptical leaves, floating on the surface of the water, and attached to the stem by the centre of the under part of the leaf, thus forming a shield. The leaves are smooth, shining dark green on their upper side, and woolly on the under. Whole plant covered with a gelatinous substance. The flowers are borne on long foot stalks, springing from the side of the leaf stalks. Flowers, purple, and blooms in July. Grows in ponds and lakes, usually with the Nymphas and Nuphars.

The Isnardia palustria. Water Purslane. Stem, prostrate; creeping at the bottom of ponds, with opposite leaves, ovate and lanceolate. Bearing single axillary flowers, without corolla. Flowers in June.

The Hydrodicton urticulatum. This is a beautiful plant, of a bright light green color, resembling delicate lace work; it is free of growth, but its extremely fragile character renders it easily destroyed by the fish.

Of the Rushes, we have two, but although truly aquatic are not of much value for our purpose. 
1. The Juncus effusus. Common Rush. Bears tufts of long awl-shaped leaves, and stems like the spines of a porcupine, bearing flowers in loose lateral panicles. This is the plant used in making mats.

2. The Juncus scirpus. Club Rush. Very common in marshy localities, bearing flowers in little solid, oval spikelets.

Next are the Lemnas, or Duck Meats. The name Lemna taken from "lepis," a scale, which it resembles in form. Its common name suggested from the fact that wild ducks are particularly fond of it, eating it with avidity. Of these interesting and useful plants for the Aquarium, we have five species suitable to it. The Lemnas are all surface plants, never attached to the soil, always floating, and from their under side send down one or more small, fibrous, thread-like roots, through which they receive nourishment from the water. They are all annuals, but will last in the tank indefinitely, and affords an excellent screen for the water, if your tank is exposed to too much light. The species are all readily distinguished by the following characteristics.

1. The Lemna minor. Little Lemna. This may be identified by its small, entire, scale-like, light green leaves, sending down but one single fibrous root. Grows in ponds.

2. The Lemna gibba, distinguished by its pellucid character. Grows in ponds.

3. The Lemna polyrhiza. Water Flax Seed. Its division of leaves being more firmly united, and sending down from eight to twelve black fibrous roots. This plant is very abundant, growing in ponds, intermixed with the Lemna minor.

4. The Lemna perpusilla. The Least Lemna. This is a very minute species, its exceeding small size being its chief feature of distinction. 
5. The Lemna trisulca. Ivy Leaved Lemna. This plant is very distinctly characterized. The leaves are of a much darker shade of green than the before mentioned species. Its mode of propogation is peculiar. The leaves are nearly onehalf an inch in length, thin and pellucid, divided into three lobes, with a single fibrous root attached. A flattened stem emerges from the point of each lobe, which in a few days expands into another leaf; when this leaf becomes fully developed, other stems emerge from the lobes of the same, that in time form other leaves; this process continues indefinitely throughout the vernal season, until large masses are formed, all the leaves being united in this manner. If a few leaves only of any of the Lemnas are placed, during the spring or summer, in the Aquarium, they will increase rapidly and soon cover the surface of the water. This plant is usually found in sluggish waters, sometimes in ponds.

The Riccia natans is another floating plant of a bright green color, common in sluggish streams, growing intermixed with the Lemnas and Hydrodicton. Grows prolificly in the tank.

The Fontanalis gigantea is a handsome plant, growing in clear waters, liberating oxygen freely. Stem profusely branched, especially above, color of the foliage, very dark green. Leaves, oblong, ovate, acute. A very local species.

The Tetraspora ulvacea. This plant grows in swamps and ponds and bears.an affinital resemblance to the marine Ulra latissima.

The Cladophera glomerata. This a fiesh water Algo, growing on rocks and stones in running brooks.

The Drapernaldias, Tyndarideas, Conferva, Bratches permea and Cladophera are all fresh water Algw, too fine in texture for general purposes. 


\section{GLOSSARY OF TECHNICAL TERMS USED.}

Acutifolia, the leaf acutely pointed.

Aculeatus, prickly, with spines.

Abbreviated, short.

Anas, the vent.

Anal fin, the lower posterior fin of a fish.

Anterior, before.

Ambiguous, of varied or undecided character.

Amphibious, living both on land and water.

Albidus, white.

Annual, yearly, lasting but a year.

Animalcule, microscopic aquatic life.

Attenuated, becoming thin and slender.

Atronasus, black-nosed.

Aqua, water.

Aquatic, pertaining to water.

Astacus, a lobster.

Auratus, golden.

$A x i l$, the angle beneath a leaf.

Appendix, furnished with an appendage.

Axillary, belonging to or growing on the axil.

Argenteus, silvery.

Augustifolia, narrow leaved.

Auriculata, with ear-shaped appendages.

Biflora, two flowered.

Bilineata, two striped.

Bison, a buffalo.

Botany, the science or study of plants.

Bipartita, divided into two parts to the base.

Biaculeatus, two spined.

Confinis, border, or edge.

Carnivorous animal or flesh eaters.

Carpel, simple pistil, or a part of a compound one.
Capillary, hair-like.

Caducous, falling off at the period of expansion.

Convex, bulging out in a rounded form.

Concave, the opposite to convex.

Cornutus, horned.

Cephalus, pertaining to the head.

Coleoptera, a class of insects having wing cases.

Cordata, heart shaped.

Crenate, having the margin even notched or scolloped.

Crytogammia, flowerless plants.

Clandestina, hidden, concealed.

Corolla, the inner of the two flower envelopes.

Calyx, the outer covering of a flower.

Dentate, toothed.

Decumbent, reclined on the ground.

Diaphanous, transparent.

Dorsal, upper part of the back of a fish.

Dorscl Line, a line extending along the dorsal.

Dorsal fin, the fin situated on the dorsal. Dichotomously, forking into two branches.

Entomology, the science or study of insects.

Filliform, thread-like.

Fibullous, bearing fibre-like hairs.

Filamantose, composed of threads or filaments.

Furcate, forked.

Fluitans, floating.

Fluvial, relating to fresh water.

Fusilform, spindle shaped.

Fugacious, falling off, peris ing soon.

Gibbous, protuberant swelling. 
Granulated, roughed in lines.

Guttatus, sprinkled in drops.

Glaber, or glabrous, smooth.

Glommerala, growing in a massive form.

Graminea, grass-like.

Graci'is, slender formed.

Grisea, gray.

Gregarious, going in numbers together.

IHydrophitus, a genus of Coleoptera, the name signifying "I love the water."

Hirsuta, hairy.

Hiterophyllum, having the leaves varied from the usual form.

Involucrate, having a set of bracts surrounding a flower cluster.

Infloresence, flowering part of a plant.

Intermedia, between.

Intrepidus, bold, fearless.

Ichthyology, the science or study of fishes.

Inflata, inflated, swollen.

Irides, the part of the eye encircling the pupil.

Isætus, equal year.

Lamelliform, composed of flat plates.

Longiiauda, long tailed.

Lanceolate, lance shaped.

Lacustris, pertaining to lakes and swamps.

Lepis, a scale.

Maxilingua, large tongued.

Macrocephala, large headed.

Maculata, spotted.

Millepunctatus, many spotted.

Multifasciata, many barred.

Multilineatus, many lined.

Multifid, many cleft.

Natans, floating.

Nebulosa, clouded.

Niger, black.

Nigricans, black.

Notata: ten spotted.

obcordate, inverted, heart-shaped.

Ovate, egg shaped, with the lower extremity broadest.

Opercles, gill covers.

Odorata, a sweet scented plant.

Obscurus, obscure.

Occidentalis, western.

$$
\mathrm{M}^{*}
$$

Ornata, ornamented:

Ocellated, with eye-like spots.

Pallidus, pale.

Palate, the convex base of the lower lip of the corolla.

Panicles, in which the flowers are arranged on distinct branching stalks round a lengthened axis.

Perennial, perpetual.

Pedicels, the stalk of a particular flower.

Pedicellate, having a pedicel.

Pellate, shield-shaped, the stalk being attached to the centre of the leaf.

Pectoral fins, the fins on the body near the gills.

Pedunculated, having a flower stalk.

Pectinated, comb-like.

Picta, painted.

Pinnatifed, cleft in many parts, divided almost to the axis into lateral segments.

Petiole, the foot stalk of a leaf connecting the blade with the stem.

Pupil, the sight of the eye.

Puncaled, spotted.

Pygmæus, pigmy, little.

Pellucid, perfectly clear and transparent.

Pistil, the female sexual organ of all phaxnogamous plants.

Phænogamous, flowering.

Prinate, divided into leaflets.

Perianth, the calyx that envelopes a single flower and is immediately contiguous to it.

Quadrate, square.

Quinate, in fives.

Quadrimaculata, four spotted.

Quiescens, rest, repose.

Radical, proceeding immediately from the root.

Ramose, bearing branches.

Ramulose, bearing many branchlets.

Reniform, kidney shaped.

Resupinata, inverted in position, by the twisting of the stalk.

Raceme, an indefinite infloresence with single pedicelled flowers arranged along a lengthened axis.

Reticulated, netted. 
Rosulate, like a rosette.

Rhizome, root stock or stalk.

Rostrata, beaked.

Stamen, the male organ of plants.

Sextagonal, six sided.

Setacious, bristle like.

Sessite, dwarfish, sitting, not stalked.

Scuta, shield shaped.

Syadix, a kind of fleshy spike.

Spiralis, spiral.

Serrated, notched on the edge.

spikelet, a small spike forming part of a large one.

Sinciput albida, having the forehead white.

Subluate, awl-shaped, linear, very narrow,

* tapering gradually to a fine point from a broad base.

Scape, a radical stem bearing the inflorescence, without leaves.

Sparyanium, a plant having ribbon-like leaves.

Subrevolute, rolled slightly backwards.
Subtrilobate, slightly three lobed.

Spatulate, shaped like a druggist's spatula, or like a battledore.

Stolons, a rooting branch.

Spathe, the encircling bract of a spadix.

Striated, striped.

Trilobate, three lobed.

Tesselated, checkered.

Translucent, clear and shining.

$U m b e l$, the pedicels all proceeding from a single point and of equal length.

Unicolor, one colored.

Utricula, a little bottle.

Versicolor, variegated in color.

Ventrals, the small fins anterior to the anal fin.

Vericills, whorls.

Verticillate, whorled.

Vulgaris, common.

Vivarium, animal life.

Verticillatum, from verticillus, a little whorl. 


\section{GENERAI INDEX.}

\begin{tabular}{|c|c|}
\hline 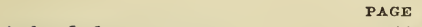 & \\
\hline Aphredoderus sayanus,..$\ldots \ldots \ldots \ldots .44$ & Bryttus unicolor,............ \\
\hline Abramis versicolor, $\ldots \ldots \ldots \ldots \ldots \ldots 4$ & Blind Fish of Kentucky,,$\ldots \ldots \ldots \ldots 93$ \\
\hline American Yellow Perch,........... s9 & Black or Dusky Triton,............105 \\
\hline rrangement of the Aquarium,..... 25 & Bull Frog,,...$\ldots \ldots \ldots \ldots \ldots$ \\
\hline nguilla tenuerostris,........... $7 \mathrm{~s}$ & Brooklime,.$\ldots \ldots \ldots \ldots \ldots \ldots \ldots \ldots$. 129 \\
\hline Amblyopsis spelius............... 93 & Burr Reeds,............... . \\
\hline Arams,,$\ldots \ldots \ldots \ldots \ldots \ldots \ldots \ldots \ldots \ldots \ldots \ldots$ & Bratches permea,................ \\
\hline Arrowheads,....................130 & olden................ \\
\hline Amia occidentalis, .............. 98 & auratus,............ \\
\hline lva,$\ldots \ldots \ldots \ldots \ldots \ldots \ldots . . \ldots 8$ & Pickering,............ \\
\hline fish,,$\ldots \ldots \ldots \ldots \ldots \ldots \ldots \ldots . \ldots 8$ & Common Sun Fish, ,............ \\
\hline rostrata,.............. 98 & as pallidus,,$\ldots \ldots \ldots \ldots \ldots$. 70 \\
\hline ephala,............98 & tuberculatus,........ \\
\hline or $, \ldots \ldots \ldots, \ldots \ldots 78$ & d Lamprey,.......... \\
\hline bicolor,$\ldots \ldots \ldots \ldots \ldots$....... 98 & brilliant........... \\
\hline ................... 99 & elegant............. \\
\hline ..............108 & bbous........... \\
\hline sh,.............108 & ck................. \\
\hline adensis, . . ...........123 & vn............. \\
\hline$\ldots \ldots \ldots \ldots \ldots \ldots 34$ & $\operatorname{mon} . . . \ldots \ldots \ldots \ldots . \ldots 77$ \\
\hline$e, \ldots \ldots \ldots \ldots \ldots \ldots, 37$ & æneus, $. . \ldots \ldots \ldots \ldots 45,67$ \\
\hline$\ldots \ldots \ldots \ldots \ldots \ldots \ldots 43$ & fasciatus,,..$\ldots \ldots$ \\
\hline$\ldots \ldots \ldots \ldots \ldots \ldots .45$ & urus,,$\ldots \ldots \ldots \ldots$ \\
\hline ish,$\ldots \ldots \ldots \ldots \ldots$. 48 & tacanthus, ........ \\
\hline ace,$\ldots \ldots \ldots \ldots \ldots \ldots 56$ & hus hexacanthus, ....... \\
\hline,$\ldots \ldots \ldots \ldots \ldots \ldots \ldots 59$ & chus sparvides,.......... \\
\hline Black Headed Dace,.............. 60 & us irideus,............ \\
\hline$\ldots \ldots \ldots \ldots \ldots \ldots 66$ & hus gulosus,........ \\
\hline essellatum, ...........67 & Centrarchus virides, ........... \\
\hline$\ldots \ldots \ldots \ldots \ldots \ldots 87$ & Corvina oscula,............... 91 \\
\hline & Corvina Richardsonii, $\ldots \ldots \ldots \ldots \ldots . . .91$ \\
\hline Bryttus punctatus, ................. 91 & Corvina grisea, $. . \ldots \ldots \ldots \ldots \ldots \ldots . . .61$ \\
\hline Bryttus reticulatus,............... 91 & Cat Fish, Blue................. \\
\hline
\end{tabular}


PAGE

Cat Fish, Yellow................. 92

Cat Fish, Channel................ 92

Cat Fish, Mud................... 92

Cat Fish, Small Black Bull Head..... 92

Cat Fish, Young................. 92

Cyprinus carpio,................. 93

Common Carp,$\ldots \ldots \ldots \ldots \ldots \ldots \ldots . . .63$

Chubsucker, Long Finned.......... 94

Chubsucker, Round Back........... 94

Catastomus communis,........... 94

Catastomus oneida,............... 94

Catastomus aureolus, ............. 94

Catastomus nigricans, ............ 94

Catastomus macrolepidotus, ........94

Catastomus longirostris,,$\ldots \ldots \ldots \ldots . . .94$

Catastomus maculosus,............ 94

Catastomus elongatus,............ 94

Catastomus vittatus, ............. 94

Catastomus duquesnii,............ 94

Catastomus sucellata,............. 94

Catastomus maxilingua,........... 94

Corregonus albus, $\ldots \ldots \ldots \ldots \ldots \ldots \ldots .67$

Corregonus clupeiformis,.......... 97

Corregonus otsego,.............. 97

Corregonus harengus, ............ 97

Clupidæ,....................... 98

Cyclostomi,..................... 98

Chrysemys picta,................. 99

Ceratophyllum demersum,..........120

Callitriche verna,..................126

Callitriche linearis,...............127

Cardamene hirsuta,...............130

Calamus,.........................132

Calla palustris,$\ldots \ldots \ldots . . . \ldots . . . . . .131$

Chara flexilis,...................132

Chara vulgaris,..................133

Common Rush,..................134

Club Rush,......................134

Confervæ,........................135

Cladophera glomerata,............135

Dace, Pigmy................... 54

Dace, Black Nosed............... 56

Dace, Shining.................... 5s

Dace, Banded................... 59

Dace, Black Headed.............. 60

Dace, Horned..................... 62

Dace, Golden................... 65

Drapernaldia, ..................135
PAGE

Esox reticulatus, $\ldots \ldots \ldots \ldots \ldots \ldots \ldots 35$

Esox fasciatus, ................ 36

Eel, Common.................... 78

Eel, Plain Mud Lamprey........... 78

Eel, Small Lamprey............... 79

Esox estor,.................... 96

Esox tradecem radiatus,........... 96

Esox phaleratus,................ 96

Eel, Beaked..................... 98

Eel, Bull Head................... . 98

Emys punctata,.................102

Fundulus veridescens,............ st

Fundulus zebra,.................. 87

Fundulus fasciatus,.............. 87

Floating Fescue,.................132

Floating aram, ................. 132

Fontanalis gigantea,............135

Golden Carp, ................. 31

Gold Fish, $\ldots \ldots \ldots \ldots \ldots \ldots \ldots \ldots \ldots . \ldots . \ldots 1$

Gasterosteus biaculeatus, .......... 81

Gasterosteus neoboracensis,....... 83

Gasterosteus occidentalis, ........ 84

Gasterosteus quadracus,............ 85

Gasterosteus concinnus, .......... 91

Gasterosteus mainensis, $\ldots \ldots \ldots \ldots . . .91$

Gasterosteus niger,.............. 91

Glyceria fluitans, $\ldots \ldots \ldots \ldots \ldots \ldots \ldots . . .132$

Glossary,......................136

Huron nigricans, $\ldots \ldots \ldots \ldots \ldots \ldots$. s9

Hydrargira diaphana,............. 86

Hydrargira atricada,............. 96

Hydrargira ornata,................ 96

Hydrargira nigrofasciata,.......... 96

Hydrargira multifasciata,.......... 96

Hydropholis triangularis,...........113

Hydropholis glaber, ...............114

Hydropholis ovalis,.............. 114

Hydropholis lateralis,..............115

Hottonia inflata,................127

Hydrodicton utriculatum,............133

Hydropeltis purpurea, ............133

Isnardia palustris,...............133

Isoetus lacustris, ...............127

Juncus effusus,...................134

Juncus scirpus,..................134

Killifish; Big.................... 87

Killifish, Barred................ 87

Killifish, Striped ............... 87 
PAGE

Lepisosteus Bison, .............. 37

Labrax pallidus, ................ 42

Labrax nig: cans,.............. 43

Labrax albidus,................ 89

Labrax notatus,............... 89

Labrax multilineatus,............ 89

Leuciscus pygmæus,............ 54

Leuciscus atronasus, ............ 56

Leuciscus nitidus,............. 5s

Leuciscus vittatus, ............ 59

Leuciscus atromaculatus, .........60 60

Leuciscus hudsonius,............. 61

Leuciscus cornutus,.............. 62

Leuciscus pulchellus,............. 95

Leuciscus argenteus, ............. 95

Leuciscus corporalis,............ 85

Leuciscus elongatus,............. 95

Leuciscus dissimilis,............. 95

Leuciscus biguttatus,............ 95

Leuciscus cephalus,............. 95

Lebias ovinus, ................ 68

Lebias ellipsoides,............... 95

Labeo oblongus,................ 72

Labeo elegans, ................ 73

Labeo gibbosus, . .............. 74

Labeo cyprinus,................. 93

Labeo esopus,.................. 94

Leucioperca americana,........... 89

Leucioperca grisea,............... 89

Leucioperca canadensis,.......... . 89

Lake Sheepshead,.............. 91

Lepisosteus platyrhincus, .......... 98

Lepisosteus longirostris,.......... 98

Lobelia Dortmanna,..............129

Lily, White....................131

Lily, Yellow Water...............131

Lily, Small Flowered Pond,.........131

Lemna minor, .................134

Lemna gibba,....................134

Lemna polyrhiza,................134

Lemna perpusilla,...............134

Lemna trisulca,.................135

Minnow, Träsparent............. 83

Minnow, Champlain.............. 87

Minnow, Ornamented............. 96

Minnow, Black Striped,........... 96

Minnow, Many Barred,............ 96

Millfoil, Floating.................121
Millfoil, Water.................120

Millfoil, Spiked Water,............121

Molinesia latipennis, ............ 96

Mud Fish, Western.............. \&s

Mud Lamprey, Colored............. 98

Many Spotted Triton,..............103

Myriophyllum verticillatum,........120

Myriophyllum spicatum,...........121

Myriophyllum heterophyllum,.......121

Myriophyllum scabatrum,...........121

Myriophyllum ambiguum,..........121

Myriophyllum tenellum,...........122

Nympha odorata,................131

Nuphar advena,..................131

Nuphar lutea,...................131

Najas canadensis,...................132

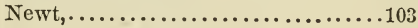

Orontium aquaticum, .............132

Pickerel, Common............... 35

Pickerel, Varied.................. 36

Pimeoma sub-fasciatum............. 38

Pickering, Champlain............. 38

Perca flavescens, ............... 39

Perca granulata,................. 88

Perca acuta,................... 88

Perca gracilis,.................. 88

Perca nebulosa,................ 88

Perca minima,................. 88

Perca serrata-granulata,.......... 41

Perch, American Yellow........... 39

Perch, Rough Yellow............. 41

Perch, White.................. 42

Perch, Spineless.................. 44

Perch, Rough Headed Yellow,....... 88

Perch, Sharp Nosed Yellow,........ 88

Perch, Slender Yellow,............. 88

Pomotis vulgaris,................ 46

Pomotis appendix, .............. 48

Pomotis secludens,.............. 50

Pomotis ravaneli,............... 90

Pomotis holbrooki,.............. 90

Pomotis incisor, ............... 90

Pomotis gibbosus,.............. 90

Pomotis solis,................. 90

Pomotis catesbei, ............... 90

Pigmy Dace, ................... 54

Pigmy Trout,...................66

Pimelodus atrarius,............. 75 


\begin{tabular}{|c|c|}
\hline PAGE & \\
\hline Pimelodus pullus,,.$\ldots \ldots \ldots \ldots \ldots \ldots$ & Ranunculus aquatilis, .............128 \\
\hline Pimelodus catus,................ 77 & Ranunculus fluviatilis,............128 \\
\hline Peteromyzon appendix,........... 79 & Ranunculus multifidus, ............129 \\
\hline Peteromyzon argenteus, $. . \ldots \ldots \ldots . . .8$ & Rush, Common..................134 \\
\hline Pickerel Weed,..................130 & Rush, Club................... \\
\hline Pickerel Weed, Narrow Leaved,......131 & Riccia natans,.$\ldots \ldots \ldots \ldots \ldots \ldots$ \\
\hline Painted Water Turtle,............. 99 & Rana pipiens,,$\ldots \ldots \ldots \ldots \ldots \ldots \ldots \ldots . \ldots 109$ \\
\hline Pike Perch, Yellow,............. 89 & Rana fontanalis,.................110 \\
\hline Pike Perch, Gray,................ 89 & Salmo fontanalis,,$\ldots \ldots \ldots \ldots \ldots \ldots . \ldots 34$ \\
\hline Pike Perch, Canada,.............. 89 & Salmo erythrogaster, $. . \ldots \ldots \ldots \ldots . . . .97$ \\
\hline Pimelodus nigricans, ............. 92 & Salmo confinis, $\ldots \ldots \ldots \ldots \ldots \ldots \ldots . . .67$ \\
\hline ænosus, .............. 92 & Salmo amethystus,............... 97 \\
\hline lbidus,,$\ldots \ldots \ldots \ldots \ldots . . . .62$ & Salmo salar,...$\ldots \ldots \ldots \ldots$ \\
\hline niscatus,........... 92 & adensis, $. \ldots \ldots \ldots \ldots \ldots . . \ldots 7$ \\
\hline $1 \mathrm{~s}, \ldots \ldots \ldots \ldots \ldots . .62$ & Shiner,................ \\
\hline tus, $\ldots \ldots \ldots \ldots .92$ & n Eater,..$\ldots \ldots \ldots \ldots \ldots$ \\
\hline ................ 92 & soleucas,................ 65 \\
\hline cens, ............. 92 & d Lebias, .............. 68 \\
\hline,$\ldots \ldots \ldots \ldots \ldots 92$ & tle................ 69 \\
\hline ............... 92 & n................... 70 \\
\hline$s, \ldots \ldots \ldots \ldots \ldots, 92$ & ned.................... 71 \\
\hline halus,,$\ldots \ldots \ldots .62$ & on................. 94 \\
\hline$\ldots \ldots \ldots \ldots \ldots \ldots, 92$ & a........... \\
\hline,$\ldots \ldots \ldots \ldots \ldots \ldots \ldots \ldots \ldots 112$ & t..$\cdots \cdots \cdots \cdots \cdots$ \\
\hline$u s, \ldots \ldots \ldots \ldots \ldots 112$ & ... 94 \\
\hline,$\ldots \ldots \ldots \ldots \ldots \ldots 112$ & Scaled............. \\
\hline,$\ldots \ldots \ldots \ldots \ldots 113$ & A.................. 94 \\
\hline sum, $\ldots \ldots \ldots \ldots 124$ & sed................ 94 \\
\hline nani,...........125 & ri.................. 94 \\
\hline ..............125 & 1....................994 \\
\hline hyllus, .........125 & ................... 94 \\
\hline olium,,$\ldots \ldots \ldots 125$ & ................... 94 \\
\hline , $\ldots \ldots \ldots \ldots \ldots \ldots$ & vo Spined ........... s1 \\
\hline ….........125 & w York............. 83 \\
\hline$\ldots \ldots \ldots \ldots \ldots 125$ & or Many Spined.... 84 \\
\hline $\mathrm{s}, \ldots \ldots \ldots \ldots \ldots . .125$ & ar Spined............ 85 \\
\hline gus,............125 & Turtle ...............102 \\
\hline $\operatorname{tus}, \ldots \ldots \ldots \ldots 125$ & . $\ldots \ldots \ldots \ldots \ldots \ldots \ldots 91$ \\
\hline us,............. & \\
\hline$\cdots \ldots \ldots \ldots \cdots 1$ & \\
\hline tus,,$\ldots \ldots \ldots \ldots .125$ & metrica,............106 \\
\hline nsii,............125 & a erythronata,.............106 \\
\hline , $\ldots \ldots \ldots \ldots \ldots \ldots \ldots$ & a picta,.................107 \\
\hline folia, ............131 & ubviolacea,...........107 \\
\hline ..............133 & igera,..............107 \\
\hline & ciput albida,..........107 \\
\hline & andra gutta lineata,..........107 \\
\hline 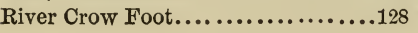 & Salamandra auriculata,.............107 \\
\hline
\end{tabular}




\begin{tabular}{|c|c|}
\hline Salamandra talpoidea,.............107 & \\
\hline Salamandra quadrimaculata,.. $\ldots . .107$ & 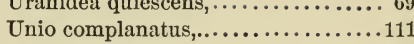 \\
\hline alamandra haldemani,...........107 & Utricularia inflata,.............. \\
\hline Salamandra glutinosa,............107 & Utricularia purpurea,........... \\
\hline Salamandra coccinea,..............107 & Utricularia intermedia,.......... \\
\hline Salamandra bilineata,.............107 & Utricularia Robbinsii,......... . \\
\hline Salamandra granulata,.............107 & Utricularia striata,..............11 \\
\hline Salamandra longicauda,...........107 & Utricularia longirostris,...........11 \\
\hline Salamandra fasciata,........... & Utricularia biflora,............... \\
\hline Salamandra salmonea, ......... & bipartita,.............. \\
\hline Spring Frog,,$\ldots \ldots \ldots \ldots \ldots \ldots$ & Utricularia clandestina,.. .........11 \\
\hline Starwort, Broad Leaved.............126 & Utricularia gibba,.................11 \\
\hline vort, Narrow Leaved...........127 & Utricularia minor,.$\ldots \ldots \ldots \ldots \ldots \ldots$ \\
\hline Schollera graminea,............ & 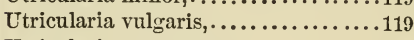 \\
\hline Speedwell, water............. & Utricularia resupinata,.............11 \\
\hline lia,..............129 & Utricularia cornuta,..............12 \\
\hline aylla,.............130 & Utricularia subulata, .............11 \\
\hline lia,.............130 & Variegated Bream, .............. \\
\hline nium angustifolium,.........131 & ralis, ..............124 \\
\hline Sparganium americanum,...........131 & Veronica americana,...............129 \\
\hline $\operatorname{lag}, \ldots \ldots \ldots \ldots . . . . . \ldots \ldots \ldots . . .132$ & rallis, ...............129 \\
\hline .............. & Flaxseed, ......................... \\
\hline Darter,............. & Purslane,,$. . . \ldots \ldots \ldots \ldots \ldots . . . . . .13$ \\
\hline ainted Water.............. 99 & Water Shield,.. ..................13 \\
\hline ater............ 102 & Aram,...................132 \\
\hline millepunctatus,............103 & Water Nymph, ..................132 \\
\hline grinus.............. & Water Lily,......................131 \\
\hline Triton, niger. $\quad$.............. & Water Lobelia, ....................129 \\
\hline , porphyriticus,.......... & Water Speedwell,................129 \\
\hline Triton, ingens................ & Water Cress, ....................130 \\
\hline Triton, Jeffersoni............. & Water Bnttercups,................129 \\
\hline Tyndarideas, & Water Crowfoot,..................128 \\
\hline Threadfoo & Water Star Grass, .................12 \\
\hline & Water Thyme, ..................12 \\
\hline iglidæ, $\ldots \ldots \ldots \ldots \ldots \ldots \ldots \ldots \ldots \ldots \ldots \ldots \ldots \ldots$ & Water Turtle,.$\ldots \ldots \ldots \ldots \ldots \ldots \ldots$ \\
\hline
\end{tabular}




\section{LIST OF ILLUSTRATIONS.}

\begin{tabular}{|c|c|c|c|}
\hline & PAGE & & FAGE \\
\hline 1. & Rectangular Tank,........... 19 & 33. & Elegant Chubsucker,.... \\
\hline 2. & Gold Fish,$\ldots \ldots \ldots \ldots \ldots \ldots \ldots . \ldots 1$ & 34. & Gibbous Chubsucker,........ \\
\hline 3. & Brook Trout,,$\ldots \ldots \ldots \ldots \ldots \ldots \ldots .34$ & 35. & Black Cat Fish, ............ \\
\hline 4. & Common Pickerel, $. . \ldots \ldots \ldots \ldots . .25$ & 36. & Brown Cat Fish,.......... \\
\hline 5. & Varied Pickerel,............... 36 & 37. & Common Cat Fish,........ \\
\hline 6. & Buffalo Bony Pike,............. 37 & $3 \mathrm{~S}$. & Common Eel,............. \\
\hline$\tau$. & Champlain Pickering,.......... 38 & 39. & Plain Mud Lamprey Eel,....... 78 \\
\hline & American Yellow Perch, ....... 39 & 40. & Small Lamprey Eel,........... 79 \\
\hline 9. & Rough Yellow Perch,........... 41 & 41. & Two Spined Stickleback,....... 81 \\
\hline 10. & White Perch, $, \ldots \ldots \ldots \ldots \ldots \ldots, 42$ & 42. & New York or Three Spined \\
\hline 11. & Small Black Bass,............. 43 & & Stickleback, $\ldots \ldots \ldots \ldots \ldots . . .63$ \\
\hline 12. & Spineless Perch,............. 44 & 43. & Ten o Many Spined Stickleback, 84 \\
\hline 13. & Fresh Water Bass,........... 45 & 44. & Four Spined Stickleback,....... 85 \\
\hline 14. & Common Sun Fish,.......... 46 & 45. & Transparent Minnow,......... 86 \\
\hline 15. & Black Eared Sun Fish, ........ 48 & 46. & Painted Water Turtle,.......... 99 \\
\hline & Pomotis secludens, $. . . \ldots \ldots \ldots . \ldots 50$ & 47. & Spotted Waıer Turtle,..........102 \\
\hline 17. & Pigmy Dace or Rock Fish, ...... 54 & 48. & Newt or Many Spotted Triton,...103 \\
\hline 18. & $\begin{array}{l}\text { Black Nosed Daced or Striped } \\
\text { Dace, }, \ldots \ldots \ldots \ldots \ldots \ldots \ldots \ldots 6\end{array}$ & $\begin{array}{l}49 . \\
50 .\end{array}$ & $\begin{array}{l}\text { Tiger Triton, } \ldots \ldots \ldots \ldots \ldots \ldots \ldots .105 \\
\text { Black or Dusky Triton, } \ldots \ldots \ldots \ldots 105\end{array}$ \\
\hline 19. & Shining Dace or Shiner,....... 5s & 51. & Red Salamander, ............106 \\
\hline 20. & Banded Dace,$\ldots \ldots \ldots \ldots \ldots \ldots \ldots$. 59 & 52. & American Cray Fish,..........10s \\
\hline 21. & Black Headed Dace,.$\ldots \ldots \ldots$. 60 & 53. & Tadpole of the Common Bull \\
\hline 22. & Spawn Eater,.............. 61 & & Frog,$\ldots \ldots \ldots \ldots \ldots \ldots \ldots$. \\
\hline 23. & Horned Dace or Red Fin,....... 62 & 54. & Tadpole of the Spring Frog,,$\ldots 110$ \\
\hline 24. & Variegated Bream,.$\ldots \ldots \ldots \ldots$. 64 & 55. & Fresh Water Muscle. (Unco \\
\hline 25. & Golden Dace,............... 65 & & complanatus,, .............111 \\
\hline 26. & Pigmy Trout, .............. 66 & 56. & Planorbis trivolvis,............112 \\
\hline 27. & Tessellated Darter,............ 67 & 57. & Physa heterostropha,..........113 \\
\hline 28. & Sheepshead Lebias,........... 68 & 58. & Hydropholis triangularis, ......113 \\
\hline 29. & Little Star Gazer,........... 69 & 59. & Hydropholis ovalis, ...........114 \\
\hline 30. & Pale Sucker,................ 70 & 60. & Hydropholis glaber,...........114 \\
\hline 31. & Horned Sucker,.............. 71 & 61. & Hydropholis lateralis,..........115 \\
\hline 32 & Brilliant Chubsucker,......... 72 & & \\
\hline
\end{tabular}






